\title{
Review \\ FOXM1: A Multifunctional Oncoprotein and Emerging Therapeutic Target in Ovarian Cancer
}

\author{
Cassie Liu, Carter J. Barger and Adam R. Karpf *(D) \\ Eppley Institute and Fred \& Pamela Buffett Cancer Center, University of Nebraska Medical Center, \\ Omaha, NE 68918-6805, USA; cassie.liu@unmc.edu (C.L.); Carter.barger@gmail.com (C.J.B.) \\ * Correspondence: adam.karpf@unmc.edu; Tel.: +1-402-559-6115
}

Citation: Liu, C.; Barger, C.J.; Karpf, A.R. FOXM1: A Multifunctional Oncoprotein and Emerging Therapeutic Target in Ovarian Cancer. Cancers 2021, 13, 3065. https:/ / doi.org/10.3390/cancers13123065

Academic Editor: Katsutoshi Oda

Received: 25 May 2021

Accepted: 16 June 2021

Published: 19 June 2021

Publisher's Note: MDPI stays neutral with regard to jurisdictional claims in published maps and institutional affiliations.

Copyright: (c) 2021 by the authors. Licensee MDPI, Basel, Switzerland. This article is an open access article distributed under the terms and conditions of the Creative Commons Attribution (CC BY) license (https:// creativecommons.org/licenses/by/ $4.0 /)$.
Simple Summary: Ovarian cancer is a lethal disease in women with a 10-year survival rate of $<40 \%$ worldwide. A key molecular alteration in ovarian cancer is the aberrant overexpression and activation of the transcription factor forkhead box M1 (FOXM1). FOXM1 regulates the expression of a multitude of genes that promote cancer, including those that increase the growth, survival, and metastatic spread of cancer cells. Importantly, FOXM1 overexpression is a robust biomarker for poor prognosis in pan-cancer and ovarian cancer. In this review, we first discuss the molecular mechanisms controlling FOXM1 expression and activity, with a specific emphasis on ovarian cancer. We then discuss the evidence for and the manner by which FOXM1 expression promotes aggressive cancer biology. Finally, we discuss the clinical utility of FOXM1, including its potential as a cancer biomarker and as a therapeutic target in ovarian cancer.

Abstract: Forkhead box M1 (FOXM1) is a member of the conserved forkhead box (FOX) transcription factor family. Over the last two decades, FOXM1 has emerged as a multifunctional oncoprotein and a robust biomarker of poor prognosis in many human malignancies. In this review article, we address the current knowledge regarding the mechanisms of regulation and oncogenic functions of FOXM1, particularly in the context of ovarian cancer. FOXM1 and its associated oncogenic transcriptional signature are enriched in $>85 \%$ of ovarian cancer cases and FOXM1 expression and activity can be enhanced by a plethora of genomic, transcriptional, post-transcriptional, and post-translational mechanisms. As a master transcriptional regulator, FOXM1 promotes critical oncogenic phenotypes in ovarian cancer, including: (1) cell proliferation, (2) invasion and metastasis, (3) chemotherapy resistance, (4) cancer stem cell (CSC) properties, (5) genomic instability, and (6) altered cellular metabolism. We additionally discuss the evidence for FOXM1 as a cancer biomarker, describe the rationale for FOXM1 as a cancer therapeutic target, and provide an overview of therapeutic strategies used to target FOXM1 for cancer treatment.

Keywords: FOXM1; forkhead box M1; transcription factors; oncogenes; oncoproteins; ovarian cancer; high-grade serous ovarian cancer

\section{Introduction}

\subsection{FOX Proteins and FOXM1 Discovery}

Forkhead box (FOX) proteins are a family of transcription factors defined by an evolutionarily conserved 80-100 amino acid domain called the forkhead box or wingedhelix motif [1-5]. There are 50 known FOX genes in the human genome divided into 19 subfamilies (A-S) [6]. Sequence variation outside of the shared forkhead box motif leads to diverse mechanisms of regulation and function between FOX subfamilies, and different FOX subfamilies are involved in critical cellular processes and govern organ system functions [7]. For example, the FOXA subfamily participates in cellular metabolism and the development of endoderm-derived organs [8]; the FOXC subfamily promotes blood vessel maturation and lymphatic sprouting [9]; the FOXO subfamily regulates 
cell cycle arrest at G1, apoptosis, and resistance to oxidative and cellular stress [10]; the FOXP subfamily is involved in immune system functions, including coordinating the development and function of $\mathrm{B}$ and $\mathrm{T}$ lymphocytes [11].

FOXM1 is the sole member of the FOXM subfamily [6]. Historically, FOXM1 held alternative names: Trident [12], WIN [13], hepatocyte nuclear factor 3 (HNF3) [14], fork head homolog 11 (HFH-11) [14,15], FKHL16 [15], M-phase phosphoprotein 2 (MPHOSPH2, MPP2) [16], MPM2-reactive phosphoprotein 2 (MPP2) [16], and TGT3 [17]. In 1997, FOXM1 was first identified by Korver et al. as Trident from mouse thymus tissue [12], by Yao et al. as WIN from a rat insulinoma cell line [13], and by Ye et al. as HNF-3/HFH-11 from a human colon carcinoma cell line [14]. These initial studies reported that FOXM1 is widely expressed in embryonic tissues but that its expression is restricted in adult tissues to actively proliferating cells, such as those in the thymus and gastrointestinal tract $[12-14,18]$. Indeed, later studies confirmed that FOXM1 is highly expressed in embryonic [19-22], regenerative [23-26], and cancerous tissues [27-29] and all of them exhibit high proliferative capacity. The FOXM1 field and publications have increased steadily since the year 2000, with a large proportion of studies focused on cancer (Figure 1).

\section{Annual FOXM1 Publications}

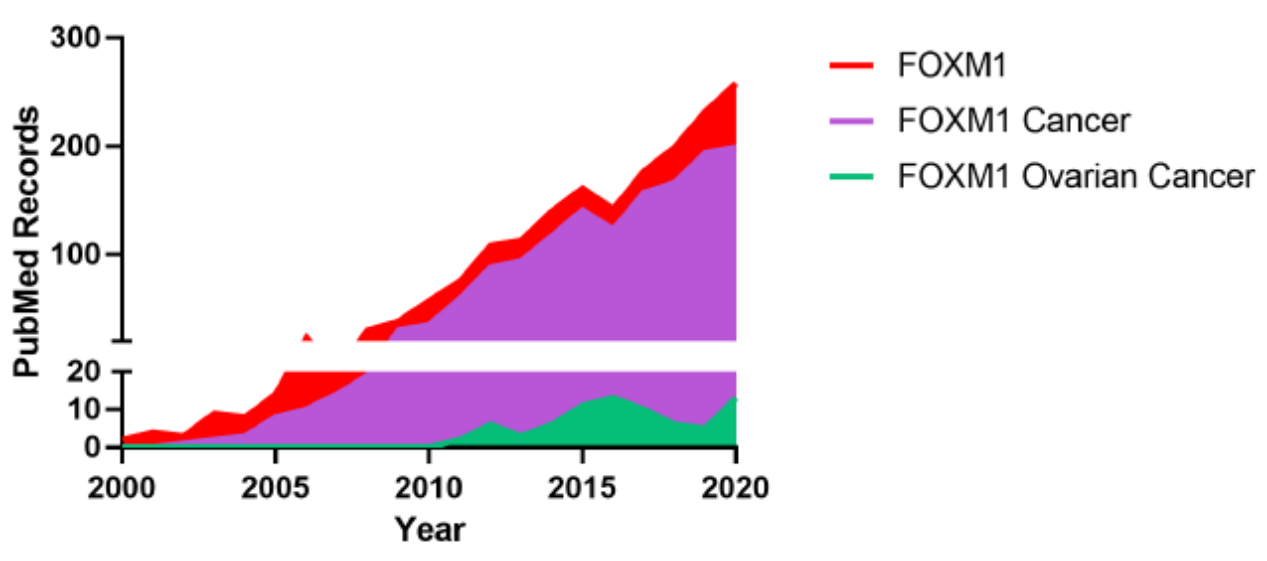

Figure 1. Annual FOXM1 Publications. The data shown were generated from PubMed searches conducted on 04/13/21. The search terms used (all fields) were "FOXM1" (results in red), "FOXM1 cancer" (results in purple), and "FOXM1 ovarian cancer" (results in green). The first "FOXM1 ovarian cancer" PubMed record is the TCGA HGSC study published in 2011 [30].

\subsection{FOXM1 Structure and Transcriptional Activity}

The human FOXM1 gene, located at chromosome 12p13.33, consists of ten exons, including exons I-VIII and alternatively spliced exons Va and VIIa $[13,15,28]$. Exon Va encodes a 15 amino acid insertion into the DNA binding domain (DBD), which is a feature not seen in other FOX family members. On the other hand, exon VIIa encodes a 38 amino acid insertion into the transactivation domain (TAD) [13,14,28]. Alternative splicing of exons Va and VIIa gives rise to three well-characterized FOXM1 isoforms (Table 1): FOXM1a includes all ten exons, FOXM1b omits alternative exons Va and VIIa, and FOXM1c includes alternative exon Va and omits alternative exon VIIa $[13,14,28,29]$. Notably, functional characterizations have shown that FOXM1b and FOXM1c are transcriptionally active while FOXM1a is not $[12,14,27,28,31,32]$. Additional FOXM1 isoforms have also been reported in the literature but have not been well characterized to date (Table 1). 
Table 1. FOXM1 isoforms and variants.

\begin{tabular}{|c|c|c|c|c|c|c|c|}
\hline $\begin{array}{l}\text { Isoform } \\
\text { Name }\end{array}$ & Structure & Known Function & Size & RefSeq ID & Ensembl ID & UniProt ID & References \\
\hline \multicolumn{8}{|c|}{ Well-Characterized FOXM1 Isoforms } \\
\hline FOXM1a & $\begin{array}{l}\text { Includes alternative exons } \\
\text { Va and VIIa }\end{array}$ & Not transcriptionally active & 801 aа & NM_202002 & ENST00000342628 & Q08050-3 & {$[13,14,28,29]$} \\
\hline FOXM1b & $\begin{array}{l}\text { Omits alternative exons } \\
\text { Va and VIIa }\end{array}$ & Transcriptionally active & 748 aа & NM_202003 & ENST00000361953 & Q08050-2 & {$[13,14,28,29]$} \\
\hline FOXM1c & $\begin{array}{c}\text { Includes alternative exon } \\
\text { Va; omits alternative exon } \\
\text { VIIa }\end{array}$ & Transcriptionally active & 763 aа & NM_021953 & ENST00000359843 & Q08050-1 & {$[13,14,28,29]$} \\
\hline \multicolumn{8}{|c|}{ Other Reported FOXM1 Isoforms } \\
\hline FOXM1b1 & $\begin{array}{l}\text { Omits alternative exons } \\
\text { Va and VIIa; omits alanine } \\
\text { residue at the beginning of } \\
\text { exon III; includes } \\
\text { glutamine residue at the } \\
\text { end of exon V } \\
\text { Omits alternative exons }\end{array}$ & $\begin{array}{l}\text { Transcriptionally active with } \\
\text { functions similar to FOXM1b }\end{array}$ & 748 aа & NM_001243088 & ENST00000627656 & A0A0D9SFF0 & [33] \\
\hline FOXM1b2 & $\begin{array}{l}\text { Omits alternative exons } \\
\text { Va and VIIa; omits alanine } \\
\text { residue at the beginning of } \\
\text { exon III }\end{array}$ & $\begin{array}{l}\text { Transcriptionally active with } \\
\text { functions similar to FOXM1b }\end{array}$ & 747 aа & NM_001243089 & $\mathrm{N} / \mathrm{A}$ & $\mathrm{N} / \mathrm{A}$ & [33] \\
\hline FOXM1d & $\begin{array}{l}\text { Includes alternative exon } \\
\text { VIIa; omits alternative } \\
\text { exon Va }\end{array}$ & $\begin{array}{l}\text { Not transcriptionally active; } \\
\text { binds directly to oncogenic } \\
\text { proteins }\end{array}$ & 786 aа & $\mathrm{N} / \mathrm{A}$ & $\mathrm{N} / \mathrm{A}$ & $\begin{array}{l}\text { A0A2P9DTZ0- } \\
1\end{array}$ & {$[31,34,35]$} \\
\hline $\begin{array}{l}\text { FOXM1 } \\
\text { variant } \\
\text { gAug10 }\end{array}$ & $\begin{array}{c}\text { No evidence at the protein } \\
\text { level }\end{array}$ & $\mathrm{N} / \mathrm{A}$ & N/A & $\mathrm{N} / \mathrm{A}$ & ENST00000536066 & $\mathrm{N} / \mathrm{A}$ & {$[36]$} \\
\hline $\begin{array}{l}\text { FOXM1 } \\
\text { variant } \\
\text { lAug10 }\end{array}$ & $\begin{array}{c}\text { No evidence at the protein } \\
\text { level }\end{array}$ & $\mathrm{N} / \mathrm{A}$ & N/A & $\mathrm{N} / \mathrm{A}$ & $\mathrm{N} / \mathrm{A}$ & $\mathrm{N} / \mathrm{A}$ & [36] \\
\hline
\end{tabular}

FOXM1 contains three recognized functional protein domains: (1) a negative regulatory domain (NRD) at the N-terminus, (2) a centrally located DBD, and (3) an acidic TAD at the C-terminus (Figure 2) $[12,15,37,38]$. As a transcription factor, FOXM1 binds DNA within the major groove at promoters containing the canonical forkhead motif RYAAAYA, where $\mathrm{R}=$ purine $(\mathrm{A} / \mathrm{G})$ and $\mathrm{Y}=$ pyrimidine $(\mathrm{C} / \mathrm{T})[12,39]$. FOXM1 appears to bind to its recognition sequence with lower affinity than other FOX family members; this suggests that FOXM1 may utilize more complex mechanisms for DNA binding and gene expression regulation [39]. For example, FOXM1 can be recruited to gene targets by either directly binding Forkhead consensus sequences [40] or indirectly through protein-protein interactions with the MuvB complex (LIN9, LIN37, LIN52, LIN54, and RBBP4) [41,42]. In addition, FOXM1 interaction with MuvB and B-Myb can facilitate FOXM1 binding directly to nonconsensus genomic sequences [41-43]. Recently, an investigation using FOXM1 chromatin immunoprecipitation sequencing (ChIP-Seq) in five cancer cell lines from different organ origins revealed that FOXM1 can interact directly or indirectly with the Nuclear Transcription Factor Y (NFY) complex to regulate the majority of its cell cycle- and mitosis-related gene targets [44]. This study also proposed that FOXM1 may promote cell type-specific gene expression through additional mechanisms, such as binding to super-enhancers and interacting with cell type-specific transcription factors [44]. In agreement, FOXM1 was recently identified as a key transcriptional regulator of cancer-specific enhancers in lung adenocarcinoma [45]. 


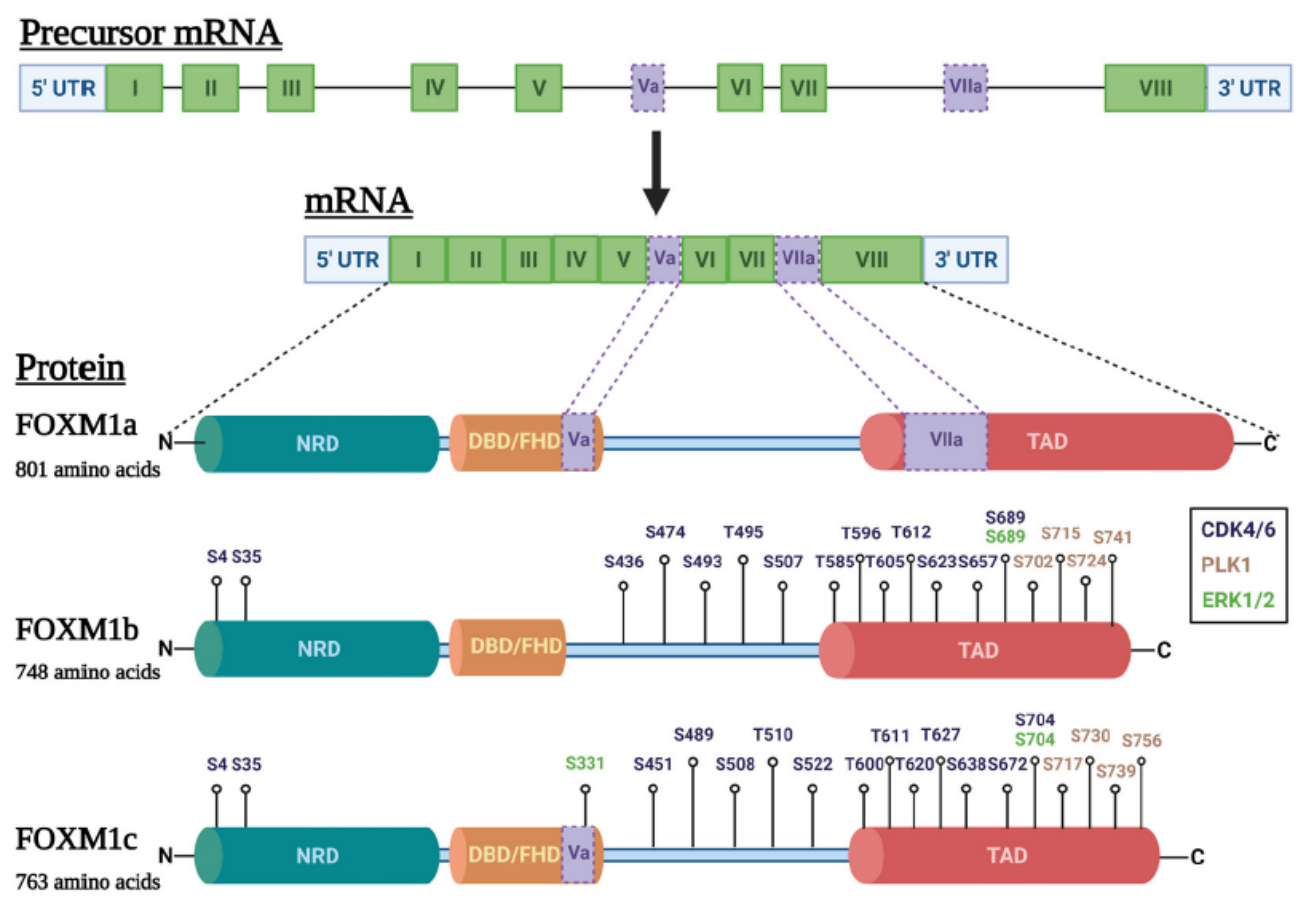

Figure 2. FOXM1 isoforms and phosphorylation sites in ovarian cancer. Top: FOXM1 precursor mRNA (with introns and exons indicated) followed by FOXM1 mRNA structure (exons only). Exons shared by all FOXM1 isoforms are shown in green while alternative exons are shown in light purple. Bottom: Diagram of protein structure of the three major FOXM1 isoforms: (1) FOXM1a, which contains alternative exons Va and VIIa; (2) FOXM1b, which contains no alternative exons; and (3) FOXM1c, which contains alternative exon Va. The three major protein domains are indicated: N-terminal repressor domain (NRD, teal); DNA binding/forkhead domain (DBD/FHD, orange); and transactivation domain (TAD, red). The protein regions corresponding to the alternative exons Va and VIIa are shown in light purple. FOXM1 residues reported to be phosphorylated by three kinases important in ovarian cancer, CDK4/6 (dark blue), PLK1 (tan), and ERK1/2 (green), are indicated. Figure created with BioRender.com.

\subsection{FOXM1 Function and Regulation}

FOXM1 exhibits spatiotemporal expression and activity throughout the cell cycles. FOXM1 mRNA and protein expression increases in late G1-phase, peaks in S-phase, and remains at high levels in G2/M through late $\mathrm{M}$-phase $[12,28,46]$. In addition to regulation at the transcriptional and translational levels, fine-tuning of FOXM1 expression also occurs post-translationally. FOXM1 protein stability is regulated by the E3 ubiquitin ligase complex CRL4 ${ }^{\mathrm{VprBP}}$ in $\mathrm{G}_{1}$-phases and S-phases [47] and by the F-box protein FBXO31 during the $\mathrm{G}_{2}-\mathrm{M}$ transition [48]. Another critical regulator of FOXM1 function is posttranslational modification by phosphorylation. During cell cycle progression, FOXM1 undergoes sequential multi-site phosphorylation by several cyclin-CDK complexes ( $\mathrm{Cy}$ clin D-CDK4/6 [49], Cyclin E-CDK2 [50], and Cyclin A/B-CDK1/2 [51-54]) as well as by other kinases (CHK2 [55], MAPK [56], and PLK1 [57]), all of which facilitate FOXM1 stabilization, nuclear translocation, and activation [29]. Upon mitotic exit, FOXM1 is targeted for ubiquitin-mediated proteasomal degradation by the anaphase promoting complex/cyclosome (APC/C) E3 ubiquitin ligase [58]. Thus, the cycle of FOXM1 expression, phosphorylation, and degradation repeats with every cell division cycle.

The NRD of FOXM1 binds to the TAD to repress FOXM1 transcriptional activity (auto-repression). Importantly, phosphorylation of the TAD relieves self-inhibition from the NRD, which allows for differential activation and gene targeting of FOXM1 at different cell cycle stages $[37,50,52,54,59]$. A recent investigation supports a model where FOXM1 phosphorylation by CDK proteins provides a docking site for polo-like kinase 1 (PLK1), which then phosphorylates the TAD at S730 on FOXM1c (S715 on FOXM1b) and releases it 
from the NRD [59]. The TAD and NRD become structurally disordered upon disassociation and offer flexibility in interacting with binding partners such as p300/CBP [59]. This model may be primarily applicable to FOXM1 activation at the G2/M checkpoint, where PLK1 is known to function. Thus far, no other kinase has been shown to phosphorylate the TAD at S730 on FOXM1c (S715 on FOXM1b).

Once activated, FOXM1 promotes entry into $S$ phase by activating the transcription of genes regulating the G1/S checkpoint (e.g., SKP2 and CKS1) [60]. Later, entry into M phase is mediated by FOXM1 activation of genes regulating the G2/M checkpoint (e.g., PLK1, CDC25B, CCNB1, NEK2, and BIRC5) [60-62]. Finally, FOXM1 promotes faithful mitotic progression by activating genes involved in mitotic spindle assembly and chromosome segregation (e.g., AURKB, KIF20A, CENPA, CENPB, and CENPF) [60-62]. Thus, FOXM1 functions as a critical transcriptional regulator of several important cell cycle transitions, and its ability to differentially activate gene sets may relate both to its sequential phosphorylation as well as the presence of distinct binding partner complexes at different cell cycle phases.

In addition to phosphorylation and ubiquitination, FOXM1 is regulated by other post-translational modifications [29]. Small ubiquitin modifiers (SUMOs) may be necessary for both FOXM1 activation and degradation, depending on the SUMOylation site [63-67]. Acetylation of FOXM1 may promote its activity [68], while methylation of FOXM1 may suppress its activity [69]. SUMOylation, acetylation, and methylation of FOXM1 require further study to discern their relative roles and potential crosstalk in FOXM1 regulation.

\subsection{Transgenic Mouse Models Reveal Functions of FOXM1}

Whole-body knockout of FOXM1 results in embryonic lethality in mice. Foxm1-/mouse embryos with deletion of exons IV-VII, which removes the DBD and TAD, died in utero between E13.5 and E16.5 due to a failure to properly form multiple organs, including the liver, lung, and heart [20-22]. Notably, polyploidy was observed in hepatoblasts and embryonic cardiomyocytes, which likely results from improper mitotic progression [20,22]. Foxm1 $1^{-/-n e o}$ mice, where the PGK-neomycin cassette was inserted into Exon III of Foxm1, died perinatally with increased numbers of polyploid cells in the developing heart and liver, which is a phenomenon observed as early as E13 [70]. Thus, whole-body knockout revealed the importance of FOXM1 expression in early organogenesis due to the lethal phenotypes observed. These models did not allow investigation of post-embryonic functions of FOXM1.

Conditional Foxm1 knockout (cKO) mice have been used to investigate the role of FOXM1 in tissue-specific organogenesis [71]. For example, Foxm1 deletion in smooth muscle cells did not influence cell differentiation but, rather, decreased proliferation of smooth muscle cells in blood vessels and the esophagus [72]. Deletion of Foxm1 in respiratory epithelial cells prenatally impaired important lung functions (sacculation, type I cell differentiation, and surfactant production) but did not alter gross lung morphology [73]. Conversely, postnatal expression of constitutively active FOXM1b in respiratory epithelial cells increased Clara cell proliferation and airway hyperplasia [74]. Deletion of Foxm1 in pancreatic tissue resulted in a normal pancreas at birth but with a lack of $\beta$-cell mass expansion postnatally, which can result in impaired islet function and overt diabetes [75].

Transgenic mouse models have also been utilized to investigate the roles of FOXM1 in organ regeneration in adult tissues [71]. In response to vascular injury, mice with Foxm1 cKO in endothelial cells showed difficulty reannealing adherens junctions, microvessel leakage, and poor endothelial barrier function [76,77]. In the setting of liver regeneration, hepatocyte-specific Foxm1 deletion slowed hepatocyte proliferation [78], while hepatocytespecific FOXM1b overexpression led to accelerated hepatocyte growth through increased S-phase and M-phase transitions $[46,79,80]$. In mice challenged by lung injury, FOXM1b overexpression increased the proliferation of several cell types in the lung [81], while pancreas-wide Foxm1 deletion [82] and Foxm1 deletion in muscle satellite cells [26] led to impairments in pancreas and muscle repair, respectively, following injury. Collectively, studies using transgenic mice with Foxm1 KO, Foxm $1 \mathrm{cKO}$, and FOXM1b overexpression 
verify an important role for FOXM1 in embryogenesis, organogenesis, and organ regeneration in adults.

Transgenic mouse models have also been utilized to define the functions of FOXM1 in cancer [71]. FOXM1 overexpression in all cell types through a Rosa26-FOXM1b construct, when used in combination with a second tumor induction stimulus or oncogene, increased the number and size of lung adenomas [83]; increased the number, size, and proliferation of colon adenocarcinomas [84]; and accelerated the development of prostate adenocarcinomas [85]. In a transgenic mouse model expressing a constitutively active form of FOXM1b (FOXM1- $\Delta N)$, FOXM1 stimulated progression from urethane-induced benign lung adenomas to invasive metastatic lung adenocarcinomas [86]. However, in instances where FOXM1 was tested as the main tumor inducer (i.e., without a second tumor induction stimulus or oncogene), FOXM1b overexpression alone was insufficient to generate hepatocellular carcinoma [87] and lung adenocarcinoma [74]. Deletion of Foxm1 prior to or following a tumor induction stimulus in mice decreased both the number and size of tumors in the lung [88,89], liver [90], and colon [84]. Interestingly, although FOXM1 overexpression alone appears to be insufficient in driving tumorigenesis in vivo, the absence of FOXM1 prevented tumor development in the colon [84] and liver [91]. These data suggest that FOXM1 is necessary but not sufficient for tumorigenesis in vivo.

To date, transgenic mouse models have not been utilized to interrogate the oncogenic function of FOXM1 in ovarian cancer. This is partially due to the relative dearth of transgenic ovarian cancer models. However, given the recent development of such models [92-94], this is an area that is ripe for future investigations.

\section{Ovarian Cancer}

Ovarian cancer is the fifth leading cause of cancer-related deaths in women in the United States [95] and the eighth leading cause of cancer-related deaths in women globally [96]. Due to the internal location of the ovaries and non-specific symptoms during early-stage disease, ovarian cancer is difficult to detect early on and is frequently diagnosed during the advanced clinical stages (III and IV) [97]. The standard of care treatment for ovarian cancer is cytoreductive (debulking) surgery, platinum-based and taxane combination chemotherapy, and maintenance therapy using poly (ADP-ribose) polymerase inhibitors (PARPi) and/or bevacizumab (an inhibitor of vascular endothelial growth factor (VEGF)) $[98,99]$. However, $>80 \%$ advanced-stage ovarian cancer eventually recurs and treatment with further therapy is palliative [100]; this results in a 10-year overall survival of $<40 \%$ worldwide $[101,102]$. The lethality of ovarian cancer highlights the need to develop better early detection modalities and more effective therapies for relapsed patients.

There are three major categories of ovarian cancer: epithelial (EOC), germ cell, and sex cord-stromal [100]. Of these, EOC comprises $~ 90 \%$ of all ovarian cancer cases [100] and is the focus of this review article. EOC is subtyped by histology into serous (low-grade or high-grade), endometroid, mucinous, and clear cell tumors [100]. Ovarian tumors with serous histology constitute $\sim 70 \%$ of EOC, with most cases being high-grade serous carcinoma (HGSC) [103]. Furthermore, HGSC accounts for up to $90 \%$ of ovarian cancerrelated deaths overall [104]. Although HGSC was traditionally thought to arise from the ovarian surface epithelium (OSE), a majority of the evidence now supports the contention that the fallopian tube epithelium (FTE) is the origin of most HGSC [105-107]. Notably, crucial studies identified HGSC precursors, mainly serous tubal intraepithelial carcinomas (STICs), in the fallopian tubes (FT) of women with disseminated HGSC [108-111] and in those at high risk for developing HGSC (e.g., BRCA1/2 mutation carriers) [112-114].

The prevailing model for HGSC development proposes that normal FTE transforms into early serous proliferations (ESPs) and then STICs, which ultimately become HGSC that disseminate to the ovaries and/or other sites in the peritoneal cavity [105]. Accordingly, ESPs, also known as "p53 signature" lesions, show increased expression of mutant p53 and $\gamma$-H2AX (an indicator of DNA damage) compared to normal FTE [112,115]. STICs show an atypical morphology in addition to the high expression of mutant p53, $\gamma-\mathrm{H} 2 \mathrm{AX}$, and 
Ki-67 (an indicator of proliferative activity) [112,115]. HGSC maintains high expression of mutant p53, $\gamma-\mathrm{H} 2 \mathrm{AX}$, and $\mathrm{Ki}-67$ and experiences profound genomic instability with recurrently altered pathways, including $\mathrm{p} 53, \mathrm{Rb} / \mathrm{E} 2 \mathrm{~F}$, homologous recombination (HR) DNA repair, PI3K/RAS, NOTCH, and FOXM1 [30,115,116].

\section{FOXM1 Is Overexpressed and Activated in Ovarian Cancer}

In 2011, The Cancer Genome Atlas (TCGA) published an integrated genomic analysis of primary HGSC tumors. This landmark study identified FOXM1 as a key oncoprotein in ovarian cancer [30]. The FOXM1 transcriptional pathway was aberrantly activated in over $85 \%$ of cases and rendered it the second most frequent molecular alteration in HGSC, second only to TP53 mutations [30]. Publications on FOXM1 in ovarian cancer have subsequently increased since 2011 (Figure 1). Supporting the initial conclusions of the TCGA, other studies have described widespread overexpression of FOXM1 and its transcriptional targets in HGSC and EOC and have explored the molecular mechanisms underlying FOXM1 pathway activation. These mechanisms are described in detail below and are summarized in Figure 3.

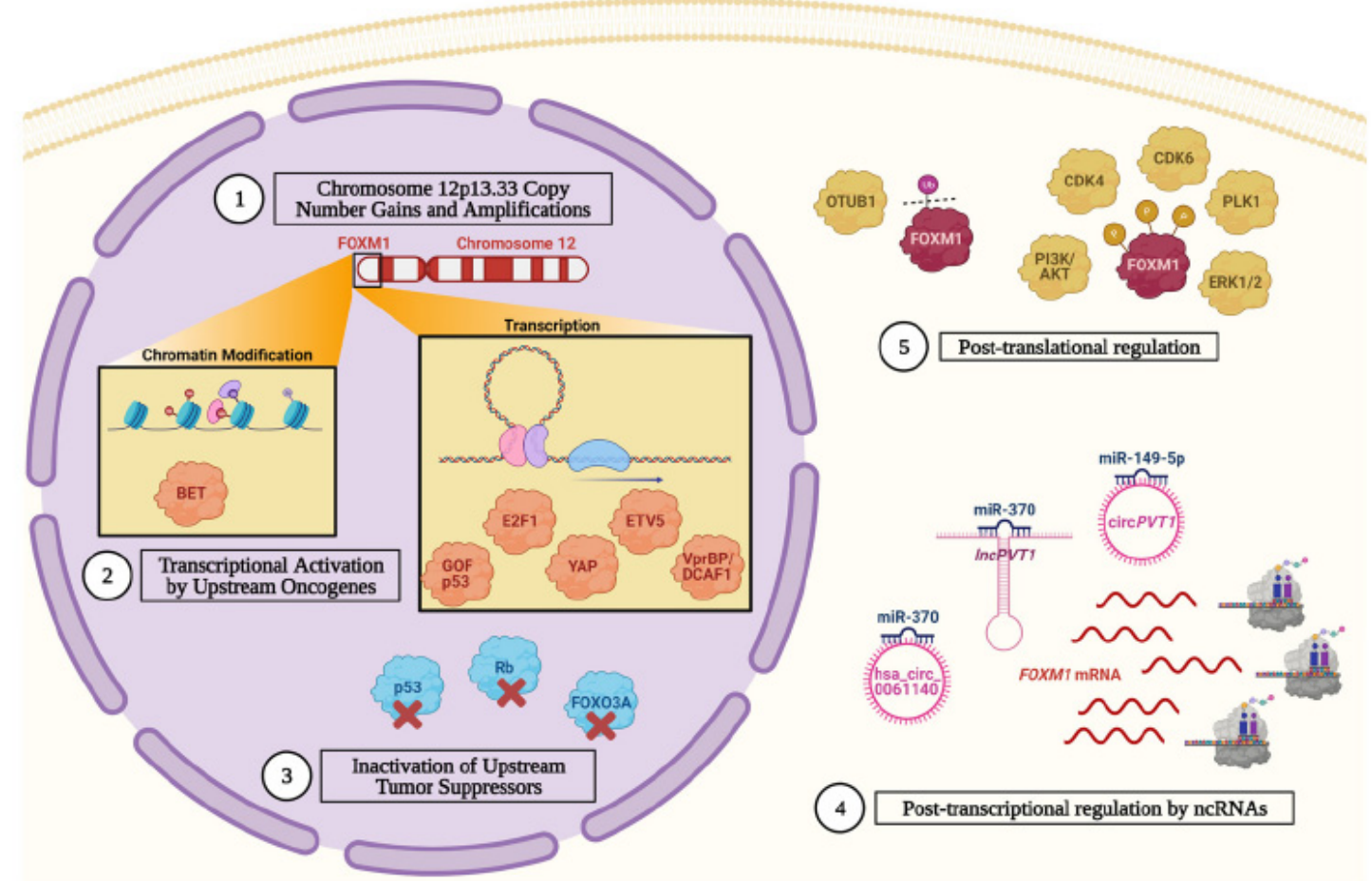

Figure 3. Mechanisms leading to FOXM1 overexpression and activation in ovarian cancer. Several mechanisms that are known to result in FOXM1 overexpression and/or activation in ovarian cancer are shown: (1) Chromosome 12p13.33, where the FOXM1 gene resides, experiences copy number gains and amplifications. (2) Upstream oncogenes (BET, GOF p53, E2F1, YAP, VprBPDCAF1, and ETV5) are overexpressed and upregulate FOXM1 transcription through chromatin modification and promoter activation. (3) Upstream tumor suppressors that regulate FOXM1 transcription (p53, Rb, and FOXO3A) experience inactivation through gene mutation or loss. (4) Post-transcriptional regulation by ncRNAs allow ribosomes to translate high levels of FOXM1 mRNA miR-370 and miR-149-5p, which typically destabilize FOXM1 mRNA, are sponged by lncPVT1, circPVT1, and hsa_circ_0061140. (5) Post-translation regulation stabilizes and activates FOXM1 protein. OTUB1 deubiquitinates FOXM1 and increases protein stability. PI3K/AKT, CDK4, CDK6, PLK1, and ERK1/2 phosphorylate FOXM1, which activates its transcription factor function. Figure created with BioRender.com. 


\subsection{The FOXM1 Gene Experiences Copy Number Gains and Amplifications}

Chromosome 12p13.33, where FOXM1 resides, shows copy number gains and amplifications in many human cancers, and studies indicate that this somatic copy number alteration (SCNA) can occur early in cancer development [117-126]. We reported that, in TCGA data, $45 \%$ of HGSC harbored low-level copy number gain of FOXM1, while $12 \%$ of tumors harbored high-level amplification, impacting almost $60 \%$ of cases [127]. Importantly, FOXM1 copy number correlated with mRNA expression in HGSC and this demonstrates that FOXM1 copy number gain is a functional SCNA [127]. In agreement, we more recently showed that FOXM1 copy number correlates with FOXM1 mRNA and protein expression in pan-cancer [27]. The 12p13.33 amplifications were reported to be common in an independent cohort of HGSC patients before and after front-line chemotherapy (and detectable in plasma), further supporting this mechanism [128]. Despite the high frequency of FOXM1 SCNA observed in HGSC, an even greater proportion of tumors show FOXM1 overexpression or pathway activation (reaching 90\% of HGSC cases) [30,127], indicating that additional mechanisms contribute to FOXM1 overexpression and pathway activation in HGSC.

\subsection{Inactivation of Upstream Tumor Suppressor Promotes FOXM1 Gene Expression}

The TP53 mutations are ubiquitous in HGSC [30,129]. Mutations in TP53 frequently manifest as single base-pair mutations localized to the DBD, resulting in either partial or complete loss of function (LOF) or gain-of-function (GOF) [130]. GOF p53 mutants exhibit both loss of wild-type and gain of oncogenic functions, leading to the promotion of cell proliferation, survival, migration, invasion, and angiogenesis [130,131]. Important early studies revealed wild-type p53 as a negative regulator of FOXM1 [132,133]. In HGSC, bioinformatic pathway prediction suggested that dysfunctional p53 is linked to the upregulation of FOXM1, VEGFA, TPX2, BRIC5, and TOP2A [134]. Moreover, GOF $\mathrm{p} 53^{\mathrm{R} 273 \mathrm{H}}$ and $\mathrm{p} 53^{\mathrm{R} 248 \mathrm{~W} / \mathrm{Q}}$, which are three of the most common $\mathrm{p} 53$ mutations in ovarian cancer $[130,131]$, were noted to dramatically increase FOXM1 protein expression in murine oviductal epithelial cells [135] and human EOC cell lines [136]. Importantly, p53 ${ }^{\mathrm{R} 273 \mathrm{H}}$ and $\mathrm{p} 53^{\mathrm{R} 248 \mathrm{~W}}$ induced distinct levels of FOXM1 protein, suggesting a more complex mechanism than a simple loss of wild-type function [135]. While GOF $\mathrm{p}^{\mathrm{R}}{ }^{\mathrm{R} 175}$ and $\mathrm{p} 53^{\mathrm{Y} 220}$ are also common ovarian cancer TP53 mutations, their relationship with FOXM1 expression has not been established [130].

Paired box transcription factor 8 (PAX8) is an FTE lineage marker that is retained during malignant transformation to STICs and HGSC [92] and appears partially responsible for FOXM1 upregulation in HGSC [137]. In cells of the Müllerian (female genital tract) lineage, PAX8 increased TP53 gene expression regardless of TP53 mutational status [138]. Since nearly all HGSC cases contain mutant p53, it is plausible that PAX8 upregulates FOXM1 expression in a subset of HGSC by enhancing the expression of GOF p53.

One mechanism by which GOF p53 increases FOXM1 expression in EOC is by enhancing FOXM1 mRNA stability [136]. Other GOF p53 mutations, such as p53 ${ }^{\mathrm{G} 245 \mathrm{D}}$, have been shown to upregulate FOXM1 expression in other cancers [139]. Specifically, p53G245D decreased AMP-activated protein kinase (AMPK)-mediated phosphorylation of FOXO3A in head and neck squamous cell carcinoma cells, thereby alleviating its repression on FOXM1 gene expression [139]. Thus, upregulation of FOXM1 expression in ovarian cancer may occur through distinct mechanisms depending on the specific TP53 mutation.

Inactivation of retinoblastoma $(\mathrm{Rb})(\mathrm{RB} 1)$ by truncating point mutations, indels, and gene breakage occurs in $17.5 \%$ of HGSC tumors [116]. Moreover, the Rb pathway is altered in $67 \%$ of HGSC tumors, rendering it a very common molecular defect [30]. In addition, the $\mathrm{Rb}$ and p53 signaling pathways are highly interconnected [140]. In a murine oviductal line continually passaged in culture to mimic cellular aging, high passage number cells demonstrated molecular changes including increased FOXM1 expression, hyper-phosphorylated (i.e, inactivated) $\mathrm{Rb}$, and the expression of a p53 splice variant that exhibited partial loss of wild-type p53 function with potential GOF [141]. Our studies demonstrated that combined 
TP53 and RB1 inactivation in murine and human OSE cells synergistically upregulates FOXM1 mRNA and protein expression than when compared to inactivation of either tumor suppressor alone [127]. Moreover, we showed that FOXM1 is overexpressed in a transgenic murine model of ovarian cancer driven by combined Rb1/Trp53 knockout in the OSE [127]. Downregulation or inactivation of the p53 and $\mathrm{Rb}$ pathways result in the activation of the E2F1 transcription factor, which directly upregulates FOXM1 gene expression by binding to its promoter $[133,142-145]$. Indeed, we reported that E2F1 knockdown in human OSE cells and in the HGSC cell line COV362 with inactivated p53 and Rb significantly reduced FOXM1 mRNA expression [127]. In agreement, E2F1 mRNA showed a strong positive correlation with FOXM1 mRNA in human primary EOC [127]. We also have shown that dysregulation of the $\mathrm{Rb} / \mathrm{E} 2 \mathrm{~F}$ pathway, including the overexpression of E2F1 or cyclin $\mathrm{E} 1$ or RB1 knockout, caused increased FOXM1 expression in FTE cells [27]. TP53 mutation, RB1 copy number loss, and CCNE1 expression each strongly correlates with FOXM1 expression and FOXM1 pathway activation in pan-cancer [27]. These findings establish that p53 and $\mathrm{Rb}$ pathway dysregulation is a key contributor to FOXM1 overexpression in ovarian cancer.

FOXO3A is a FOX family member and tumor suppressor that functions as a negative regulator of FOXM1. FOXO3A suppresses FOXM1 activity via at least three mechanisms: (1) Downregulating FOXM1 gene expression, potentially through the upregulation of the Mad/Max family of transcriptional repressors [146-148]; (2) directly displacing FOXM1 from the promoter region of FOXM1 target genes [148-150]; and (3) condensing FOXM1 gene targets into heterochromatin, making the genes less accessible to FOXM1-mediated activation [148]. Critically, as normal FTE progresses to STIC lesions and HGSC, FOXO3A expression steadily decreases with a concurrent increase in FOXM1 expression and activation of the PI3K/AKT and MAPK/ERK pathways [151]. Several mechanisms may result in the loss of FOXO3A expression in HGSC. First, late-stage HGSC tumors demonstrated FOXO3A copy number loss and a subset of TCGA HGSC showed upregulation of miR-182, which targets FOXO3A mRNA for degradation [151]. Second, FOXO3A phosphorylation by the PI3K/AKT or MAPK/ERK pathways, which are highly active in HGSC, results in the nuclear export of FOXO3A to the cytoplasm and thus inactivation of its transcriptional activity $[151,152]$. Third, T-type $\mathrm{Ca}^{2+}$ channels, which are aberrantly overexpressed in ovarian cancer, can activate the PI3K/AKT pathway, thus antagonizing FOXO3A nuclear retention and promoting FOXM1 expression [153]. Consequently, selective inhibitors against PI3K, ERK1/2, and AKT were shown to significantly decrease both basal and induced FOXM1 gene expression levels in HGSC cells [154]. In agreement, inhibiting T-Like Cell-Originated Protein Kinase (TOPK), which is a protein in the MAPK/ERK pathway that also modulates the PI3K/AKT pathway, leads to decreased FOXM1 gene expression in ovarian cancer cells [155].

\subsection{Upstream Oncogenes Promote FOXM1 Expression}

Several oncogenic transcription factors have been noted to promote FOXM1 overexpression in ovarian cancer. Yes-associated protein (YAP) can bind to the FOXM1 promoter and promotes FOXM1 gene expression in HGSC cell lines [154]. Investigations in mesothelioma and soft-tissue sarcoma cell lines have also demonstrated the ability of the YAP-TEAD complex to transcriptionally activate FOXM1 expression [156,157], and there is evidence in soft-tissue sarcoma that FOXM1 can directly interact with the YAP-TEAD complex to promote cell proliferation [157]. In HGSC, bromodomain and extraterminal domain (BET) proteins recognize acetylated lysine residues on histones and may recruit chromatinmodification enzymes or co-activators to activate the FOXM1 promoter [158]. Indeed, a pan-inhibitor of the BET family, I-BET151, downregulated FOXM1 mRNA and protein expression in several EOC cell lines [159]. Given the emergence of BET inhibitors as a novel therapeutic approach in EOC [160], further studies of the effect of these agents on FOXM1 expression and FOXM1-driven phenotypes are warranted. Additional proteins, which are not classical oncogenes, are also known to upregulate FOXM1 expression in ovarian cancer. For example, the ETS family transcription factor ETV5 directly binds to the FOXM1 
promoter to upregulate its expression in EOC [161]. Additionally, the E3 ubiquitin ligase substrate receptor VprBP/DCAF1, which is upregulated in HGSC, co-activates FOXM1 expression by a mechanism independent of its E3 ubiquitin ligase activity [47].

Studies in other cancer types have identified well-known oncogenic transcription factors that bind to the FOXM1 promoter and induces its transcription: Gli1 and Gli2 in the sonic hedgehog (Shh) pathway [162-165], c-Myc [145,166-168], STAT3 [169], and Twist1 [170]. cMyc is known to transcriptionally activate FOXM1 in several cancers [166-168] and, notably, exhibits copy number gains in $>65 \%$ of HGSC cases [30]. In addition, FOXM1 has been reported to bind to its own promoter and induce its own gene expression through an autoregulatory circuit [171,172]. However, our data were unable to confirm this mechanism [27].

Although not addressed in ovarian cancer, there is evidence that stress response proteins increase FOXM1 expression; this suggests that FOXM1 promotes cell survival in harsh conditions. For example, heatshock factor 1 (HSF1) can bind to the FOXM1 promoter and upregulate its expression when glioma cells are subjected to lethal heat shock stress [173]. Activating transcription factor 4 (ATF4), which is a transcriptional regulator that responds to amino acid deprivation, can upregulate histone lysine demethylase KDM4C, which activates transcription of FOXM1 and FOXM1 target genes [174].

Reactive oxygen species (ROS) provide another link between cell stress and FOXM1. ROS can upregulate FOXM1 expression, which then activates transcription of ROS scavenger proteins such as manganese superoxide dismutase (MnSOD) [175]. MnSOD in turn promotes E2F1-mediated and Sp1-mediated activation of the FOXM1 promoter [176]. These findings suggest that ROS activates a feed forward loop that leads to the increased protein expression of MnSOD and FOXM1. Additionally, HIF1 $\alpha$, in the presence of ROS or hypoxia, binds to and transactivates the FOXM1 promoter $[177,178]$. In the context of ovarian cancer, the follicular fluid microenvironment is a major source of ROS, which plays important physiologic functions in the ovaries, including follicular growth, oocyte maturation, and ovarian steroid biosynthesis [179]. The oxidative stress exerted on the ovaries and FT could potentially result in FOXM1 upregulation in premalignant and malignant ovarian cells, which may in turn drive cellular proliferation in cells that might normally undergo DNA damage arrest.

\subsection{FOXM1 Is Post-Transcriptionally Regulated by Non-Coding RNAs (ncRNA)}

Non-coding RNAs (ncRNA) compose a complex regulatory network that participates in diverse biological processes ranging from chromatin remodeling to protein stabilization $[180,181]$. In the context of FOXM1, ncRNA investigations have focused on posttranscriptional regulation of the FOXM1 mRNA. Among the different classes of ncRNAs, microRNAs (miRNA) bind to and destabilize messenger RNAs (mRNA), while long noncoding RNAs (lncRNA) and circular RNAs (circRNA) can contain miRNA-complementary sites that competitively bind to miRNAs and reduce the number of available miRNAs that can bind to mRNA targets; this is an action known as miRNA sponging [180,181]. Thus, ncRNAs play a major role in FOXM1 regulation, with over 40 implicated to date [182].

In ovarian cancer, miR-370 targets FOXM1 mRNA for degradation [183,184]. This mechanism has also been observed in osteosarcoma [185], gastric cancer [186], and acute myeloid leukemia [187]. CircRNA hsa_circ_0061140 and lncRNA plasmacytoma variant translocation 1 (lncPVT1), for which expressions are upregulated in ovarian cancer, sponge miR-370 activity in ovarian cancer cells $[183,184]$. Studies in gastric cancer and pan-cancer have suggested that $\operatorname{lnc} P V T 1$ can also interact with and stabilize the FOXM1 protein and have shown that FOXM1 binds to the promoter of $\operatorname{lnc} P V T 1$ to activate its transcription [188,189]. Additionally, lncPVT1 can interact with FOXM1 mRNA directly, potentially regulating FOXM1 mRNA splicing and stability [189]. PVT1 also exists as a circRNA (circPVT1) [190]. In EOC, circPVT1 is able to sponge miR-149-5p, which targets FOXM1 mRNA [191]. miR-149 has also been shown to repress FOXM1 expression in non-small-cell lung cancer [192] and gastric cancer [193]. Interestingly, PVT1 is located on chromosome band 8q24.21 and is frequently co-amplified with MYC [30,194]. Additional 
miRNAs established to target FOXM1 in ovarian cancer are miR-134 [195-199] and miR216b [200-203]. Interestingly, a recent report indicates that FOXM1 acts as a transcriptional regulator of several miRNA molecules in triple-negative breast cancer, which has a similar molecular profile to HGSC [204]. Taken together, these data indicate that ncRNA alterations play a key role in promoting FOXM1 expression in cancer, including ovarian cancer, and that FOXM1 itself can function in miRNA dysregulation.

\subsection{FOXM1 Is Stabilized and Activated by Post-Translational Mechanisms}

As mentioned earlier, FOXM1 is functionally regulated by post-translational modifications (PTMs). In particular, a plethora of evidence supports that FOXM1 protein stabilization and transcriptional activity depend on specific phosphorylation events [29,37,49-57,59]. However, to date, most FOXM1 expression studies in cancer, including ovarian cancer, have only reported overall FOXM1 protein levels rather than phosphorylated FOXM1 (phosphoFOXM1), which stems from a limited number of antibodies available for PTMs. Measuring phospho-FOXM1 may provide more insight into FOXM1 activation status in cancer and should be emphasized in future investigations. Known FOXM1 phosphorylation sites of kinases known to be relevant in ovarian cancer are illustrated in Figure 2.

The MAPK/ERK and PI3K/AKT pathways promote FOXM1 activation in cancer, including ovarian cancer. As described earlier, the overabundance of T-type $\mathrm{Ca}^{2+}$ channels in ovarian cancer leads to PI3K/AKT overexpression and, consequently, treatment with mibefradil, which is a calcium channel blocking agent, decreased nuclear FOXM1 protein levels and its binding to the BIRC5 (survivin) promoter in EOC cells [153]. Growth factor receptor-bound protein 7 (GRB7), which is a signal transducing adaptor protein that is overexpressed in ovarian cancer, promotes constitutive activation of the MAPK/ERK pathway and thereby leads to enhanced FOXM1 activity [205]. Interestingly, the MEK inhibitor U0126 decreased FOXM1 protein levels in OVCA433, which is an ovarian cancer cell line with functional p53, but not in SKOV3, a p53-deleted ovarian cancer cell line; this suggests that functional p53 may be necessary for the MAPK/ERK pathway to regulate FOXM1 activity [206]. Studies in other cancers have suggested that the PI3K/AKT pathway, independent of the MAPK/ERK pathway, functions as a main activator of oncogenic FOXM1 activity [207-209].

Additional kinases also promote FOXM1 phosphorylation in ovarian cancer. HGSC tumors with downregulation of miR-506, which targets CDK4/6 mRNA, showed increased FOXM1 protein [210]. Since CDK4/6 phosphorylates FOXM1c at numerous residues (Figure 2) [49], this result implies that the gain of CDK4/6 increased FOXM1 protein activity and stability in these tumors. Overexpression of Polo-like kinase 1 (PLK1), for which phosphorylation at S730 at the TAD of FOXM1c (S715 on FOXM1b) relieves the physical repression of the FOXM1 NRD [59], is prognostic for poor overall survival in EOC [211,212]. Elucidating the relative contributions of different kinases to FOXM1 activation in ovarian cancer may provide novel avenues for therapeutic intervention in this disease.

Deubiquitination serves as an additional mechanism to increase FOXM1 expression in ovarian cancer. Otubain 1 (OTUB1) belongs to a family of deubiquitinases (DUBs), for which their defining feature is their ovarian tumor (OTU) domain, and OTUB1 promotes aggressive behavior in several cancers through both canonical and non-canonical DUB functions [213]. In ovarian cancer, OTUB1 promoted ovarian cancer cell proliferation, invasion, and tumor growth through deubiquitination and stabilization of FOXM1 [214]. It is likely that other DUBs may stabilize FOXM1 protein in ovarian cancer. For example, in basal breast cancer, which has robust molecular similarity to HGSC [215], the DUB USP21 deubiquitinates and stabilizes FOXM1 in vitro and in vivo [216]. Further elucidations of DUBs that target FOXM1 in ovarian cancer are an important area for future investigations.

\section{FOXM1 Oncogenic Functions}

FOXM1 is a transcriptional master regulator of several hallmarks of cancer $[217,218]$. Upregulation and activation of FOXM1 in cancer can contribute to numerous phenotypes, 
including cell proliferation, cancer stemness, genomic instability, drug resistance, protection from oxidative stress, altered metabolism, invasion, metastasis, angiogenesis, and inflammation $[148,217,219,220]$. Remarkably, and consistent with its function in a myriad of oncogenic phenotypes, FOXM1 has been reported as the top gene expression biomarker for poor prognosis in a pan-cancer analysis consisting of $>18,000$ tumors from 39 distinct malignancies [221]. Our present understanding of FOXM1 in relation to ovarian cancer phenotypes is summarized in Figure 4. Mechanistically, FOXM1 activates genes by binding to gene promoters and enhancers, both directly [40] and via interactions with transcription factor complexes such as MuvB [41-43], B-Myb [41-43], and NFY [44]. FOXM1 transcriptional targets identified in ovarian cancer are shown in Table 2.

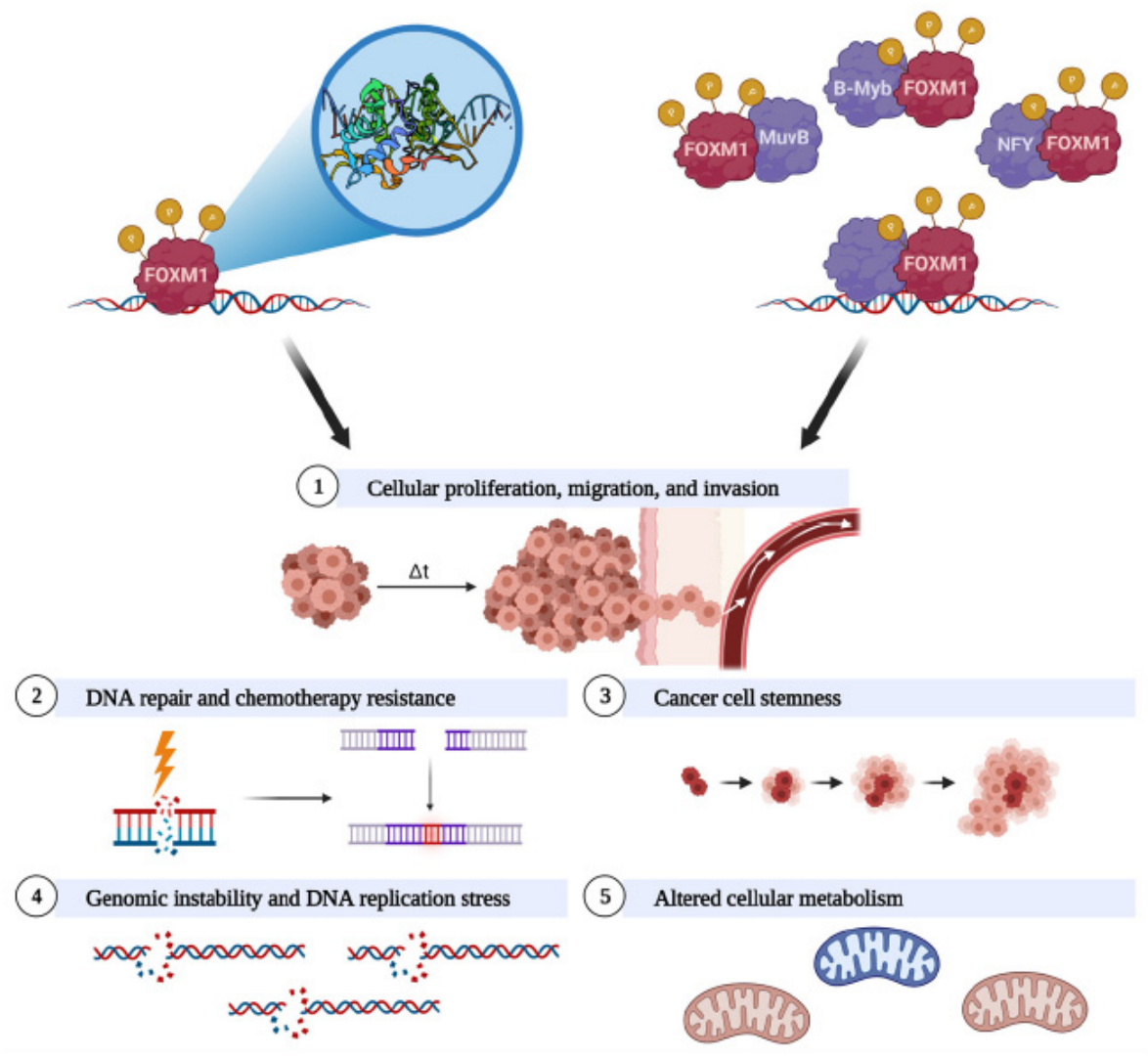

Figure 4. The oncogenic functions of FOXM1 in ovarian cancer. FOXM1 transactivates genes by binding to gene enhancers and promoters, either directly through its DNA binding domain (DBD) or indirectly by interacting with other transcription factors (B-Myb, MuvB, and NFY). Through these two mechanisms, FOXM1 has been shown to promote several oncogenic phenotypes in ovarian cancer, including: (1) cellular proliferation, migration, and invasion; (2) DNA repair and chemotherapy resistance; (3) cancer cell stemness; (4) genomic instability and DNA replication stress; (5) altered cellular metabolism. Figure created with BioRender.com. 
Table 2. FOXM1 target genes and their functions.

\begin{tabular}{|c|c|c|}
\hline FOXM1 Target (Gene) & Known Oncogenic Mechanism & References \\
\hline \multicolumn{3}{|c|}{ Cellular Proliferation } \\
\hline Cyclin B1 (CCNB1) & Cyclin protein that promotes mitosis & {$[127,222]$} \\
\hline S-phase kinase-associated protein 2 (SKP2) & $\begin{array}{l}\text { F-box protein that mediates cell cycle entry and } \\
\text { G1/S transitions }\end{array}$ & {$[127]$} \\
\hline Polo-like kinase 1 (PLK1) & $\begin{array}{c}\text { Protein kinase that mediates mitosis and } \\
\text { cytokinesis }\end{array}$ & [127] \\
\hline Cell division cycle $25 \mathrm{~B}(C D C 25 B)$ & $\begin{array}{l}\text { Tyrosine protein phosphatase that mediates cell } \\
\text { cycle progression and mitosis }\end{array}$ & [222] \\
\hline Centrosomal protein 55 (CEP55) & Mitotic phosphoprotein that mediates cytokinesis & [222] \\
\hline Centrometere protein $\mathrm{F}(C E N P F)$ & $\begin{array}{l}\text { Microtubule-binding protein and mediates cell } \\
\text { division }\end{array}$ & [222] \\
\hline DNA topoisomerase II Alpha (TOP2A) & $\begin{array}{l}\text { DNA topoisomerase that mediates DNA } \\
\text { transcription and replication and chromosome } \\
\text { condensation and segregation }\end{array}$ & [222] \\
\hline Cyclin F (CCNF) & $\begin{array}{l}\text { F-box protein that mediates the stability of proteins } \\
\text { that regulate cell cycle and genome stability } \\
\text { Microtubule-associated protein essential for }\end{array}$ & [223] \\
\hline Protein regulator of cytokinesis 1 (PRC1) & $\begin{array}{c}\text { cytokinesis (related to mitosis-related genes in } \\
\text { ovarian cancer) }\end{array}$ & [223] \\
\hline Homeobox DLX-1 (DLX1) & $\begin{array}{l}\text { Transcription factor that modulates the } \\
\text { TGF- } \beta 1 / \text { SMAD4 signaling pathway in ovarian } \\
\text { cancer }\end{array}$ & [224] \\
\hline $\begin{array}{l}\text { Proliferation cell nuclear antigen clamp-associated } \\
\text { factor (PCLAF) }\end{array}$ & $\begin{array}{l}\text { PCNA-binding protein that regulates DNA repair, } \\
\text { cell cycle progression, and proliferation (and } \\
\text { activates the PI3K/AKT/mTOR signaling } \\
\text { pathways in ovarian cancer) }\end{array}$ & [225] \\
\hline Kinesin-like protein KIF20A (KIF20A) & $\begin{array}{l}\text { Kinesin protein that participates in cytokinesis and } \\
\text { intracellular transportation }\end{array}$ & [223] \\
\hline
\end{tabular}

Cellular Migration and Invasion

Cyclin F (CCNF)

Protein regulator of cytokinesis 1 (PRC1)

Matrix metalloproteinase 2 (MMP2)

Homeobox DLX-1 (DLX1)

Proliferation cell nuclear antigen clamp-associated factor (PCLAF)

Kinesin-like protein KIF20A (KIF20A)

Cytokeratin-5 (KRT5)

Cytokeratin-7 (KRT7)

$\beta$-catenin (CTNNB1)

Integrin $\beta 1$ (ITGB1)

Integrin $\alpha \mathrm{V}($ ITGAV)

Integrin $\alpha 5$ (ITGA5)

Lamin B1 (LMNB1)

Fibronectin 1 (FN1)
F-box protein that mediates the stability of proteins that regulate cell cycle and genome stability Microtubule-associated protein essential for cytokinesis (related to mitosis-related genes in ovarian cancer)

Metalloproteinase that mediates extracellular matrix degradation

Transcription factor that modulates the

TGF- $\beta 1 / S M A D 4$ signaling pathway in ovarian cancer

PCNA-binding protein that regulates DNA repair, cell cycle progression, and proliferation (and activates the PI3K/AKT/mTOR signaling pathways in ovarian cancer)

Kinesin protein that participates in cytokinesis and intracellular transportation

Filament protein that is found in FTE stem cells and serous ovarian cancer (may promote stemness)

Filament protein that promotes cell-matrix

adhesion and extracellular matrix degradation in ovarian cancer

Transcriptional co-regulator protein and adaptor protein for cell adhesion that contributes to ovarian

cancer metastasis, stemness, chemoresistance, angiogenesis, and immune evasion

Integrin protein that facilitates the adhesion of ovarian cancer spheroids

$[226,228]$

$[229,230]$

[231]

Integrin protein that facilitates the adhesion of ovarian cancer spheroids

Integrin protein that facilitates the adhesion of ovarian cancer spheroids

Nuclear lamina protein that facilitates the adhesion of ovarian cancer spheroids

Extracellular matrix glycoprotein that facilitates the adhesion of ovarian cancer spheroids
[231] 
Table 2. Cont.

\begin{tabular}{|c|c|c|}
\hline FOXM1 Target (Gene) & Known Oncogenic Mechanism & References \\
\hline \multicolumn{3}{|c|}{ Chemotherapy Resistance and DNA Repair } \\
\hline Exonuclease 1 (EXO1) & Homologous DNA damage repair protein & [232] \\
\hline $\begin{array}{l}\text { Proliferation cell nuclear antigen clamp-associated } \\
\text { factor (PCLAF) }\end{array}$ & $\begin{array}{l}\text { PCNA-binding protein that regulates DNA repair, } \\
\text { cell cycle progression, and proliferation (and } \\
\text { activates the PI3K/AKT/mTOR signaling } \\
\text { pathways in ovarian cancer) }\end{array}$ & [225] \\
\hline Protein regulator of cytokinesis 1 (PRC1) & $\begin{array}{c}\text { Microtubule-associated protein essential for } \\
\text { cytokinesis (related to mitosis-related genes in } \\
\text { ovarian cancer) }\end{array}$ & [223] \\
\hline Cyclin B1 (CCNB1) & Cyclin protein that promotes mitosis & [233] \\
\hline BRCA1 (BRCA1) & Homologous DNA damage repair protein & {$[233,234]$} \\
\hline BRCA2 (BRCA2) & Homologous DNA damage repair protein & [234] \\
\hline RAD51 (RAD51) & Homologous DNA damage repair protein & {$[233,234]$} \\
\hline Fanconi anemia group $\mathrm{F}$ protein $(F A N C F)$ & Homologous DNA damage repair protein & [233] \\
\hline RAD51 paralog D (RAD51D) & Homologous DNA damage repair protein & [233] \\
\hline Fanconi anemia group D2 protein (FANCD2) & Homologous DNA damage repair protein & [233] \\
\hline \multicolumn{3}{|c|}{ Altered Cellular Metabolism } \\
\hline Glucose transporter 1 (GLUT1) & $\begin{array}{l}\text { Glucose transport protein that promotes aerobic } \\
\text { glycolysis in ovarian cancer }\end{array}$ & [235] \\
\hline Hexokinase 2 (HK2) & $\begin{array}{l}\text { Glycolytic enzyme that promotes aerobic } \\
\text { glycolysis in ovarian cancer }\end{array}$ & [235] \\
\hline
\end{tabular}

\subsection{FOXM1 Expression Is Associated with Tumor Progression and Poor Prognosis in Ovarian Cancer}

FOXM1 expression is elevated in multiple stages of ovarian cancer, from initial neoplastic transformation to late-stage metastatic spread. In one study, immortalized FT stem cells were observed to have higher FOXM1 expression than non-immortalized counterparts and STICs isolated from women with HGSC revealed higher expression of FOXM1 than normal FTE [236]. In addition, FOXM1 is expressed in STIC lesions in concert with FOXO3A downregulation [151]. These data suggest the FOXM1 upregulation in HGSC may occur early and prior to full neoplastic transformation. However, FOXM1 expression clearly shows additional elevation in later disease stages. For example, FOXM1 gene expression in primary EOC, including HGSC, is highly overexpressed compared to normal epithelial ovarian tissues $[30,127,134,161,222]$ and directly correlates with the tumor stages [127] and grade [127,161]. FOXM1 protein expression in EOC positively correlates with lymph node metastasis [237] and FIGO stage [222,238]. We reported that HGSC TCGA cases with FOXM1 gene amplification have overall reduced survival [127] and other studies have demonstrated that FOXM1 protein expression directly correlates with reduced disease-free [239], progression-free [237,240], and overall [237,239] survival in EOC.

\subsection{FOXM1 Promotes Cellular Proliferation, Migration, and Invasion}

Increased FOXM1 expression in cancer promotes cell cycle progression and cell proliferation. In particular, FOXM1 regulation of cell cycle and mitotic genes, such as CCNB1, $C D K 1$, and CENFP, is conserved across different cancer types [44]. We observed that FOXM1 knockdown in immortalized human OSE cells results in the accumulation of cells in G2/M, while FOXM1 knockdown in HGSC cells led to accumulation of cells in G1 [127]. In both cell models, FOXM1 knockdown downregulated the expression of SKP2, PLK1, and CCNB1 and this is consistent with inhibition of cell cycle transitions [127].

Additional studies have demonstrated that FOXM1 promotes ovarian cancer cell migration and invasion. Stabilization of FOXM1 via deubiquitination by OTUB1 promotes cell proliferation and invasion of SKOV3 cells in vitro and increased tumor growth of SKOV3 mouse xenografts in vivo [214]. A separate study demonstrated that FOXM1 knockdown in SKOV3 cells inhibited cell migration and invasion [239]. Conversely, FOXM1 overexpression in A2780/CP70 and OVCA433 cells increased proliferation, migration, and 
invasion. Mechanistically, in OVCA433 cells, FOXM1 overexpression increased mRNA expression of the extracellular proteases MMP9 and PLAUR [206], while the FOXM1 inhibitor thiostrepton decreased cell migration and invasion in conjunction with reducing MMP9 and PLAUR expression [206]. In another study, FOXM1 knockdown decreased ovarian cancer tumor growth in xenografts [229]. FOXM1 knockdown in the EOC cell lines EOC-CC1 and OSPC2 inhibited cell proliferation, colony formation, and invasion, which coincided with decreased expression cell cycle genes and metastasis genes [222].

FOXM1 gene targets that are relevant to cell proliferation, migration, and invasion have been described. Notably, many are overexpressed in ovarian cancer and are reported to correlate with poor prognosis. These include: SKP2 [127], PLK1 [127], CCNB1 [127,222], CDC25B [222], CEP55 [222], CENPF [222], TOP2A [222], CCNF [223], PRC1 [223], and $M M P 2$ [222]. In addition, several novel FOXM1 gene targets have been identified in ovarian cancer. For example, the cytoskeleton proteins cytokeratin-5 (KRT5) and cytokeratin-7 (KRT7) are known to promote migration in SKOV3 cells [226]. DLX1 [224], PCLAF [225], KIF20A [223], and CTNNB1 [229] have been shown to contribute to proliferation and metastatic phenotypes. Moreover, FOXM1 target genes can be linked to broader cancer pathways. KRT5 is found in a population of basally located CD44 ${ }^{+}$stem-like cells in the FTE, for which its population is expanded in serous cancer samples [227]. KRT7 upregulates integrin $\beta 1$-FAK signaling and matrix metalloproteinase expression, promoting cell matrix adhesion [241] and extracellular matrix degradation [228], respectively. The homeobox protein DLX- 1 is a mediator in TGF- $\beta 1 /$ SMAD4 signaling in ovarian cancer [224], which promotes EMT and cell stemness phenotypes [242]. The proliferation cell nuclear antigen (PCNA) clamp-associated factor PCLAF activates the PI3K/AKT/mTOR pathway in ovarian cancer cells [225]. CTNBB1 encodes $\beta$-catenin, which contributes to ovarian cancer metastasis, stemness, chemoresistance, angiogenesis, and immune evasion [230]. Interestingly, FOXM1 can bind directly to $\beta$-catenin to promote its nuclear localization and transcriptional activity in glioma; this provides an addition link between FOXM1 and $\beta$-catenin [243].

In ovarian cancer, FOXM1 also induces the expression of integrins and matrix proteins: ITGB1 [231], ITGAV [231], ITGA5 [231], LMNB1 [231], and FN1 [231], which may facilitate adhesion of ovarian cancer cells to new organs. In keratinocytes, ectopic overexpression of FOXM1 in combination with the loss of TP53 enhanced integrin $\beta 1$ expression [145]. Consistently, the lung vasculature in FOXM1 ${ }^{-/-}$mouse embryos demonstrated a downregulation of integrin $\beta 1$ and laminins $\alpha 2$ and $\alpha 4$, and FOXM1 was demonstrated to transactivate the LAMA4 promoter [21]. There is also evidence that FOXM1 targets Ecadherin, although this has not been reported in ovarian cancer [244]. E-cadherin plays a dynamic role in ovarian cancer, where its overexpression is important for the growth and survival of ovarian cancer cells $[245,246]$, its fragmentation is important for intraperitoneal metastasis [246,247], and its re-expression is a key part of mesenchymal-to-epithelial transition (MET) [245,248]. Taken together, these studies suggest that FOXM1 regulates the expression of key adhesion molecules and promotes their expression in contexts favorable to ovarian cancer progression.

In addition to cancer cells, the tumor microenvironment (TME) plays a critical role in ovarian cancer [249]. While not yet explored in ovarian cancer, investigations in other cancers have shed light on the role of FOXM1 in TME development and maintenance. A mouse model with a macrophage-specific Foxm1 deletion (macFoxm $1^{-/-}$) demonstrated decreased macrophage recruitment and migration to lung tumors and ultimately reduced the number and size of lung tumors formed [250]. In cancer-associated fibroblasts (CAFs), FOXM1 and its downstream targets are upregulated in several cancers [251] and hepatocellular carcinoma CAFs rely on FOXM1 to activate cartilage oligomeric matrix protein $(C O M P)$ gene expression, which eventually increases EMT, invasion, and stemness of hepatocellular carcinoma cells [252]. The recent development of mouse models that recapitulate TME observed in human ovarian cancer $[253,254]$ provides a ripe opportunity to study the role of FOXM1 in the ovarian cancer TME. 


\subsection{FOXM1 Promotes DNA Repair and Chemotherapy Resistance}

Most ovarian cancers are diagnosed at advanced stages and ultimately develop chemoresistance. FOXM1, whose transcriptional network includes DNA repair genes [255], has been reported to promote ovarian cancer resistance to taxanes (e.g., paclitaxel and docetaxel), platinum-based drugs (e.g., cisplatin and carboplatin), and PARPi (e.g., olaparib and niraparib). For example, cisplatin-resistant or paclitaxel-resistant IGROV1 cells showed significant increases in FOXM1 expression, and FOXM1 contributed to the chemoresistant phenotype [240]. Additionally, FOXM1 knockdown in EOC cell lines EOC-CC1 and OSPC2 decreased the expression of DNA damage response genes (ASPM, XRCC1, XRCC4, and RAD51) and chemoresistance genes (CXCR4, CYR61, and EDN1) and concomitantly increased cell sensitivity to several chemotherapy agents, including carboplatin, cisplatin, doxorubicin, and olaparib [222].

In HGSC patients, shallow whole genome sequencing (sWGS) of circulating tumor DNA (ctDNA) from plasma revealed a 16\% increase in chromosome 12p13.33 amplification (location of FOXM1) after the acquisition of chemotherapy resistance [128]. In agreement, we observed that almost half of HGSC patients have increased FOXM1 expression in recurrent chemoresistant tumors [256]. Bioinformatic analysis led to the identification of FOXM1 as one of the top three hub genes for which overexpression leads to platinum-based chemotherapy resistance [257]. Furthermore, cisplatin-resistant ovarian cancer tissues and cells were reported to have increased FOXM1 [232] and FOXM1 was an independent indicator of shorter time to progression in platinum-resistant EOC [222]. A2780 and SKOV3 cells treated with cisplatin demonstrated increased FOXM1 protein expression in a dose-dependent manner [232]. Additionally, ectopic overexpression in BG-1 and A2780 cells enhanced cisplatin resistance, while FOXM1 knockdown sensitized SKOV3 and A2780/CP70 cells to cisplatin [232,240]. Taken together, these data implicate FOXM1 in promoting chemoresistance, particularly to platinum-based drugs, in ovarian cancer.

Several studies have reported that the FOXM1 small molecule inhibitor (SMI) thiostrepton sensitizes ovarian cancer cells to platinum-based chemotherapy $[258,259]$. For example, thiostrepton in combination with cisplatin increased cell death in ovarian cancer cell lines and human ovarian cancer ascites cells ex vivo than compared to treatment with platinum alone [260]. In EOC cell lines A2780 and HEC-1A, treatment with thiostrepton $(1-10 \mu \mathrm{M})$ in combination with cisplatin had a synergistic effect on cell death [136]. Pretreatment of the cisplatin-resistant ovarian cancer cell line A2780/CP70 with thiostrepton increased cisplatin sensitivity in vitro and in xenografts [240]. However, the mechanistic link between these phenotypes and FOXM1 is uncertain since thiostrepton has pleiotropic effects [261-263].

Investigations of FOXM1 also support that there is a role with respect to PARPi and taxane resistance in ovarian cancer $[222,233,240]$. For example, treatment of ovarian cancer patient tissues ex vivo with the PARPi olaparib increased BRCA1, BRCA2, RAD51, and FOXM1 gene expression, and treatment of the tissues with olaparib and thiostrepton reversed this effect. Moreover, the combination treatment, but not olaparib alone, led to decreased proliferation and increased apoptosis [234]. Furthermore, FOXM1 inhibition by siRNA or thiostrepton sensitized EOC cells to olaparib, which correlated with apoptosis, increased DNA damage, and increased PARP1 trapping [233]. Thiostrepton treatment sensitized rucaparib-resistant EOC cell lines to the PARPi rucaparib [233]. FOXM1 has also been shown to promote taxane resistance in breast cancer [216,264,265], gastric cancer [266-268], hepatocellular carcinoma [269], prostate cancer [270], and nasopharyngeal carcinoma [271].

FOXM1 transcriptional targets linked to platinum resistance in ovarian cancer include exonuclease 1 (EXO1) [232], a DNA repair protein recruited to double-stranded breaks, and PCLAF [225], a protein that activates the PI3K/AKT/mTOR signaling pathway. In addition, Protein regulator of cytokinesis-1 (PRC1), which promotes proliferation, migration, and invasion, is a direct FOXM1 transcriptional target found to promote resistance to multiple agents (cisplatin, taxol, and doxorubicin) [223]. Finally, olaparib treatment of EOC cells stimulated FOXM1 binding to the promoters of CCNB1 [233], BRCA1 [233,234], BRCA2. [234], RAD51 [233,234], FANCF [233], RAD51D [233], and FANCD2 [233], which, 
given the function of these genes, are likely to promote PARPi resistance. FOXM1 is also associated with the upregulation of inhibitor of apoptosis (IAP) genes, including survivin (BIRC5) and X chromosome-linked IAP (XIAP) in several cancers [272-275]. Further research on the link between FOXM1 and IAPs, which are intimately related to anti-cancer therapy resistance [276], may reveal additional FOXM1 transcriptional targets linked to ovarian cancer chemoresistance.

\subsection{FOXM1 Promotes Cancer Cell Stemness}

Cancer stem cells (CSC) have enhanced capacities for self-renewal, cell plasticity, and the ability to adapt to harsh environments [277-279]. These characteristics facilitate therapy resistance, disease recurrence, and reduced patient survival [277-279]. As ovarian cancer has high recurrence rates, targeting stemness is of particular interest $[278,279]$. The FOXM1 transcriptional network includes pluripotency genes, such as SOX2, NANOG, and OCT4, in several cancer models [280-283]. Interestingly, FOXM1 depletion in human embryonic stem cells led to a disruption in proliferation but did not impact OCT4 and NANOG expression during in vitro differentiation [235], suggesting that the ability of FOXM1 to modulate pluripotency may be restricted to specific settings which cancer cells are able to exploit.

In ovarian cancer, FOXM1 has been reported to promote cancer cell stemness. CSCs generated from EOC cell lines SKOV3 and A2780 demonstrated elevated levels of FOXM1 in addition to the CSC markers CD133, CD44, and ALDH1 [284]. The synthetic genistein analogue 7-difluormethoxyl-5,4'-di-n-octylgenistein (DFOG) downregulated FOXM1 expression concurrent with CD133, CD44, and ALDH1 and dramatically attenuated sphereforming abilities [284]. In agreement, ectopic expression of FOXM1 reversed these effects [284]. ALDH1-high cells isolated from A2780 and the cisplatin-resistant sub-line A2780/CP70 expressed increased levels of FOXM1, NOTCH1, OCT4, and NANOG and demonstrated enhanced sphere-forming abilities [285]. Treatment of these cells with the ALDH1 inhibitor diethylaminobenzaldehyde (DEAB) downregulated sphere-forming abilities and FOXM1 expression, while thiostrepton treatment did not affect ALDH1 expression, suggesting that FOXM1 is downstream of ADLH1-induced stemness [285]. Chemoresistance can also be a sign of stemness. Indeed, the cisplatin-resistant A2780/CP70 cell line demonstrated enhanced sphere formation ability and increased protein levels of FOXM1, ALDH1, OCT4, NANOG, and NOTCH1 compared to the A2780 parental line [240]. FOXM1 overexpression in A2780 and BG-1 cells increased sphere formation, while knockdown of FOXM1 in A2780/CP70 and SKOV3 cells decreased sphere formation [240]. In addition to ovarian cancer, FOXM1 is linked to CSC phenotypes in other cancers, including lung [286-288], liver [289,290], glioma [291-293], breast [294], colon [295], prostate [270], endometrial [296], and embryonal carcinoma [297].

\subsection{FOXM1 Promotes Genomic Instability and DNA Replication Stress}

A defining feature of HGSC is genomic instability, manifested in large part by increased SCNAs $[30,116,298]$. A seminal early study showed that FOXM1 and several of its transcriptional targets, such as AURKB and CCNB1, rank in the top 70 genes for which overexpression is associated with chromosomal instability (CIN) in pan-cancer (named the CIN70 signature) [299]. More recently, we and others have reported that FOXM1 and its transcriptional program are enriched in tumors with elevated CIN/functional aneuploidy $[27,299,300]$. Interestingly, we have also observed significant association between FOXM1, genomic instability, and DNA hypomethylation in EOC [301]. There is a well-established link between DNA hypomethylation and genomic instability in cancer [302,303]. Intriguingly, ectopic FOXM1 expression in oral keratinocytes was shown to concurrently induce genomic instability and DNA hypomethylation [304]. The pattern of DNA hypomethylation in these cells resembled that seen in the head and neck squamous cell carcinoma cell line SCC15 [305]. It is unknown whether FOXM1 can similarly induce genomic instability and DNA hypomethylation in ovarian cancer cell models. 
In epidermal keratinocytes, ectopic FOXM1 expression and UVB exposure induced SCNAs and loss of heterozygosity (LOH), predisposing cells to a "second hit" on the DNAdamage checkpoint responses (e.g, TP53 mutations) that promote malignant transformation [306]. Moreover, FOXM1 promoted the proliferation and attenuated the differentiation of keratinocytes [145]. These observations suggest that FOXM1 may drive accelerated G2/M progression, thus preventing cells with irreparable DNA damage from committing to terminal differentiation [145].

DNA replication stress (RS) is caused by extrinsic and intrinsic factors that disrupt replication fork dynamics, and critically, RS is a major driver of cancer genomic instability $[307,308]$. Notably, FOXM1 was recently reported to induce DNA replication stress in vitro and FOXM1 expression was observed to correlate with expression of RS biomarkers in several cancer types, including HGSC [309]. Our recent study also suggests a link between FOXM1 and RS. We showed that RHNO1, which encodes a DNA damage repair protein involved in the cellular RS response, shares a head-to-head (i.e., bidirectional) gene arrangement with FOXM1 on chromosome 12p13.33 [256]. Activation of the FOXM1/RHNO1 bidirectional promoter (F/R-BDP) leads to balanced gene expression of both genes and we observed that FOXM1 and RHNO1 each promote HGSC cell growth, survival, and homologous recombination (HR) DNA damage repair [256]. Importantly, FOXM1 and RHNO1 promoted olaparib and carboplatin resistance, and CRISPR-dCas9mediated repression of the F/R-BDP reversed these effects [256]. We postulate that cancer cells have a selective advantage for FOXM1 and RHNO1 co-expression since FOXM1 drives RS and downstream oncogenic phenotypes such as genomic instability, while RHNO1 helps mitigate FOXM1-induced RS to a level more favorable to cancer cell survival.

\subsection{FOXM1 Is Linked to Altered Cellular Metabolism}

FOXM1 is known to contribute to metabolic cellular processes. For example, a proteomics study of the breast cancer cell line MCF-7 revealed that FOXM1 altered the expression of 37 proteins associated with mitochondrial biogenesis and glycolysis [294]. In pancreatic cancer, FOXM1 expression was upregulated in a glucose-dependent manner, which correlated with epithelial-to-mesenchymal transition (EMT) in pancreatic cancer cell lines [310]. In addition, downregulation of FOXM1 induced pancreatic cancer cells to use mitochondrial respiration rather than aerobic glycolysis in high-glucose medium, further linking FOXM1 to the glycolytic pathway [310]. Similarly, FOXM1 knockdown decreased glucose utilization, lactate production, and lactate dehydrogenase (LDH) activity in several pancreatic cell lines and downregulated phosphoglycerate kinase 1 (PGK-1) and lactate dehydrogenase A (LDHA) [311]. Further investigation revealed that FOXM1 binds directly to the $L D H A$ promoter to promote its expression in pancreatic cancer cells [311]. FOXM1 was also found to transactivate $L D H A$ in gastric cancer, promoting a glycolytic phenotype with high proliferative, migratory, and invasive abilities [312]. Similarly, FOXM1 knockdown decreased glucose uptake and lactate production in the hepatocellular carcinoma cell line Hep3B, and the overexpression of FOXM1 in the hepatocellular carcinoma cell line MHCC-97H increased glucose uptake and lactate production, but only when appropriate levels of glucose transporter 1 (GLUT1) were present [313]. As part of this regulatory mechanism, FOXM1 directly transactivated the GLUT1 promoter [313]. FOXM1 has also been shown to regulate the level of the oncometabolite D-2-hydroxyglutarate, by activating the isocitrate dehydrogenase 1 (IDH1) promoter in the fibrosarcoma cell line HT-1080 [314].

Two observations support that FOXM1 may also be important for metabolic reprogramming in ovarian cancer. First, FOXM1 gene expression is upregulated in ovarian cancer cells by both the metabolic enzyme aspartate $\mathrm{N}$-acetyltransferase, which is overexpressed and associated with worse clinical outcomes in HGSC, and N-acetylaspartate, which is the most abundant onco-metabolite in HGSC tissues [315]. Second, FOXM1 directly binds to the promoters of GLUT1 and hexokinase 2 (HK2) in EOC cell lines A2780 and SKOV3, and FOXM1 knockdown resulted in decreased aerobic glycolysis in these cell lines [316]. Moreover, both mRNA and protein expression of GLUT1 and HK2 positively 
correlated with FOXM1 in EOC tissues [235]. Taken together, these data suggest that altered amino acid metabolism in ovarian cancer cells upregulates FOXM1, which alters glycolysis and mitochondrial respiration by promoting aerobic glycolysis. The Warburg effect, wherein tumor cells metabolize glucose through aerobic glycolysis as opposed to oxidative phosphorylation, is well-known for promoting proliferation, metastasis, stemness, and therapy resistance [317,318]. Furthermore, as glycolysis and mitochondrial activity affect fatty acid metabolism [319], FOXM1 may also play a role in fatty acid metabolism. Further study on the relationship between FOXM1 and ovarian cancer metabolism is highly encouraged.

\subsection{FOXM1 Isoform Expression and Function in Cancer}

As mentioned earlier, FOXM1 is distinguished by three principal isoforms $(a, b$, and c) (Figure 1). While several early cancer investigations focused on FOXM1b [32, 320], our recent studies of the TCGA database and human HGSC tissues revealed that FOXM1c is the highest expressed FOXM1 isoform in both pan-cancer and HGSC [27,127]. Consistent with our findings, it was demonstrated that FOXM1c had the highest expression compared to FOXM1b and FOXM1a in a panel of EOC cell lines [321]. FOXM1c has also been associated with proteolytic processing that removes the NRD, which may result in constitutive activation [322]. In a bioinformatic study analyzing FOXM1 isoforms enriched in 12 ovarian cancer tissues compared to 18 normal control tissues, two novel FOXM1 isoforms missing the NRD were identified within the top 5\% enriched isoform genes [36]. However, the sequences of these isoforms suggested that they are not translated into proteins and their functional contribution to ovarian cancer remains unknown (Table 1).

It is likely that FOXM1b and FOXM1c have common transcriptional targets, given the similarities of the proteins as well as data showing that both isoforms can target oncogenic DLX1 in ovarian cancer cells [224]. In addition, our recent isoform-specific overexpression and RNA-sequencing (RNA-seq) study revealed a number of common transcriptional targets between FOXM1b and FOXM1c, as well as some distinct targets [27]. Predictably, gene expression changes were largely absent from FOXM1a overexpressing cells [27] and this is consistent with its reported transcriptional incompetence [12].

Some studies suggest that FOXM1b and FOXM1c expression may have distinct phenotypic consequences. Previous work in several cancer cell lines, including the ovarian cancer cell line A2780/CP70, observed that FOXM1b had a higher transforming ability than FOXM1c and this is as measured by anchorage-independent growth [322]. However, another study reported that FOXM1c promoted proliferation, migration, and invasion, while FOXM1b only promoted cell migration and invasion in EOC cells [206]. In a study of the newly EOC-derived cell lines EOC-CC1 and OSPC2, higher amounts of FOXM1c than FOXM1b expression were detected (which matched their original clinical biopsy specimens) [222]. In this study, the highest amount of FOXM1c compared to FOXM1b expression was found in OSPC2 cells from patient ascites [222]; this suggests that FOXM1c may be upregulated when cells have adopted a mesenchymal (metastatic) phenotype. Therefore, while FOXM1b and FOXM1c are both able to promote oncogenic phenotypes, FOXM1c may promote more proliferative and metastatic phenotypes and, due to its higher relative expression [27,127], FOXM1c may be the most relevant isoform to overexpress and model in ovarian cancer investigations.

Some work has specifically linked FOXM1c to the MAPK/ERK pathway. Only FOXM1c, which contains two functional ERK1/2 target sequences [56], was found to be sensitive to activation by MAPK/ERK in HEK293 cells [322]. Similarly, in the mouse fibroblast line NIH/3T3, constitutively active MEK1 promoted FOXM1c, but not FOXM1b, transactivation of the CCNB1 promoter [56]. As mentioned earlier, the connection between MAPK/ERK and FOXM1 in ovarian cancer has only been demonstrated in EOC cell lines with wild-type p53, and it has been suggested that the MAPK/ERK pathway may not interact with FOXM1 in mutant p53 settings [206]. Therefore, it is not entirely clear if the interaction between MAPK/ERK and FOXM1c is relevant in ovarian cancer. 


\section{Clinical Translation}

\subsection{FOXM1 Has Potential as a Prognostic Biomarker in Ovarian Cancer}

Numerous studies have linked FOXM1 expression to poor prognosis in ovarian cancer. FOXM1 mRNA expression associates with higher EOC tumor grades $[127,161]$ and stages [127], and FOXM1 protein expression associates with EOC lymph node metastasis [237] and a higher FIGO stage [222]. HGSC tumors with FOXM1 gene amplification have increased FOXM1 mRNA expression and reduced overall survival [127]. EOC tumors with high FOXM1 mRNA expression showed reduced progression-free and overall survival [238]. EOC tumors with elevated FOXM1 protein expression were associated with reduced disease-free [239], progression-free [237,240], and overall [237,239] survival. Meta-analyses of FOXM1 in human solid tumors reported that FOXM1 protein expression in ovarian tumors coincides with an overall hazard ratio (HR) of $1.34(95 \% \mathrm{CI}=0.96-1.88)$ for overall survival [323] and an odds ratio (OR) of 2.34 (95\% CI $=1.30-4.20)$ for 3-year overall survival [324]. In addition, during the early stage, non-serous EOC FOXM1 protein levels correlated with poor prognosis in mucinous OC and improved the predictive power of current clinical markers (age, stage, CA-125, and ploidy) [325]. Most remarkably, a pancancer meta-analysis of the transcriptomes of $\sim 18,000$ human tumors identified FOXM1 expression as the top single gene predictor of poor prognosis in cancer [221]. FOXM1 was also shown to outperform the widespread clinical marker, MKI67 (encodes Ki-67), for predicting survival [221]. These data suggest FOXM1 should be aggressively pursued as a prognostic ovarian cancer biomarker in clinical validation studies.

\subsection{In Vivo Studies of FOXM1 in Ovarian Cancer Are Limited}

Although in vitro ovarian cancer models provide invaluable insight into the function of FOXM1 in ovarian cancer, cell lines do not adequately recapitulate in vivo disease. For example, cell lines may experience selective pressure, genetic drift, and genomic instability, resulting in phenotypic changes (including drug response) that no longer reflect the original tumor [326,327]. Furthermore, cell lines do not interact with the tumor microenvironment (TME) or engage in metastatic processes in the manner experienced by tumors in vivo. In vivo ovarian cancer models include cell line xenografts, patient-derived xenografts (PDX), syngeneic transplant (i.e., allograft) models, and genetically engineered mouse models (GEMM) [328].

Several considerations drive the need for the continued development of in vivo ovarian cancer models. First, the anti-VEGF monoclonal antibody bevacizumab improves progression-free survival in women with ovarian cancer $[329,330]$, demonstrating the importance of angiogenesis in ovarian cancer. Second, the matrisome [331], including collagen-remodeling genes [332] and cancer-associated fibroblasts (CAF) [333], participates in ovarian cancer progression. Third, while ovarian cancers exist in a generally immunosuppressive environment [334], ovarian tumors contain tumor-associated lymphocytes $[221,335,336]$ and a subset of patients with ovarian cancer respond to immunotherapy $[334,337]$. Fourth, a key route of ovarian cancer metastasis is via the peritoneal fluid, which carries exfoliated tumor cells to locations including the omentum, peritoneal lining, colon, diaphragm, and small bowel [338]. These metastatic sites can provide different environmental niches for EOC cells. For instance, when metastasizing to the omentum, cancer cells preferentially attach to areas of immune cell aggregates that contain high vascular density [339]. Greater than 70\% of ovarian cancer patients have diffuse peritoneal carcinomatosis at initial presentation [338], rendering it a critical process to model in scientific investigations.

The scope of the literature examining the function of FOXM1 using in vivo ovarian cancer models is currently limited. FOXM1 is overexpressed in an ovarian cancer GEMM driven by dual p53/Rb knockout in the OSE [127,340]. Recently, novel allograft models $[253,254]$ and GEMMs [94] were shown to recapitulate critical aspects of human HGSC, including TME and metastasis. Notably, in the GEMM study, Dicer1-Pten double knockout (DKO) mice (Dicer $1^{\text {flox } / \text { flox } P t e n}{ }^{\text {flox/flox }}$ Amhr $2^{\text {cre/+}}$ ) and Dicer1-Pten-Trp53 triple knockout 


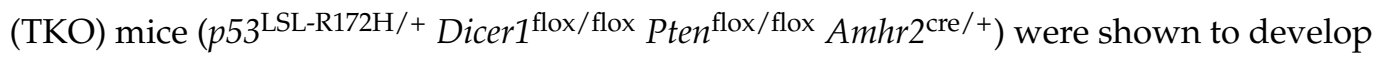
tumors exhibiting an activated FOXM1 network, which correlated with genomic instability [94]. In addition to Tp53, alterations in DICER1 and PTEN are common alterations in human HGSC and PTEN deletion is linked to FOXO3A downregulation $[94,341]$. The data from these GEMM models are in agreement with our pan-cancer analysis, which linked FOXM1 mRNA and protein expression to genomic instability [27]. Thus, novel GEMMs may provide highly relevant in vivo models to interrogate FOXM1 function in ovarian cancer development and progression.

\subsection{Therapeutic Targeting of FOXM1 in Ovarian Cancer}

There is strong rationale for targeting FOXM1 in cancer, particularly in aggressive cancers with poor survival outcomes such as ovarian cancer. In general, two therapeutic strategies can be used to impair FOXM1: (1) inhibiting upstream pathways that induce and/or activate FOXM1and (2) inhibiting FOXM1 directly. For the former, several inhibitors of pathways upstream of FOXM1 are used in the clinic or are in clinical trials. In contrast, FOXM1 inhibitors (FOXM1i) have not yet entered clinical trials. However, several direct inhibitors have been used in pre-clinical studies, and there will likely be future clinical testing on these agents. Since ovarian cancers ultimately develop resistance to most chemotherapy, it is worthwhile to develop both indirect and direct FOXM1 inhibitors in parallel.

\subsection{Inhibitors of Upstream Signaling Pathways}

The ErbB family of receptor tyrosine kinases (RTKs) activate the MAPK/ERK [342], PI3K/AKT [342], and PLK1 [146,343] signaling pathways, all of which are upstream kinases that phosphorylate and activate FOXM1. The pan-ErbB receptor inhibitor dacomitinib mitigated FOXM1 activity through reduced levels of phospho-PLK1 in chemotherapy-resistant EOC cells, while single-targeted ErbB inhibitors, such as trastuzumab, had marginal effects on PLK1 and FOXM1 activity [344]. Dacomitinib was also found to reduce FOXM1 activity in pancreatic ductal adenocarcinoma cancer (PDAC) [345], which is another aggressive cancer with poor prognosis and high FOXM1 activity [346]. Selective inhibitors against PI3K, ERK1/2, and AKT decreased FOXM1 gene expression in HGSC cells [154], potentially via their effects on FOXO3A.

PLK1 is a FOXM1 target gene [41] as well as a critical upstream kinase that promotes FOXM1 activation $[57,59]$. Thus, PLK1 inhibitors (PLK1i) may be a highly effective means to target FOXM1 function. Interestingly, the PLK1i BI6727, combined with paclitaxel, was synthetically lethal in CCNE1-amplified HGSC cell lines and triggered mitotic arrest and apoptosis [347]. In combination with dacomitinib, the PLK1i BI2536 synergistically enhanced the sensitivity of chemoresistant EOC cells to cisplatin [344]. It is plausible that the activity of PLK1i observed in these studies involved the disruption of FOXM1. Although BI2536 showed overall limited activity in a phase II trial that included multiple tumor types, the highest proportion of stable disease responses $(76.9 \%)$ was observed in ovarian cancer patients [348]. Another phase I/II trial, using a PLK1-targeted RNAi (TKM-080301), suggested particular efficacy in tumors that overexpress PLK1 and possess an inactivation of wild-type p53 [349], potentially making PLK1i particularly suitable for HGSC. Given their numerous molecular links, it is likely that disruption of FOXM1 signaling accounts for, at least in part, the activity of PLK1i in cancer.

\subsection{Direct FOXM1 Inhibitors}

A variety of molecules that target FOXM1 have now been reported. The tumor suppressor protein $\mathrm{p} 19^{\mathrm{ARF}}$, which is encoded by the INKA4/ARF gene locus, inhibits

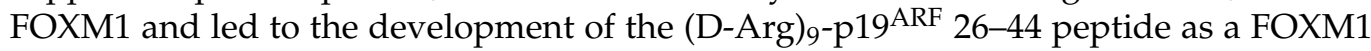
inhibitor $[90,91]$. Interestingly, this inhibitor targets FOXM1 to the nucleolus, resulting in its inactivation [90]. Nevertheless, potential immune responses to the peptide limits its clinical utility [350]. The thiazole antibiotics thiostrepton $[171,259,351]$ and siomycin 
A [352] were the first small molecule inhibitors (SMI) reported to inhibit FOXM1, and thiostrepton is the most widely used FOXM1i to date $[136,205,206,273,275,353]$. One proposed mechanism of action (MOA) of these compounds is that they function as proteosome inhibitors to prevent the degradation of a negative regulator of FOXM1 [354]. Realizing that thiazole antibiotics function as proteosome inhibitors led to the discovery that proteosome inhibitors, such as bortezomib, also inhibit FOXM1 [261,355]. In contrast to this model, another report showed that thiostrepton can bind directly to FOXM1 and suggested that its function as a proteosome inhibitor is a separate effect [351]. More recently, monensin was reported as another antibiotic that inhibits FOXM1 by binding to its DBD [356]. While these agents can have potent anti-cancer effects, their link to FOXM1 is tenuous due to their pleiotropic effects. For instance, thiostrepton inhibits PAX8 in HGSC by a mechanism not dependent on FOXM1 [262] and disrupts mitochondrial protein synthesis [263]. Furthermore, monensin induces mitochondrial ROS production and disrupts $\mathrm{Ca}^{2+}$ homeostasis in human cells [357]. Genistein, an isoflavanoid with broad anti-cancer effects [358], has also been proposed as a FOXM1i [359]. In order to increase the bioavailability of genistein, 7-difluoromethoxyl-5,4'-di-n-octylygenistein (DFOG) was synthesized and this compound was shown to downregulate FOXM1 expression in EOC $[284,360]$ and gastric cancer [361] cells.

Several high-throughput screens (HTS) have been performed in order to identify novel SMI of FOXM1. In the first study, the forkhead domain inhibitor FDI-6 was identified from a screen of $>50,000$ drug-like molecules [362]. FDI- 6 disrupted the binding of FOXM1DBD to RYAAAYA promoter sequences [362]. Although the data presented suggested some specificity to FOXM1, the general mechanism of action of FDI-6 suggests that it might inhibit DNA binding of other FOX family members [362]. Similar to FDI-6, a singlestranded DNA aptamer was designed to target the DBD region of FOXM1, inhibiting FOXM1 transcriptional activity [363]. However, DBD-based inhibitors may not impact the interaction of FOXM1 with other proteins, including oncogenic transcription factor complexes. Thus, inhibitors that result in FOXM1 protein degradation might provide a better therapeutic strategy for targeting FOXM1. In this context, a recent screen of 50,000 small-molecule compounds identified RCM-1 as a FOXM1i [350]. RCM-1 was reported to decrease nuclear FOXM1 protein levels in U2OS C3 cells, and the MOA was reported to involve translocation of nuclear FOXM1 into the cytoplasm, resulting in proteasomal degradation [350]. Another study used computational modeling to screen for FOXM1 SMI in the NCI diversity set of $\sim 2000$ synthetic molecules [321]. This strategy identified $\mathrm{N}$-phenylphenanthren-9-amine as a molecule that may act similarly to thiostrepton in its binding to FOXM1 [321]. In follow-up work, this compound was shown to inhibit FOXM1 in EOC cells [321]. In another recent study, the 1,1-diarylethylene monoamine compound NB-55 emerged from a chemical library screen as a potent SMI of FOXM1 [364]. This agent was shown to inhibit breast cancer cell proliferation more potently than the proliferation of non-malignant mammary epithelial cells [364]. Using NB-55 as a template, the 1,1diarylethylene methiodide salts NB-73 and NB-115 were synthesized and shown to have increased potency, with $\mathrm{IC}_{50}$ values of $\sim 0.6 \mu \mathrm{M}$ for proliferation inhibition and reduction in FOXM1 protein [364]. These compounds appear to bind directly to and destabilize FOXM1, resulting in enhanced proteolysis [364]. A synopsis of the anti-cancer effects of direct FOXM1i in ovarian cancer studies is presented in Table 3. 
Table 3. FOXM1 inhibitors and their effects on ovarian cancer phenotypes.

\begin{tabular}{|c|c|c|c|}
\hline Effect on Ovarian Cancer Cell Phenotype & Concentration & Assays & References \\
\hline \multicolumn{4}{|c|}{ Thiostrepton } \\
\hline Reduced cellular proliferation/viability & $0.1-20 \mu \mathrm{M}$ & XTT, AlamarBlue, sulforhodamine B, MTT & {$[136,205,229,233,260]$} \\
\hline $\begin{array}{l}\text { Reduced cellular proliferation/viability of patient } \\
\text { ascites cells ex vivo when used alone and in } \\
\text { combination with paclitaxel and cisplatin }\end{array}$ & $1-20 \mu \mathrm{M}$ & Sulfohodamine B & [260] \\
\hline $\begin{array}{l}\text { Reduced cellular proliferation/viability synergistically } \\
\text { when used in combination with } 1 \mu \mathrm{M} \text { cisplatin }\end{array}$ & $2.5-10 \mu \mathrm{M}$ & AlamarBlue & [136] \\
\hline $\begin{array}{l}\text { Reduced cellular proliferation/viability by sensitizing } \\
\text { cisplatin-resistant cells to cisplatin }\end{array}$ & $0.5-1 \mu \mathrm{M}$ & MTT & [240] \\
\hline $\begin{array}{l}\text { Reduced cellular proliferation/viability by sensitizing } \\
\text { rucaparib-resistant cells to rucaparib }\end{array}$ & $0.1-1.25 \mu \mathrm{M}$ & Sulfohodamine B & {$[233]$} \\
\hline Reduced cellular migration & $5-20 \mu \mathrm{M}$ & Transwell & {$[154,205,206,229]$} \\
\hline Reduced cellular invasion & $5-20 \mu \mathrm{M}$ & Matrigel transwell & {$[154,205,206,229]$} \\
\hline Reduced colony formation & $5-10 \mu \mathrm{M}$ & Clonogenic & [229] \\
\hline $\begin{array}{c}\text { Reduced colony formation synergistically when used } \\
\text { in combination with } 2.5 \mu \mathrm{M} \text { FH535 ( } \beta \text {-catenin } \\
\text { inhibitor) }\end{array}$ & $5 \mu \mathrm{M}$ & Clonogenic & [229] \\
\hline $\begin{array}{l}\text { Reduced colony formation by sensitizing } \\
\text { PARPi-resistant cells to PARPi }\end{array}$ & $0.5-1 \mu \mathrm{M}$ & Clonogenic & [233] \\
\hline Slowed wound closure rate & $5-10 \mu \mathrm{M}$ & \multirow{2}{*}{$\begin{array}{l}\text { Wound healing } \\
\text { qRT-PCR, western blot, annexin-V/propidium } \\
\text { iodide flow cytometry, caspase-3 activity }\end{array}$} & [206] \\
\hline Induced apoptosis & $1-10 \mu \mathrm{M}$ & & {$[136,229,233,260]$} \\
\hline $\begin{array}{l}\text { Induced apoptosis synergistically when used in } \\
\text { combination with } 2.5 \mu \mathrm{M} \text { FH535 ( } \beta \text {-catenin inhibitor) }\end{array}$ & $5 \mu \mathrm{M}$ & Annexin-V/propidium iodide flow cytometry & [229] \\
\hline Induced DNA damage & $7.5-10 \mu \mathrm{M}$ & Alkaline comet & [233] \\
\hline $\begin{array}{l}\text { Induced PARP1 trapping onto chromatin when } \\
\text { combined with Olaparib }\end{array}$ & $5-10 \mu \mathrm{M}$ & PARP trapping & {$[233]$} \\
\hline Reduced sphere formation & $1 \mu \mathrm{M}$ & Spheroid formation & [295] \\
\hline Decreased HUVEC tube formation and VEFG secretion & $5-10 \mu \mathrm{M}$ & HUVEC tube formation, ELISA & [229] \\
\hline Decreased MMP-9 and PLAUR gene expression levels & $5-10 \mu \mathrm{M}$ & Sem-quantitative RT-PCR & [206] \\
\hline Decreased NOTCH1 protein expression levels & $1 \mu \mathrm{M}$ & Western blot & [295] \\
\hline $\begin{array}{l}\text { Decreased active } \beta \text {-catenin, overall } \beta \text {-catenin, TCF4, } \\
\text { cyclin D1, cMYC, uPAR, VEGF, MMP-9, and MMP-2 } \\
\text { protein expression levels when used alone and in } \\
\text { combination with FH535 ( } \beta \text {-catenin inhibitor) }\end{array}$ & $5 \mu \mathrm{M}$ & Western blot & [229] \\
\hline Reduced tumor size in mice & $\begin{array}{c}200-300 \mu \mathrm{MM} / \mathrm{kg}, 20-50 \\
\mathrm{mg} / \mathrm{kg}\end{array}$ & Cell line-derived xenograft & {$[205,229,231,240]$} \\
\hline $\begin{array}{l}\text { Reduced tumor size in mice when used in combination } \\
\text { with cisplatin }\end{array}$ & $50 \mathrm{mg} / \mathrm{kg}$ & Cell line-derived xenograft & [240] \\
\hline $\begin{array}{c}\text { Reduced tumor size in mice when used in combination } \\
\text { with latanib }\end{array}$ & $20 \mathrm{mg} / \mathrm{kg}$ & Cell line-derived xenograft & {$[231]$} \\
\hline $\begin{array}{l}\text { Reduced tumor size in mice when used in combination } \\
\text { with FH535 ( } \beta \text {-catenin inhibitor) }\end{array}$ & $20 \mathrm{mg} / \mathrm{kg}$ & Cell line-derived xenograft & {$[229]$} \\
\hline $\begin{array}{c}\text { Increased overall survival in mice when used in } \\
\text { combination with latanib }\end{array}$ & $20 \mathrm{mg} / \mathrm{kg}$ & Cell line-derived xenograft & {$[231]$} \\
\hline $\begin{array}{l}\text { Reduced number of tumor spheroids in the peritoneal } \\
\text { fluid in mice when used alone and used in } \\
\text { combination with latanib }\end{array}$ & $20 \mathrm{mg} / \mathrm{kg}$ & Cell line-derived xenograft & [231] \\
\hline $\begin{array}{l}\text { Reduced cellular proliferation and induced apoptosis } \\
\text { in patient tumors grown ex vivo alone, in combination } \\
\text { with olaparib, and in combination with carboplatin }\end{array}$ & $3 \mu \mathrm{M}$ & Immunofluorescence on fixated tissue & [234] \\
\hline \multicolumn{4}{|c|}{ FDI-6 } \\
\hline Reduced cellular proliferation/viability & $1-30 \mu \mathrm{M}$ & $\begin{array}{l}\text { Not specified, cell counting kit- } 8 \text { and } \\
\text { microscopic imaging analysis }\end{array}$ & {$[362,365]$} \\
\hline $\begin{array}{l}\text { Reduced cellular proliferation/viability when used in } \\
\text { combination with tipifarnib, sapatinib, or rottlerin }\end{array}$ & $3-10 \mu \mathrm{M}$ & $\begin{array}{c}\text { Cell counting kit- } 8 \text { and microscopic imaging } \\
\text { analysis }\end{array}$ & [365] \\
\hline Increased N-Ras protein expression & $1-10 \mu \mathrm{M}$ & Western blot & [365] \\
\hline Decreased p-PKC $\delta$ and HER3 protein expression & $1-10 \mu \mathrm{M}$ & Western blot & [365] \\
\hline \multicolumn{4}{|c|}{ 7-difluoromethoxyl-5,4-di-n-octyl genistein (DFOG) } \\
\hline Reduced cellular proliferation/viability & $1-10 \mu \mathrm{M}$ & MTT & {$[360]$} \\
\hline Reduced colony formation & $1-10 \mu \mathrm{M}$ & Clonogenic & {$[360,366]$} \\
\hline Induced G2/M-phase cell cycle arrest & $1-10 \mu \mathrm{M}$ & Cell cycle analysis & [360] \\
\hline Induced apoptosis & $1-10 \mu \mathrm{M}$ & $\begin{array}{l}\text { Histone/DNA ELISA, propidium iodide flow } \\
\text { cytometry }\end{array}$ & {$[360]$} \\
\hline Reduced sphere formation & $1-10 \mu \mathrm{M}$ & Spheroid formation & [366] \\
\hline $\begin{array}{l}\text { Decreased CD133, CD44, ALDH1, and NF-kBp65 } \\
\text { protein expression levels }\end{array}$ & $1-10 \mu \mathrm{M}$ & Western blot & {$[366]$} \\
\hline $\begin{array}{l}\text { Decreased phosphorylation of AKT, ERK1/2, and } \\
\text { FOXO3A }\end{array}$ & $3-10 \mu \mathrm{M}$ & Western blot & [366] \\
\hline \multicolumn{4}{|c|}{$N$-phenylphenanthren-9-amine } \\
\hline Reduced cellular proliferation/viability & $0.01-10 \mu \mathrm{M}$ & Sulforhodamine B & [321] \\
\hline
\end{tabular}




\section{Conclusions and Future Perspectives}

Emerging evidence implicates FOXM1 as a crucial oncoprotein and driver of ovarian cancer. High FOXM1 expression and activity in ovarian cancer are promoted by several mechanisms, including inactivation of upstream tumor suppressors, gene amplification, transcriptional and translational upregulation, increased protein phosphorylation, and enhanced protein stability (Figure 3). In turn, FOXM1 promotes ovarian cancer by impinging on several cancer hallmarks: sustained proliferative signaling, invasion and metastasis, DNA repair and chemotherapy resistance, cancer stemness, DNA replication stress and genomic instability, and altered cell metabolism (Figure 4).

The major gap in our current knowledge of FOXM1 in ovarian cancer is due to the limited number of studies using in vivo or ex vivo models [94,234]. Future work should focus on the verification of the oncogenic potential of FOXM1 using such models, which is required to provide validation for FOXM1 as a therapeutic target in ovarian cancer. Another key opportunity will be to evaluate the impact of FOXM1 status on the efficacy of existing ovarian cancer therapies. Extensive in vitro data support a role for FOXM1 in ovarian cancer chemotherapy resistance, including platinum-based drugs, taxanes, and PARPi, all of which are currently used to treat ovarian cancer. Conversely, FOXM1 expression was recently reported to be a predictor of increased efficacy for Chk1 and WEE1 inhibitors, which are in clinical testing for ovarian cancer [367-369]. It is thus highly relevant to assess FOXM1 as a biomarker for responsiveness to chemotherapeutic agents in current use as well as in clinical trials for ovarian cancer patients.

Transcription factors have traditionally been considered difficult to therapeutically target. However, new strategies have recently been introduced, including disrupting essential protein-protein interactions and promoting targeted proteasomal degradation [370]. Several FOXM1i have been reported, and many appear to bind to and destabilize FOXM1, although their specificity to FOXM1 versus other potential cellular targets requires further characterization. Novel approaches, such as proteolysis targeting chimaeras (PROTACs), could substantially aid in the effort to degrade oncogenic transcription factors such as FOXM1 with increased specificity [370]. Additional FOXM1-targeting methods that may emerge in the future include siRNA, shRNA, and CRISPR-based approaches [371-373], which could potentially be delivered intraperitoneally to gain direct access to ovarian cancer cells. Successful targeting of estrogen receptors (ER) in breast cancer and androgen receptors (AR) in prostate cancer has demonstrated the efficacy of targeting oncogenic transcription factors for cancer therapy.

Moving forward, emphasis should be placed on moving FOXM1i studies out of in vitro settings and into state-of-the-art in vivo ovarian cancer models, with the ultimate goal of initiating phase I clinical trials. In summary, the FOXM1 ovarian cancer field is poised to move into a new era that is focused on determining the in vivo roles of FOXM1 in ovarian cancer biology and conducting the initial clinical assessments of its potential as a therapeutic target in patients.

Author Contributions: Writing—Original Draft Preparation, C.L.; writing—review and editing, C.L., C.J.B. and A.R.K. All authors have read and agreed to the published version of the manuscript.

Funding: A.R.K. was supported by NIH R03CA224339, The Marsha Rivkin Center, The Betty J. and Charles D. McKinsey Ovarian Cancer Research Fund, and The Fred \& Pamela Buffett Cancer Center (NCI P30CA036727). C.J.B. was supported by NIH T32CA009476 and NIH F99CA212470. C.L. was supported by NIH T32CA009476.

Conflicts of Interest: The authors declare no conflict of interest.

\section{References}

1. Weigel, D.; Jürgens, G.; Küttner, F.; Seifert, E.; Jäckle, H. The homeotic gene fork head encodes a nuclear protein and is expressed in the terminal regions of the Drosophila embryo. Cell 1989, 57, 645-658. [CrossRef]

2. Kaestner, K.H.; Lee, K.H.; Schlondorff, J.; Hiemisch, H.; Monaghan, A.P.; Schutz, G. Six members of the mouse forkhead gene family are developmentally regulated. Proc. Natl. Acad. Sci. USA 1993, 90, 7628-7631. [CrossRef] 
3. Clevidence, D.E.; Overdier, D.G.; Tao, W.; Qian, X.; Pani, L.; Lai, E.; Costa, R.H. Identification of nine tissue-specific transcription factors of the hepatocyte nuclear factor 3/forkhead DNA-binding-domain family. Proc. Natl. Acad. Sci. USA 1993, 90, $3948-3952$. [CrossRef]

4. Clark, K.L.; Halay, E.D.; Lai, E.; Burley, S.K. Co-crystal structure of the HNF-3/fork head DNA-recognition motif resembles histone H5. Nat. Cell Biol. 1993, 364, 412-420. [CrossRef] [PubMed]

5. Kaestner, K.H.; Knochel, W.; E Martinez, D. Unified nomenclature for the winged helix/forkhead transcription factors. Genes Dev. 2000, 14, 142-146. [PubMed]

6. Jackson, B.C.; Carpenter, C.; Nebert, D.W.; Vasiliou, V. Update of human and mouse forkhead box (FOX) gene families. Hum. Genom. 2010, 4, 345-352. [CrossRef] [PubMed]

7. Myatt, S.S.; Lam, E.W.-F. The emerging roles of forkhead box (Fox) proteins in cancer. Nat. Rev. Cancer 2007, 7, 847-859. [CrossRef]

8. Friedman, J.R.; Kaestner, K.H. The Foxa family of transcription factors in development and metabolism. Cell. Mol. Life Sci. CMLS 2006, 63, 2317-2328. [CrossRef]

9. Seo, S.; Fujita, H.; Nakano, A.; Kang, M.; Duarte, A.; Kume, T. The forkhead transcription factors, Foxc1 and Foxc2, are required for arterial specification and lymphatic sprouting during vascular development. Dev. Biol. 2006, 294, 458-470. [CrossRef]

10. Huang, H.; Tindall, D.J.; Zhang, X.; Sejas, D.P.; Qiu, Y.; Williams, D.A.; Pang, Q. Dynamic FoxO transcription factors. J. Cell Sci. 2007, 120, 2479-2487. [CrossRef] [PubMed]

11. Fleskens, V.; van Boxtel, R. Forkhead Box P family members at the crossroad between tolerance and immunity: A balancing act. Int. Rev. Immunol. 2014, 33, 94-109. [CrossRef] [PubMed]

12. Korver, W.; Roose, J.; Clevers, H. The winged-helix transcription factor Trident is expressed in cycling cells. Nucleic Acids Res. 1997, 25, 1715-1719. [CrossRef]

13. Yao, K.M.; Sha, M.; Lu, Z.; Wong, G.G. Molecular analysis of a novel winged helix protein, WIN. Expression pattern, DNA binding property, and alternative splicing within the DNA binding domain. J. Biol. Chem. 1997, 272, 19827-19836. [CrossRef] [PubMed]

14. Ye, H.; Kelly, T.F.; Samadani, U.; Lim, L.; Rubio, S.; Overdier, D.G.; A Roebuck, K.; Costa, R.H. Hepatocyte nuclear factor $3 /$ fork head homolog 11 is expressed in proliferating epithelial and mesenchymal cells of embryonic and adult tissues. Mol. Cell. Biol. 1997, 17, 1626-1641. [CrossRef]

15. Korver, W.; Roose, J.; Heinen, K.; Weghuis, D.O.; de Bruijn, D.; van Kessel, A.G.; Clevers, H. The HumanTRIDENT/HFH11/FKHL16Gene: Structure, Localization, and Promoter Characterization. Genomics 1997, 46, 435-442. [CrossRef] [PubMed]

16. Westendorf, J.M.; Rao, P.N.; Gerace, L. Cloning of cDNAs for M-phase phosphoproteins recognized by the MPM2 monoclonal antibody and determination of the phosphorylated epitope. Proc. Natl. Acad. Sci. USA 1994, 91, 714-718. [CrossRef]

17. Ramirez, M.I.; Rishi, A.K.; Cao, Y.X.; Williams, M.C. TGT3, Thyroid Transcription Factor I, and Sp1 Elements Regulate Transcriptional Activity of the 1.3-Kilobase Pair Promoter ofT1 $\alpha$, a Lung Alveolar Type I Cell Gene. J. Biol. Chem. 1997, $272,26285-26294$. [CrossRef]

18. Korver, W.; Roose, J.; Wilson, A.; Clevers, H. The Winged-Helix Transcription Factor Trident is Expressed in Actively Dividing Lymphocytes. Immunobiology 1997, 198, 157-161. [CrossRef]

19. Ahn, J.-I.; Lee, K.-H.; Shin, D.-M.; Shim, J.-W.; Kim, C.-M.; Kim, H.; Lee, S.-H.; Lee, Y.-S. Temporal expression changes during differentiation of neural stem cells derived from mouse embryonic stem cell. J. Cell. Biochem. 2004, 93, 563-578. [CrossRef]

20. Krupczak-Hollis, K.; Wang, X.; Kalinichenko, V.V.; Gusarova, G.A.; Wang, I.C.; Dennewitz, M.B.; Yoder, H.M.; Kiyokawa, H.; Kaestner, K.H.; Costa, R.H. The mouse Forkhead Box m1 transcription factor is essential for hepatoblast mitosis and development of intrahepatic bile ducts and vessels during liver morphogenesis. Dev. Biol. 2004, 276, 74-88. [CrossRef] [PubMed]

21. Kim, I.-M.; Ramakrishna, S.; Gusarova, G.A.; Yoder, H.M.; Costa, R.H.; Kalinichenko, V.V. The Forkhead Box M1 Transcription Factor Is Essential for Embryonic Development of Pulmonary Vasculature. J. Biol. Chem. 2005, 280, 22278-22286. [CrossRef]

22. Ramakrishna, S.; Kim, I.-M.; Petrovic, V.; Malin, D.; Wang, I.-C.; Kalin, T.V.; Meliton, L.; Zhao, Y.-Y.; Ackerson, T.; Qin, Y.; et al. Myocardium defects and ventricular hypoplasia in mice homozygous null for theForkhead Box m1 transcription factor. Dev. Dyn. 2007, 236, 1000-1013. [CrossRef] [PubMed]

23. Kalinichenko, V.V.; Lim, L.; Shin, B.; Costa, R.H. Differential expression of forkhead box transcription factors following butylated hydroxytoluene lung injury. Am. J. Physiol. Lung Cell. Mol. Physiol. 2001, 280, L695-L704. [CrossRef] [PubMed]

24. Zu, G.; Guo, J.; Zhou, T.; Che, N.; Liu, B.; Wang, D.; Zhang, X. The transcription factor FoxM1 activates Nurr1 to promote intestinal regeneration after ischemia/reperfusion injury. Exp. Mol. Med. 2019, 51,1-12. [CrossRef]

25. Chang-Panesso, M.; Kadyrov, F.F.; Lalli, M.; Wu, H.; Ikeda, S.; Kefaloyianni, E.; Abdelmageed, M.M.; Herrlich, A.; Kobayashi, A.; Humphreys, B.D. FOXM1 drives proximal tubule proliferation during repair from acute ischemic kidney injury. J. Clin. Investig. 2019, 129, 5501-5517. [CrossRef]

26. Chen, Z.; Li, L.; Xu, S.; Liu, Z.; Zhou, C.; Li, Z.; Liu, Y.; Wu, W.; Huang, Y.; Kuang, M.; et al. A Cdh1-FoxM1-Apc axis controls muscle development and regeneration. Cell Death Dis. 2020, 11, 180. [CrossRef]

27. Barger, C.J.; Branick, C.; Chee, L.; Karpf, A.R. Pan-Cancer Analyses Reveal Genomic Features of FOXM1 Overexpression in Cancer. Cancers 2019, 11, 251. [CrossRef] [PubMed]

28. Laoukili, J.; Stahl, M.; Medema, R.H. FoxM1: At the crossroads of ageing and cancer. Biochim. Biophys. Acta (BBA)-Bioenerg. 2007, 1775, 92-102. [CrossRef] 
29. Liao, G.-B.; Li, X.-Z.; Zeng, S.; Liu, C.; Yang, S.-M.; Yang, L.; Hu, C.-J.; Bai, J.-Y. Regulation of the master regulator FOXM1 in cancer. Cell Commun. Signal. 2018, 16, 1-15. [CrossRef]

30. Bell, D.; Berchuck, A.; Birrer, M.; Chien, J.; Cramer, D.W.; Dao, F.; Dhir, R.; DiSaia, P.; Gabra, H.; Glenn, P.; et al. Integrated genomic analyses of ovarian carcinoma. Nature 2011, 474, 609-615.

31. Zhang, X.; Zhang, L.; Du, Y.; Zheng, H.; Zhang, P.; Sun, Y.; Wang, Y.; Chen, J.; Ding, P.; Wang, N.; et al. A novel FOXM1 isoform, FOXM1D, promotes epithelial-mesenchymal transition and metastasis through ROCKs activation in colorectal cancer. Oncogene 2016, 36, 807-819. [CrossRef] [PubMed]

32. Gartel, A.L. FOXM1 in Cancer: Interactions and Vulnerabilities. Cancer Res. 2017, 77, 3135-3139. [CrossRef]

33. Kong, X.; Li, L.; Li, Z.; Le, X.; Huang, C.; Jia, Z.; Cui, J.; Huang, S.; Wang, L.; Xie, K. Dysregulated Expression of FOXM1 Isoforms Drives Progression of Pancreatic Cancer. Cancer Res. 2013, 73, 3987-3996. [CrossRef] [PubMed]

34. Wang, Q.; Zhang, P.; Zhang, W.; Zhang, X.; Chen, J.; Ding, P.; Li, L.; Lv, X.; Li, L.; Hu, W. PI3K activation is enhanced by FOXM1D binding to $\mathrm{p} 110$ and p85 subunits. Signal Transduct. Target. Ther. 2020, 5, 1-3. [CrossRef]

35. Zhang, W.; Zhang, X.; Huang, S.; Chen, J.; Ding, P.; Wang, Q.; Li, L.; Lv, X.; Li, L.; Zhang, P.; et al. FOXM1D potentiates PKM2-mediated tumor glycolysis and angiogenesis. Mol. Oncol. 2021, 15, 1466-1485. [CrossRef]

36. Barrett, C.L.; DeBoever, C.; Jepsen, K.; Saenz, C.C.; Carson, D.A.; Frazer, K.A. Systematic transcriptome analysis reveals tumorspecific isoforms for ovarian cancer diagnosis and therapy. Proc. Natl. Acad. Sci. USA 2015, 112, E3050-E3057. [CrossRef] [PubMed]

37. Park, H.J.; Wang, Z.; Costa, R.H.; Tyner, A.; Lau, L.F.; Raychaudhuri, P. An N-terminal inhibitory domain modulates activity of FoxM1 during cell cycle. Oncogene 2007, 27, 1696-1704. [CrossRef] [PubMed]

38. Golson, M.L.; Kaestner, K.H. Fox transcription factors: From development to disease. Development 2016, 143, 4558-4570. [CrossRef]

39. Littler, D.R.; Fernández, M.A.; Stein, A.; Hibbert, R.G.; Heidebrecht, T.; Aloy, P.; Medema, R.; Perrakis, A. Structure of the FoxM1 DNA-recognition domain bound to a promoter sequence. Nucleic Acids Res. 2010, 38, 4527-4538. [CrossRef]

40. A Sanders, D.; Ross-Innes, C.S.; Beraldi, D.; Carroll, J.S.; Balasubramanian, S. Genome-wide mapping of FOXM1 binding reveals co-binding with estrogen receptor alpha in breast cancer cells. Genome Biol. 2013, 14, R6. [CrossRef]

41. Chen, X.; Müller, G.A.; Quaas, M.; Fischer, M.; Han, N.; Stutchbury, B.; Sharrocks, A.D.; Engeland, K. The Forkhead Transcription Factor FOXM1 Controls Cell Cycle-Dependent Gene Expression through an Atypical Chromatin Binding Mechanism. Mol. Cell. Biol. 2012, 33, 227-236. [CrossRef]

42. Iness, A.; Litovchick, L. MuvB: A Key to Cell Cycle Control in Ovarian Cancer. Front. Oncol. 2018, 8, 223. [CrossRef]

43. Sanders, D.A.; Gormally, M.V.; Marsico, G.; Beraldi, D.; Tannahill, D.; Balasubramanian, S. FOXM1 binds directly to non-consensus sequences in the human genome. Genome Biol. 2015, 16, 1-23. [CrossRef]

44. Kang, K.; Choi, Y.; Kim, H.H.; Yoo, K.H.; Yu, S. Predicting FOXM1-Mediated Gene Regulation through the Analysis of GenomeWide FOXM1 Binding Sites in MCF-7, K562, SK-N-SH, GM12878 and ECC-1 Cell Lines. Int. J. Mol. Sci. 2020, 21, 6141. [CrossRef]

45. Mullen, D.J.; Yan, C.; Kang, D.S.; Zhou, B.; Borok, Z.; Marconett, C.N.; Farnham, P.J.; Offringa, I.A.; Rhie, S.K. TENET 2.0: Identification of key transcriptional regulators and enhancers in lung adenocarcinoma. PLoS Genet. 2020, 16, e1009023. [CrossRef]

46. Ye, H.; Holterman, A.X.; Yoo, K.W.; Franks, R.R.; Costa, R.H. Premature Expression of the Winged Helix Transcription Factor HFH-11B in Regenerating Mouse Liver Accelerates Hepatocyte Entry into S Phase. Mol. Cell. Biol. 1999, 19, 8570-8580. [CrossRef]

47. Wang, X.; Arceci, A.; Bird, K.; Mills, C.A.; Choudhury, R.; Kernan, J.L.; Zhou, C.; Bae-Jump, V.; Bowers, A.; Emanuele, M.J. VprBP/DCAF1 Regulates the Degradation and Nonproteolytic Activation of the Cell Cycle Transcription Factor FoxM1. Mol. Cell. Biol. 2017, 37, e00609-16. [CrossRef]

48. Jeffery, J.M.; Kalimutho, M.; Johansson, P.; Cardenas, D.G.; Kumar, R.; Khanna, K.K. FBXO31 protects against genomic instability by capping FOXM1 levels at the G2/M transition. Oncogene 2016, 36, 1012-1022. [CrossRef] [PubMed]

49. Anders, L.; Ke, N.; Hydbring, P.; Choi, Y.J.; Widlund, H.R.; Chick, J.M.; Zhai, H.; Vidal, M.; Gygi, S.P.; Braun, P.; et al. A systematic screen for CDK4/6 substrates links FOXM1 phosphorylation to senescence suppression in cancer cells. Cancer Cell 2011, 20, 620-634. [CrossRef] [PubMed]

50. Lüscher-Firzlaff, J.M.; Lilischkis, R.; Lüscher, B. Regulation of the transcription factor FOXM1c by Cyclin E/CDK2. FEBS Lett. 2006, 580, 1716-1722. [CrossRef] [PubMed]

51. Chen, Y.-J.; Dominguez-Brauer, C.; Wang, Z.; Asara, J.M.; Costa, R.H.; Tyner, A.L.; Lau, L.F.; Raychaudhuri, P. A Conserved Phosphorylation Site within the Forkhead Domain of FoxM1B Is Required for Its Activation by Cyclin-CDK1. J. Biol. Chem. 2009, 284, 30695-30707. [CrossRef]

52. Major, M.L.; Lepe, R.; Costa, R.H. Forkhead Box M1B Transcriptional Activity Requires Binding of Cdk-Cyclin Complexes for Phosphorylation-Dependent Recruitment of p300/CBP Coactivators. Mol. Cell. Biol. 2004, 24, 2649-2661. [CrossRef]

53. Fernández, M.A.; Halim, V.A.; Aprelia, M.; Mohammed, S.; Medema, R.H. Protein Phosphatase 2A (B55 $\alpha$ ) Prevents Premature Activation of Forkhead Transcription Factor FoxM1 by Antagonizing Cyclin A/Cyclin-dependent Kinase-mediated Phosphorylation. J. Biol. Chem. 2011, 286, 33029-33036. [CrossRef]

54. Laoukili, J.; Alvarez, M.; Meijer, L.A.T.; Stahl, M.; Mohammed, S.; Kleij, L.; Heck, A.J.R.; Medema, R.H. Activation of FoxM1 during G 2 Requires Cyclin A/Cdk-Dependent Relief of Autorepression by the FoxM1 N-Terminal Domain. Mol. Cell. Biol. 2008, 28, 3076-3087. [CrossRef] [PubMed]

55. Tan, Y.; Raychaudhuri, P.; Costa, R.H. Chk2 Mediates Stabilization of the FoxM1 Transcription Factor to Stimulate Expression of DNA Repair Genes. Mol. Cell. Biol. 2007, 27, 1007-1016. [CrossRef] [PubMed] 
56. Ma, R.Y.M.; Tong, T.H.K.; Cheung, A.M.S.; Tsang, A.C.C.; Leung, W.Y.; Yao, K.-M. Raf/MEK/MAPK signaling stimulates the nuclear translocation and transactivating activity of FOXM1c. J. Cell Sci. 2005, 118, 795-806. [CrossRef]

57. Fu, Z.; Malureanu, L.; Huang, J.; Wang, W.; Li, H.; Van Deursen, J.M.; Tindall, D.J.; Chen, J. Plk1-dependent phosphorylation of FoxM1 regulates a transcriptional programme required for mitotic progression. Nat. Cell Biol. 2008, 10, 1076-1082. [CrossRef] [PubMed]

58. Park, H.J.; Costa, R.H.; Lau, L.F.; Tyner, A.L.; Raychaudhuri, P. Anaphase-Promoting Complex/Cyclosome-Cdh1-Mediated Proteolysis of the Forkhead Box M1 Transcription Factor Is Critical for Regulated Entry into S Phase. Mol. Cell. Biol. 2008, 28, 5162-5171. [CrossRef] [PubMed]

59. Marceau, A.H.; Brison, C.M.; Nerli, S.; E Arsenault, H.; McShan, A.C.; Chen, E.; Lee, H.-W.; A Benanti, J.; Sgourakis, N.G.; Rubin, S.M. An order-to-disorder structural switch activates the FoxM1 transcription factor. eLife 2019, 8, 8. [CrossRef] [PubMed]

60. Wang, I.C.; Chen, Y.-J.; Hughes, D.; Petrovic, V.; Major, M.L.; Park, H.J.; Tan, Y.; Ackerson, T.; Cost, R.H. Forkhead Box M1 Regulates the Transcriptional Network of Genes Essential for Mitotic Progression and Genes Encoding the SCF (Skp2-Cks1) Ubiquitin Ligase. Mol. Cell. Biol. 2005, 25, 10875. [CrossRef] [PubMed]

61. Laoukili, J.; Kooistra, M.R.H.; Brás, A.; Kauw, J.; Kerkhoven, R.M.; Morrison, A.; Clevers, H.; Medema, R. FoxM1 is required for execution of the mitotic programme and chromosome stability. Nat. Cell Biol. 2005, 7, 126-136. [CrossRef]

62. Wonsey, D.R.; Follettie, M.T. Loss of the Forkhead Transcription Factor FoxM1 Causes Centrosome Amplification and Mitotic Catastrophe. Cancer Res. 2005, 65, 5181-5189. [CrossRef]

63. Schimmel, J.; Eifler, K.; Sigurðsson, J.O.; Cuijpers, S.A.; Hendriks, I.A.; Vries, M.V.-D.; Kelstrup, C.D.; Francavilla, C.; Medema, R.; Olsen, J.V.; et al. Uncovering SUMOylation Dynamics during Cell-Cycle Progression Reveals FoxM1 as a Key Mitotic SUMO Target Protein. Mol. Cell 2014, 53, 1053-1066. [CrossRef] [PubMed]

64. Wang, C.-M.; Liu, R.; Wang, L.; Nascimento, L.; Brennan, V.C.; Yang, W.-H. SUMOylation of FOXM1B Alters Its Transcriptional Activity on Regulation of MiR-200 Family and JNK1 in MCF7 Human Breast Cancer Cells. Int. J. Mol. Sci. 2014, 15, 10233-10251. [CrossRef]

65. Myatt, S.S.; Kongsema, M.; Man, C.W.-Y.; Kelly, D.J.; Gomes, A.R.; Khongkow, P.; Karunarathna, U.; Zona, S.; Langer, J.; Dunsby, C.; et al. SUMOylation inhibits FOXM1 activity and delays mitotic transition. Oncogene 2014, 33, 4316-4329. [CrossRef]

66. Jaiswal, N.; John, R.; Chand, V.; Nag, A. Oncogenic Human Papillomavirus 16E7 modulates SUMOylation of FoxM1b. Int. J. Biochem. Cell Biol. 2015, 58, 28-36. [CrossRef]

67. Zhang, J.; Yuan, C.; Wu, J.; Elsayed, Z.; Fu, Z. Polo-like Kinase 1-mediated Phosphorylation of Forkhead Box Protein M1b Antagonizes Its SUMOylation and Facilitates Its Mitotic Function. J. Biol. Chem. 2015, 290, 3708-3719. [CrossRef]

68. Lv, C.; Zhao, G.; Sun, X.; Wang, P.; Xie, N.; Luo, J.; Tong, T. Acetylation of FOXM1 is essential for its transactivation and tumor growth stimulation. Oncotarget 2016, 7, 60366-60382. [CrossRef]

69. Cohn, O.; Feldman, M.; Weil, L.; Kublanovsky, M.; Levy, D. Chromatin associated SETD3 negatively regulates VEGF expression. Sci. Rep. 2016, 6, 37115. [CrossRef]

70. Korver, W.; Schilham, M.W.; Moerer, P.; Hoff, M.J.V.D.; Dam, K.; Lamers, W.H.; Medema, R.; Clevers, H. Uncoupling of S phase and mitosis in cardiomyocytes and hepatocytes lacking the winged-helix transcription factor Trident. Curr. Biol. 1998, 8, 1327-1330. [CrossRef]

71. Kalin, T.V.; Ustiyan, V.; Kalinichenko, V.V. Multiple faces of FoxM1 transcription factor: Lessons from transgenic mouse models. Cell Cycle (Georgetown Tex) 2011, 10, 396-405. [CrossRef]

72. Ustiyan, V.; Wang, I.-C.; Ren, X.; Zhang, Y.; Snyder, J.; Xu, Y.; Wert, S.E.; Lessard, J.L.; Kalin, T.V.; Kalinichenko, V.V. Forkhead box M1 transcriptional factor is required for smooth muscle cells during embryonic development of blood vessels and esophagus. Dev. Biol. 2009, 336, 266-279. [CrossRef]

73. Kalin, T.V.; Wang, I.-C.; Meliton, L.; Zhang, Y.; Wert, S.E.; Ren, X.; Snyder, J.; Bell, S.M.; Graf, L.; Whitsett, J.A.; et al. Forkhead Box $\mathrm{m} 1$ transcription factor is required for perinatal lung function. Proc. Natl. Acad. Sci. USA 2008, 105, 19330-19335. [CrossRef]

74. Wang, I.-C.; Zhang, Y.; Snyder, J.; Sutherland, M.J.; Burhans, M.S.; Shannon, J.M.; Park, H.J.; Whitsett, J.A.; Kalinichenko, V.V. Increased expression of FoxM1 transcription factor in respiratory epithelium inhibits lung sacculation and causes Clara cell hyperplasia. Dev. Biol. 2010, 347, 301-314. [CrossRef]

75. Zhang, H.; Ackermann, A.M.; Gusarova, G.A.; Lowe, D.; Feng, X.; Kopsombut, U.G.; Costa, R.H.; Gannon, M. The FoxM1 Transcription Factor Is Required to Maintain Pancreatic $\beta$-Cell Mass. Mol. Endocrinol. 2006, 20, 1853-1866. [CrossRef]

76. Zhao, Y.-Y.; Gao, X.-P.; Zhao, Y.D.; Mirza, M.K.; Frey, R.S.; Kalinichenko, V.V.; Wang, I.C.; Costa, R.H.; Malik, A.B. Endothelial cell-restricted disruption of FoxM1 impairs endothelial repair following LPS-induced vascular injury. J. Clin. Investig. 2006, 116, 2333-2343. [CrossRef]

77. Mirza, M.K.; Sun, Y.; Zhao, Y.D.; Potula, H.-H.; Frey, R.S.; Vogel, S.M.; Malik, A.B.; Zhao, Y.-Y. FoxM1 regulates re-annealing of endothelial adherens junctions through transcriptional control of $\beta$-catenin expression. J. Exp. Med. 2010, 207, 1675-1685. [CrossRef]

78. Wang, X.; Kiyokawa, H.; Dennewitz, M.B.; Costa, R.H. The Forkhead Box m1b transcription factor is essential for hepatocyte DNA replication and mitosis during mouse liver regeneration. Proc. Natl. Acad. Sci. USA 2002, 99, 16881-16886. [CrossRef]

79. Wang, X.; Hung, N.; Costa, R.H. Earlier expression of the transcription factor HFH-11B diminishes induction of p21CIP1/WAF1 levels and accelerates mouse hepatocyte entry into S-phase following carbon tetrachloride liver injury. Hepatology 2001, 33, 1404-1414. [CrossRef] [PubMed] 
80. Wang, X.; Quail, E.; Hung, N.-J.; Tan, Y.; Ye, H.; Costa, R.H. Increased levels of forkhead box M1B transcription factor in transgenic mouse hepatocytes prevent age-related proliferation defects in regenerating liver. Proc. Natl. Acad. Sci. USA 2001, 98, 11468-11473. [CrossRef] [PubMed]

81. Kalinichenko, V.V.; Gusarova, G.A.; Tan, Y.; Wang, I.C.; Major, M.L.; Wang, X.; Yoder, H.M.; Costa, R.H. Ubiquitous expression of the forkhead box M1B transgene accelerates proliferation of distinct pulmonary cell types following lung injury. J. Biol. Chem. 2003, 278, 37888-37894. [CrossRef]

82. Ackermann, M.A.; Costa, R.H.; Gannon, M. Beta-cell proliferation, but not neogenesis, following $60 \%$ partial pancreatectomy is impaired in the absence of FoxM1. Diabetes 2008, 57, 3069-3077. [CrossRef]

83. Wang, I.-C.; Meliton, L.; Tretiakova, M.; Costa, R.H.; Kalinichenko, V.V.; Kalin, T.V. Transgenic expression of the forkhead box M1 transcription factor induces formation of lung tumors. Oncogene 2008, 27, 4137-4149. [CrossRef]

84. Yoshida, Y.; Wang, I.; Yoder, H.M.; Davidson, N.O.; Costa, R.H. The Forkhead Box M1 Transcription Factor Contributes to the Development and Growth of Mouse Colorectal Cancer. Gastroenterology 2007, 132, 1420-1431. [CrossRef]

85. Kalin, T.V.; Wang, I.-C.; Ackerson, T.J.; Major, M.L.; Detrisac, C.J.; Kalinichenko, V.V.; Lyubimov, A.; Costa, R.H. Increased Levels of the FoxM1 Transcription Factor Accelerate Development and Progression of Prostate Carcinomas in both TRAMP and LADY Transgenic Mice. Cancer Res. 2006, 66, 1712-1720. [CrossRef]

86. Milewski, D.; Balli, D.; Ustiyan, V.; Le, T.; Dienemann, H.; Warth, A.; Breuhahn, K.; Whitsett, J.A.; Kalinichenko, V.V.; Kalin, T.V. FOXM1 activates AGR2 and causes progression of lung adenomas into invasive mucinous adenocarcinomas. PLoS Genet. 2017, 13, e1007097. [CrossRef] [PubMed]

87. A Kalinina, O.; A Kalinin, S.; Polack, E.W.; Mikaelian, I.; Panda, S.; Costa, R.H.; Adami, G.R. Sustained hepatic expression of FoxM1B in transgenic mice has minimal effects on hepatocellular carcinoma development but increases cell proliferation rates in preneoplastic and early neoplastic lesions. Oncogene 2003, 22, 6266-6276. [CrossRef]

88. Kim, I.-M.; Ackerson, T.; Ramakrishna, S.; Tretiakova, M.; Wang, I.-C.; Kalin, T.V.; Major, M.L.; Gusarova, G.A.; Yoder, H.M.; Costa, R.H.; et al. The Forkhead Box $\mathrm{m} 1$ Transcription Factor Stimulates the Proliferation of Tumor Cells during Development of Lung Cancer. Cancer Res. 2006, 66, 2153-2161. [CrossRef] [PubMed]

89. Wang, I.-C.; Meliton, L.; Ren, X.; Zhang, Y.; Balli, D.; Snyder, J.; Whitsett, J.A.; Kalinichenko, V.V.; Kalin, T.V. Deletion of Forkhead Box M1 Transcription Factor from Respiratory Epithelial Cells Inhibits Pulmonary Tumorigenesis. PLoS ONE 2009, 4, e6609. [CrossRef] [PubMed]

90. Gusarova, G.A.; Wang, I.C.; Major, M.L.; Kalinichenko, V.V.; Ackerson, T.; Petrovic, V.; Costa, R.H. A cell-penetrating ARF peptide inhibitor of FoxM1 in mouse hepatocellular carcinoma treatment. J. Clin. Investig. 2007, 117, 99-111. [CrossRef]

91. Kalinichenko, V.V.; Major, M.L.; Wang, X.; Petrovic, V.; Kuechle, J.; Yoder, H.M.; Dennewitz, M.B.; Shin, B.; Datta, A.; Raychaudhuri, P.; et al. Foxm $1 b$ transcription factor is essential for development of hepatocellular carcinomas and is negatively regulated by the p19ARF tumor suppressor. Genes Dev. 2004, 18, 830-850. [CrossRef]

92. Perets, R.; Wyant, G.A.; Muto, K.W.; Bijron, J.G.; Poole, B.B.; Chin, K.T.; Chen, J.Y.H.; Ohman, A.W.; Stepule, C.D.; Kwak, S.; et al. Transformation of the Fallopian Tube Secretory Epithelium Leads to High-Grade Serous Ovarian Cancer in Brca;Tp53;Pten Models. Cancer Cell 2013, 24, 751-765. [CrossRef]

93. Zhai, Y.; Wu, R.; Kuick, R.; Sessine, M.S.; Schulman, S.; Green, M.; Fearon, E.R.; Cho, K.R. High-grade serous carcinomas arise in the mouse oviduct via defects linked to the human disease. J. Pathol. 2017, 243, 16-25. [CrossRef] [PubMed]

94. Kim, O.; Park, E.Y.; Klinkebiel, D.L.; Pack, S.D.; Shin, Y.-H.; Abdullaev, Z.; Emerson, R.E.; Coffey, D.M.; Kwon, S.Y.; Creighton, C.J.; et al. In vivo modeling of metastatic human high-grade serous ovarian cancer in mice. PLoS Genet. 2020, 16, e1008808. [CrossRef]

95. Siegel, R.; Ma, J.; Zou, Z.; Jemal, A. Cancer Statistics, 2014. CA Cancer J. Clin. 2014, 70, 7-30. [CrossRef]

96. Bray, F.; Ferlay, J.; Soerjomataram, I.; Siegel, R.L.; Torre, L.A.; Jemal, A. Global cancer statistics 2018: GLOBOCAN estimates of incidence and mortality worldwide for 36 cancers in 185 countries. CA Cancer J. Clin. 2018, 68, 394-424. [CrossRef]

97. Suh-Burgmann, E.J.; Alavi, M. Detection of early stage ovarian cancer in a large community cohort. Cancer Med. 2019, 8, 7133-7140. [CrossRef]

98. Wright, A.A.; Bohlke, K.; Armstrong, D.K.; Bookman, M.A.; Cliby, W.A.; Coleman, R.L.; Dizon, D.S.; Kash, J.J.; Meyer, L.A.; Moore, K.N.; et al. Neoadjuvant Chemotherapy for Newly Diagnosed, Advanced Ovarian Cancer: Society of Gynecologic Oncology and American Society of Clinical Oncology Clinical Practice Guideline. J. Clin. Oncol. 2016, 34, 3460-3473. [CrossRef]

99. Tew, W.P.; Lacchetti, C.; Ellis, A.; Maxian, K.; Banerjee, S.; Bookman, M.; Jones, M.B.; Lee, J.-M.; Lheureux, S.; Liu, J.F.; et al. PARP Inhibitors in the Management of Ovarian Cancer: ASCO Guideline. J. Clin. Oncol. 2020, 75, 739-741. [CrossRef]

100. Matulonis, U.A.; Sood, A.K.; Fallowfield, L.; Howitt, B.E.; Sehouli, J.; Karlan, B.Y. Ovarian Cancer. Nat. Rev. Dis. Primers 2016, 2, 16061. [CrossRef]

101. Baldwin, L.A.; Huang, B.; Miller, R.W.; Tucker, T.; Goodrich, S.T.; Podzielinski, I.; DeSimone, C.P.; Ueland, F.R.; Van Nagell, J.R.; Seamon, L.G. Ten-Year Relative Survival for Epithelial Ovarian Cancer. Obstet. Gynecol. 2012, 120, 612-618. [CrossRef]

102. Allemani, C.; Weir, H.K.; Carreira, H.; Harewood, R.; Spika, D.; Wang, X.-S.; Bannon, F.; Ahn, J.V.; Johnson, C.J.; Bonaventure, A.; et al. Global surveillance of cancer survival 1995-2009: Analysis of individual data for 25676887 patients from 279 population-based registries in 67 countries (CONCORD-2). Lancet 2015, 385, 977-1010. [CrossRef]

103. Kurman, R. Origin and molecular pathogenesis of ovarian high-grade serous carcinoma. Ann. Oncol. 2013, 24, x16-x21. [CrossRef] [PubMed] 
104. Kurman, R.J.; Shih, I.-M. The Dualistic Model of Ovarian Carcinogenesis: Revisited, revised, and expanded. Am. J. Pathol. 2016, 186, 733-747. [CrossRef] [PubMed]

105. Soong, T.R.; Howitt, B.E.; Horowitz, N.; Nucci, M.R.; Crum, C.P. The fallopian tube, "precursor escape" and narrowing the knowledge gap to the origins of high-grade serous carcinoma. Gynecol. Oncol. 2019, 152, 426-433. [CrossRef] [PubMed]

106. Perets, R.; Drapkin, R. It's Totally Tubular ... Riding the New Wave of Ovarian Cancer Research. Cancer Res. 2016, 76, 10-17. [CrossRef]

107. Klinkebiel, D.; Zhang, W.; Akers, S.N.; Odunsi, K.; Karpf, A.R. DNA Methylome Analyses Implicate Fallopian Tube Epithelia as the Origin for High-Grade Serous Ovarian Cancer. Mol. Cancer Res. 2016, 14, 787-794. [CrossRef]

108. Kindelberger, D.W.; Lee, Y.; Miron, A.; Hirsch, M.S.; Feltmate, C.; Medeiros, F.; Callahan, M.J.; Garner, E.O.; Gordon, R.W.; Birch, C.; et al. Intraepithelial Carcinoma of the Fimbria and Pelvic Serous Carcinoma: Evidence for a Causal Relationship. Am. J. Surg. Pathol. 2007, 31, 161-169. [CrossRef]

109. Lee, Y.; Miron, A.; Drapkin, R.; Nucci, M.R.; Medeiros, F.; Saleemuddin, A.; Garber, J.; Birch, C.; Mou, H.; Gordon, R.W.; et al. A candidate precursor to serous carcinoma that originates in the distal fallopian tube. J. Pathol. 2007, 211, 26-35. [CrossRef]

110. Levanon, K.; Crum, C.; Drapkin, R. New Insights into the Pathogenesis of Serous Ovarian Cancer and Its Clinical Impact. J. Clin. Oncol. 2008, 26, 5284-5293. [CrossRef]

111. Przybycin, C.G.; Kurman, R.J.; Ronnett, B.M.; Shih, I.-M.; Vang, R. Are All Pelvic (Nonuterine) Serous Carcinomas of Tubal Origin? Am. J. Surg. Pathol. 2010, 34, 1407-1416. [CrossRef]

112. Piek, J.M.J.; Van Diest, P.J.; Zweemer, R.P.; Jansen, J.W.; Poort-Keesom, R.J.J.; Menko, F.H.; Gille, J.J.P.; Jongsma, A.P.M.; Pals, G.; Kenemans, P. Dysplastic changes in prophylactically removed Fallopian tubes of women predisposed to developing ovarian cancer. J. Pathol. 2001, 195, 451-456. [CrossRef]

113. Leeper, K.; Garcia, R.; Swisher, E.; Goff, B.; Greer, B.; Paley, P. Pathologic Findings in Prophylactic Oophorectomy Specimens in High-Risk Women. Gynecol. Oncol. 2002, 87, 52-56. [CrossRef]

114. Medeiros, F.; Muto, M.G.; Lee, Y.; Elvin, A.J.; Callahan, M.J.; Feltmate, C.; E Garber, J.; Cramer, D.W.; Crum, C.P. The Tubal Fimbria Is a Preferred Site for Early Adenocarcinoma in Women with Familial Ovarian Cancer Syndrome. Am. J. Surg. Pathol. 2006, 30, 230-236. [CrossRef] [PubMed]

115. Karst, A.M.; Drapkin, R. Ovarian Cancer Pathogenesis: A Model in Evolution. J. Oncol. 2009, 2010, 1-13. [CrossRef]

116. Patch, A.-M.; Christie, E.; Etemadmoghadam, D.; Garsed, D.W.; George, J.; Fereday, S.; Nones, K.; Cowin, P.; Alsop, K.; The Australian Ovarian Cancer Study Group; et al. Whole-genome characterization of chemoresistant ovarian cancer. Nature 2015, 521, 489-494. [CrossRef]

117. Ottesen, A.M.; Skakkebæk, N.E.; Lundsteen, C.; Leffers, H.; Larsen, J.; Rajpert-De, M.E. High-resolution comparative genomic hybridization detects extra chromosome arm 12p material in most cases of carcinoma in situ adjacent to overt germ cell tumors, but not before the invasive tumor development. Genes Chromosomes Cancer 2003, 38, 117-125. [CrossRef] [PubMed]

118. Han, W.; Jung, E.-M.; Cho, J.; Lee, J.W.; Hwang, K.-T.; Yang, S.-J.; Kang, J.J.; Bae, J.-Y.; Jeon, Y.K.; Park, I.-A.; et al. DNA copy number alterations and expression of relevant genes in triple-negative breast cancer. Genes Chromosomes Cancer 2008, 47, 490-499. [CrossRef]

119. Green, M.R.; Aya, B.C.; Gandhi, M.K.; Lea, R.A.; Wellwood, J.; Wood, P.; Marlton, P.; Griffiths, L.R. Integrative genomic profiling reveals conserved genetic mechanisms for tumorigenesis in common entities of non-Hodgkin's lymphoma. Genes Chromosomes Cancer 2011, 50, 313-326. [CrossRef]

120. Yu, J.; Deshmukh, H.; Payton, J.E.; Dunham, C.; Scheithauer, B.W.; Tihan, T.; Prayson, R.A.; Guha, A.; Bridge, J.A.; Ferner, R.E.; et al. Array-Based Comparative Genomic Hybridization Identifies CDK4 and FOXM1 Alterations as Independent Predictors of Survival in Malignant Peripheral Nerve Sheath Tumor. Clin. Cancer Res. 2011, 17, 1924-1934. [CrossRef]

121. Liu, Y.; Melin, B.S.; Rajaraman, P.; Wang, Z.; Linet, M.; Shete, S.; Amos, C.I.; Lau, C.C.; Scheurer, M.; The Gliogene Consortium; et al. Insight in glioma susceptibility through an analysis of 6p22.3, 12p13.33-12.1, 17q22-23.2 and 18q23 SNP genotypes in familial and non-familial glioma. Qual. Life Res. 2012, 131, 1507-1517. [CrossRef]

122. Shi, J.; Chatterjee, N.; Rotunno, M.; Wang, Y.; Pesatori, A.C.; Consonni, D.; Li, P.; Wheeler, W.; Broderick, P.; Henrion, M.; et al. Inherited Variation at Chromosome 12p13.33, Including RAD52, Influences the Risk of Squamous Cell Lung Carcinoma. Cancer Discov. 2012, 2, 131-139. [CrossRef]

123. Delahaye-Sourdeix, M.; Oliver, J.; Timofeeva, M.N.; Gaborieau, V.; Johansson, M.; Chabrier, A.; Wozniak, M.B.; Brenner, D.R.; Vallée, M.P.; Anantharaman, D.; et al. The 12p13.33/RAD52 Locus and Genetic Susceptibility to Squamous Cell Cancers of Upper Aerodigestive Tract. PLoS ONE 2015, 10, e0117639. [CrossRef]

124. Singh, N.; Sahu, D.K.; Goel, M.; Kant, R.; Gupta, D.K. Retrospective analysis of FFPE based Wilms' Tumor samples through copy number and somatic mutation related Molecular Inversion Probe Based Array. Gene 2015, 565, 295-308. [CrossRef]

125. Shen, H.; Shih, J.; Hollern, D.P.; Wang, L.; Bowlby, R.; Tickoo, S.K.; Thorsson, V.; Mungall, A.J.; Newton, Y.; Hegde, A.M.; et al. Integrated Molecular Characterization of Testicular Germ Cell Tumors. Cell Rep. 2018, 23, 3392-3406. [CrossRef]

126. Follia, L.; Ferrero, G.; Mandili, G.; Beccuti, M.; Giordano, D.; Spadi, R.; Satolli, M.A.; Evangelista, A.; Katayama, H.; Hong, W.; et al. Integrative Analysis of Novel Metabolic Subtypes in Pancreatic Cancer Fosters New Prognostic Biomarkers. Front. Oncol. 2019, 9. [CrossRef] 
127. Barger, C.J.; Zhang, W.; Hillman, J.; Stablewski, A.B.; Higgins, M.J.; Vanderhyden, B.C.; Odunsi, K.; Karpf, A.R. Genetic determinants of FOXM1 overexpression in epithelial ovarian cancer and functional contribution to cell cycle progression. Oncotarget 2015, 6, 27613-27627. [CrossRef]

128. Paracchini, L.; Beltrame, L.; Grassi, T.; Inglesi, A.; Fruscio, R.; Landoni, F.; Ippolito, D.; Marchette, M.D.; Paderno, M.; Adorni, M.; et al. Genome-wide copy number alterations in circulating tumor DNA as a novel biomarker in high grade serous ovarian cancer patients. Clin. Cancer Res. 2020, 27, 2549-2559. [CrossRef]

129. Vang, R.; Levine, D.A.; Soslow, R.A.; Zaloudek, C.; Shih, I.-M.; Kurman, R.J. Molecular Alterations of TP53 are a Defining Feature of Ovarian High-Grade Serous Carcinoma: A Rereview of Cases Lacking TP53 Mutations in The Cancer Genome Atlas Ovarian Study. Int. J. Gynecol. Pathol. 2016, 35, 48-55. [CrossRef]

130. Brachova, P.; Thiel, K.W.; Leslie, K.K. The Consequence of Oncomorphic TP53 Mutations in Ovarian Cancer. Int. J. Mol. Sci. 2013, 14, 19257-19275. [CrossRef]

131. Petitjean, A.; Mathe, E.; Kato, S.; Ishioka, C.; Tavtigian, S.V.; Hainaut, P.; Olivier, M. Impact of mutant p53 functional properties onTP53mutation patterns and tumor phenotype: Lessons from recent developments in the IARC TP53 database. Hum. Mutat. 2007, 28, 622-629. [CrossRef]

132. Pandit, B.; Halasi, M.; Gartel, A.L. p53 negatively regulates expression of FoxM1. Cell Cycle (Georgetown Tex) 2009, 8, 3425-3427. [CrossRef]

133. Barsotti, A.M.; Prives, C. Pro-proliferative FoxM1 is a target of p53-mediated repression. Oncogene 2009, 28, 4295-4305. [CrossRef]

134. Elgaaen, B.V.; Olstad, O.K.; Sandvik, L.; Ødegaard, E.; Sauer, T.; Staff, A.C.; Gautvik, K.M. ZNF385B and VEGFA Are Strongly Differentially Expressed in Serous Ovarian Carcinomas and Correlate with Survival. PLoS ONE 2012, 7, e46317. [CrossRef]

135. Karthikeyan, S.; Lantvit, D.D.; Chae, D.H.; Burdette, J.E. Cadherin-6 type 2, K-cadherin (CDH6) is regulated by mutant p53 in the fallopian tube but is not expressed in the ovarian surface. Oncotarget 2016, 7, 69871-69882. [CrossRef]

136. Zhang, X.; Cheng, L.; Minn, K.; Madan, R.; Godwin, A.K.; Shridhar, V.; Chien, J. Targeting of mutant p53-induced FoxM1 with thiostrepton induces cytotoxicity and enhances carboplatin sensitivity in cancer cells. Oncotarget 2014, 5, 11365-11380. [CrossRef]

137. Rodgers, L.H.; Hainmhire, E.Ó.; Young, A.N.; Burdette, J.E. Loss of PAX8 in high-grade serous ovarian cancer reduces cell survival despite unique modes of action in the fallopian tube and ovarian surface epithelium. Oncotarget 2016, 7, 32785-32795. [CrossRef]

138. Ghannam-Shahbari, D.; Jacob, E.; Kakun, R.R.; Wasserman, T.; Korsensky, L.; Sternfeld, O.; Kagan, J.; Bublik, D.R.; Aviel-Ronen, S.; Levanon, K.; et al. PAX8 activates a p53-p21-dependent pro-proliferative effect in high grade serous ovarian carcinoma. Oncogene 2018, 37, 2213-2224. [CrossRef]

139. Tanaka, N.; Zhao, M.; Tang, L.; Patel, A.A.; Xi, Q.; Van, H.; Takahashi, H.; Osman, A.A.; Zhang, J.; Wang, J.; et al. Gain-of-function mutant p53 promotes the oncogenic potential of head and neck squamous cell carcinoma cells by targeting the transcription factors FOXO3a and FOXM1. Oncogene 2018, 37, 1279-1292. [CrossRef]

140. Sherr, C.J.; McCormick, F. The RB and p53 pathways in cancer. Cancer Cell 2002, 2, 103-112. [CrossRef]

141. Endsley, M.P.; Moyle-Heyrman, G.; Karthikeyan, S.; Lantvit, D.D.; Davis, D.A.; Wei, J.-J.; Burdette, J.E. Spontaneous Transformation of Murine Oviductal Epithelial Cells: A Model System to Investigate the Onset of Fallopian-Derived Tumors. Front. Oncol. 2015, 5. [CrossRef]

142. Millour, J.; De Olano, N.; Horimoto, Y.; Monteiro, L.J.; Langer, J.K.; Aligue, R.; Hajji, N.; Lam, E.W.-F. ATM and p53 Regulate FOXM1 Expression via E2F in Breast Cancer Epirubicin Treatment and Resistance. Mol. Cancer Ther. 2011, 10, 1046-1058. [CrossRef]

143. de Olano, N.; Koo, C.-Y.; Monteiro, L.J.; Pinto, P.H.; Gomes, A.R.; Aligue, R.; Lam, E.W.-F. The p38 MAPK-MK2 Axis Regulates E2F1 and FOXM1 Expression after Epirubicin Treatment. Mol. Cancer Res. 2012, 10, 1189-1202. [CrossRef]

144. Bollu, L.R.; Shepherd, J.; Zhao, D.; Ma, Y.; Tahaney, W.; Speers, C.; Mazumdar, A.; Mills, G.B.; Brown, P.H. Mutant P53 induces MELK expression by release of wild-type P53-dependent suppression of FOXM1. NPJ Breast Cancer 2020, 6, 1-12. [CrossRef]

145. Molinuevo, R.; Freije, A.; De Pedro, I.; Stoll, S.W.; Elder, J.T.; Gandarillas, A. FOXM1 allows human keratinocytes to bypass the oncogene-induced differentiation checkpoint in response to gain of MYC or loss of p53. Oncogene 2016, 36, 956-965. [CrossRef]

146. McGovern, U.B.; Francis, R.E.; Peck, B.; Guest, S.K.; Wang, J.; Myatt, S.S.; Krol, J.; Kwok, J.M.-M.; Polychronis, A.; Coombes, R.C.; et al. Gefitinib (Iressa) represses FOXM1 expression via FOXO3a in breast cancer. Mol. Cancer Ther. 2009, 8, 582-591. [CrossRef]

147. Delpuech, O.; Griffiths, B.; East, P.; Essafi, A.; Lam, E.W.-F.; Burgering, B.; Downward, J.; Schulze, A. Induction of Mxi1-SR $\alpha$ by FOXO3a Contributes to Repression of Myc-Dependent Gene Expression. Mol. Cell. Biol. 2007, 27, 4917-4930. [CrossRef]

148. Lam, E.W.-F.; Brosens, J.; Gomes, A.R.; Koo, C.-Y. Forkhead box proteins: Tuning forks for transcriptional harmony. Nat. Rev. Cancer 2013, 13, 482-495. [CrossRef]

149. Zou, Y.; Tsai, W.-B.; Cheng, C.-J.; Hsu, C.; Chung, Y.M.; Li, P.-C.; Lin, S.-H.; Hu, M.C.-T. Forkhead box transcription factor FOXO3a suppresses estrogen-dependent breast cancer cell proliferation and tumorigenesis. Breast Cancer Res. 2008, 10, R21. [CrossRef]

150. Karadedou, C.T.; Gomes, A.R.; Chen, J.; Petkovic, M.; Ho, K.-K.; Zwolinska, A.K.; Feltes, A.; Wong, S.Y.; Chan, K.Y.K.; Cheung, Y.-N.; et al. FOXO3a represses VEGF expression through FOXM1-dependent and -independent mechanisms in breast cancer. Oncogene 2011, 31, 1845-1858. [CrossRef]

151. Levanon, K.; Sapoznik, S.; Bahar-Shany, K.; Brand, H.; Shapira-Frommer, R.; Korach, J.; Hirsch, M.S.; Roh, M.H.; Miron, A.; Liu, J.F.; et al. FOXO3a loss is a frequent early event in high-grade pelvic serous carcinogenesis. Oncogene 2014, 33, 4424-4432. [CrossRef] 
152. Brunet, A.; Bonni, A.; Zigmond, M.J.; Lin, M.Z.; Juo, P.; Hu, L.S.; Anderson, M.J.; Arden, K.C.; Blenis, J.; E Greenberg, M. Akt Promotes Cell Survival by Phosphorylating and Inhibiting a Forkhead Transcription Factor. Cell 1999, 96, 857-868. [CrossRef]

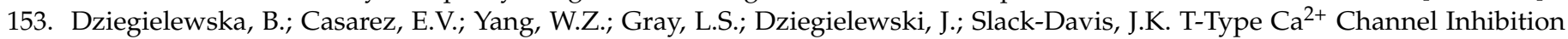
Sensitizes Ovarian Cancer to Carboplatin. Mol. Cancer Ther. 2016, 15, 460-470. [CrossRef] [PubMed]

154. Fan, Q.; Cai, Q.; Xu, Y. FOXM1 is a downstream target of LPA and YAP oncogenic signaling pathways in high grade serous ovarian cancer. Oncotarget 2015, 6, 27688-27699. [CrossRef] [PubMed]

155. Ikeda, Y.; Park, J.-H.; Miyamoto, T.; Takamatsu, N.; Kato, T.; Iwasa, A.; Okabe, S.; Imai, Y.; Fujiwara, K.; Nakamura, Y.; et al. T-LAK Cell-Originated Protein Kinase (TOPK) as a Prognostic Factor and a Potential Therapeutic Target in Ovarian Cancer. Clin. Cancer Res. 2016, 22, 6110-6117. [CrossRef] [PubMed]

156. Mizuno, T.; Murakami, H.; Fujii, M.; Ishiguro, F.; Tanaka, I.; Kondo, Y.; Akatsuka, S.; Toyokuni, S.; Yokoi, K.; Osada, H.; et al. YAP induces malignant mesothelioma cell proliferation by upregulating transcription of cell cycle-promoting genes. Oncogene 2012, 31, 5117-5122. [CrossRef] [PubMed]

157. Eisinger-Mathason, T.S.K.; Mucaj, V.; Biju, K.M.; Nakazawa, M.S.; Gohil, M.; Cash, T.P.; Yoon, S.S.; Skuli, N.; Park, K.M.; Gerecht, S.; et al. Deregulation of the Hippo pathway in soft-tissue sarcoma promotes FOXM1 expression and tumorigenesis. Proc. Natl. Acad. Sci. USA 2015, 112, E3402-E3411. [CrossRef] [PubMed]

158. Zhang, Z.; Ma, P.; Jing, Y.; Yan, Y.; Cai, M.-C.; Zhang, M.; Zhang, S.; Peng, H.; Ji, Z.-L.; Di, W.; et al. BET Bromodomain Inhibition as a Therapeutic Strategy in Ovarian Cancer by Downregulating FoxM1. Theranostics 2016, 6, 219-230. [CrossRef]

159. Momeny, M.; Eyvani, H.; Barghi, F.; Ghaffari, S.H.; Javadikooshesh, S.; Jamadi, R.H.; Esmaeili, F.; Alishahi, Z.; Zaghal, A.; Bashash, D.; et al. Inhibition of bromodomain and extraterminal domain reduces growth and invasive characteristics of chemoresistant ovarian carcinoma cells. Anti-Cancer Drugs 2018, 29, 1011-1020. [CrossRef]

160. Andrikopoulou, A.; Liontos, M.; Koutsoukos, K.; Dimopoulos, M.-A.; Zagouri, F. Clinical perspectives of BET inhibition in ovarian cancer. Cell. Oncol. 2021, 44, 237-249. [CrossRef]

161. Llauradó, M.; Majem, B.; Castellví, J.; Cabrera, S.; Gil-Moreno, A.; Reventós, J.; Ruiz, A. Analysis of Gene Expression Regulated by the ETV5 Transcription Factor in OV90 Ovarian Cancer Cells Identifies FOXM1 Overexpression in Ovarian Cancer. Mol. Cancer Res. 2012, 10, 914-924. [CrossRef] [PubMed]

162. Teh, M.-T.; Wong, S.-T.; Neill, G.W.; Ghali, L.R.; Philpott, M.P.; Quinn, A.G. FOXM1 is a downstream target of Gli1 in basal cell carcinomas. Cancer Res. 2002, 62, 4773-4780. [PubMed]

163. Douard, R.; Moutereau, S.; Pernet, P.; Chimingqi, M.; Allory, Y.; Manivet, P.; Conti, M.; Vaubourdolle, M.; Cugnenc, P.-H.; Loric, S. Sonic Hedgehog-dependent proliferation in a series of patients with colorectal cancer. Surgery 2006, 139, 665-670. [CrossRef]

164. Zhang, R.; Wu, J.; Ferrandon, S.; Glowacki, K.J.; Houghton, J.A. Targeting GLI by GANT61 involves mechanisms dependent on inhibition of both transcription and DNA licensing. Oncotarget 2016, 7, 80190-80207. [CrossRef] [PubMed]

165. Shi, C.; Huang, D.; Lu, N.; Chen, D.; Zhang, M.; Yan, Y.; Dengliang, H.; Lu, Q.; Lu, H.; Luo, S. Aberrantly activated Gli2-KIF20A axis is crucial for growth of hepatocellular carcinoma and predicts poor prognosis. Oncotarget 2016, 7, 26206-26219. [CrossRef]

166. Blanco-Bose, W.E.; Murphy, M.J.; Ehninger, A.; Offner, S.; Dubey, C.; Huang, W.; Moore, D.D.; Trumpp, A. C-Myc and its target FoxM1 are critical downstream effectors of constitutive androstane receptor (CAR) mediated direct liver hyperplasia. Hepatology 2008, 48, 1302-1311. [CrossRef]

167. Huynh, K.M.; Soh, J.-W.; Dash, R.; Sarkar, D.; Fisher, P.B.; Kang, D. FOXM1 expression mediates growth suppression during terminal differentiation of HO-1 human metastatic melanoma cells. J. Cell. Physiol. 2011, 226, 194-204. [CrossRef]

168. Pan, H.; Zhu, Y.; Wei, W.; Shao, S.; Rui, X. Transcription factor FoxM1 is the downstream target of c-Myc and contributes to the development of prostate cancer. World J. Surg. Oncol. 2018, 16, 59. [CrossRef]

169. Mencalha, A.L.; Binato, R.; Ferreira, G.M.; Du-Rocher, B.; Abdelhay, E. Forkhead Box M1 (FoxM1) Gene Is a New STAT3 Transcriptional Factor Target and Is Essential for Proliferation, Survival and DNA Repair of K562 Cell Line. PLoS ONE 2012, 7, e48160. [CrossRef] [PubMed]

170. Qian, J.; Luo, Y.; Gu, X.; Zhan, W.; Wang, X. Twist1 Promotes Gastric Cancer Cell Proliferation through Up-Regulation of FoxM1. PLoS ONE 2013, 8, e77625. [CrossRef] [PubMed]

171. Halasi, M.; Gartel, A.L. A novel mode of FoxM1 regulation: Positive auto-regulatory loop. Cell Cycle 2009, 8, 1966-1967. [CrossRef] [PubMed]

172. Cheng, X.-H.; Black, M.; Ustiyan, V.; Le, T.; Fulford, L.; Sridharan, A.; Medvedovic, M.; Kalinichenko, V.V.; Whitsett, J.A.; Kalin, T.V. SPDEF Inhibits Prostate Carcinogenesis by Disrupting a Positive Feedback Loop in Regulation of the Foxm1 Oncogene. PLoS Genet. 2014, 10, e1004656. [CrossRef] [PubMed]

173. Dai, B.; Gong, A.; Jing, Z.; Aldape, K.D.; Kang, S.-H.; Sawaya, R.; Huang, S. Forkhead Box M1 Is Regulated by Heat Shock Factor 1 and Promotes Glioma Cells Survival under Heat Shock Stress. J. Biol. Chem. 2013, 288, 1634-1642. [CrossRef]

174. Zhao, E.; Ding, J.; Xia, Y.; Liu, M.; Ye, B.; Choi, J.-H.; Yan, C.; Dong, Z.; Huang, S.; Zha, Y.; et al. KDM4C and ATF4 Cooperate in Transcriptional Control of Amino Acid Metabolism. Cell Rep. 2016, 14, 506-519. [CrossRef] [PubMed]

175. Park, H.J.; Carr, J.R.; Wang, Z.; Nogueira, V.; Hay, N.; Tyner, A.L.; Lau, L.F.; Costa, R.H.; Raychaudhuri, P. FoxM1, a critical regulator of oxidative stress during oncogenesis. EMBO J. 2009, 28, 2908-2918. [CrossRef]

176. Chen, P.-M.; Wu, T.-C.; Shieh, S.-H.; Wu, Y.-H.; Li, M.-C.; Sheu, G.-T.; Cheng, Y.-W.; Chen, C.-Y.; Lee, H. MnSOD Promotes Tumor Invasion via Upregulation of FoxM1-MMP2 Axis and Related with Poor Survival and Relapse in Lung Adenocarcinomas. Mol. Cancer Res. 2012, 11, 261-271. [CrossRef] 
177. Xia, L.; Mo, P.; Huang, W.; Zhang, L.; Wang, Y.; Zhu, H.; Tian, D.; Liu, J.; Chen, Z.; Zhang, Y.; et al. The TNF- $\alpha /$ ROS/HIF-1induced Upregulation of FoxMI Expression Promotes HCC Proliferation and Resistance to Apoptosis. Carcinogenesis 2012, 33, 2250-2259. [CrossRef]

178. Xia, L.-M.; Huang, W.-J.; Wang, B.; Liu, M.; Zhang, Q.; Yan, W.; Zhu, Q.; Luo, M.; Zhou, Z.-Z.; Tian, D.-A. Transcriptional up-regulation of FoxM1 in response to hypoxia is mediated by HIF-1. J. Cell. Biochem. 2009, 106, 247-256. [CrossRef]

179. Lu, J.; Wang, Z.; Cao, J.; Chen, Y.; Dong, Y. A novel and compact review on the role of oxidative stress in female reproduction. Reprod. Biol. Endocrinol. 2018, 16, 80. [CrossRef]

180. Statello, L.; Guo, C.-J.; Chen, L.-L.; Huarte, M. Gene regulation by long non-coding RNAs and its biological functions. Nat. Rev. Mol. Cell Biol. 2021, 22, 96-118. [CrossRef]

181. Razavi, Z.S.; Tajiknia, V.; Majidi, S.; Ghandali, M.; Mirzaei, H.R.; Rahimian, N.; Hamblin, M.R.; Mirzaei, H. Gynecologic cancers and non-coding RNAs: Epigenetic regulators with emerging roles. Crit. Rev. Oncol. 2021, 157, 103192. [CrossRef]

182. Kalathil, D.; John, S.; Nair, A.S. FOXM1 and Cancer: Faulty Cellular Signaling Derails Homeostasis. Front. Oncol. 2021, 10. [CrossRef]

183. Chen, Q.; Zhang, J.; He, Y.; Wang, Y. Hsa_circ_0061140 Knockdown Reverses FOXM1-Mediated Cell Growth and Metastasis in Ovarian Cancer through miR-370 Sponge Activity. Mol. Ther. Nucleic Acids 2018, 13, 55-63. [CrossRef] [PubMed]

184. Yi, K.; Hou, M.; Yuan, J.; Yang, L.; Zeng, X.; Xi, M.; Chen, J. LncRNA PVT1 epigenetically stabilizes and post-transcriptionally regulates FOXM1 by acting as a microRNA sponge and thus promotes malignant behaviors of ovarian cancer cells. Am. J. Transl. Res. 2020, 12, 2860-2874.

185. Duan, N.; Hu, X.; Yang, X.; Cheng, H.; Zhang, W. MicroRNA-370 directly targets FOXM1 to inhibit cell growth and metastasis in osteosarcoma cells. Int. J. Clin. Exp. Pathol. 2015, 8, 10250-10260.

186. Feng, Y.; Wang, L.; Zeng, J.; Shen, L.; Liang, X.; Yu, H.; Liu, S.; Liu, Z.; Sun, Y.; Li, W.; et al. FoxM1 is Overexpressed in Helicobacter pylori-Induced Gastric Carcinogenesis and Is Negatively Regulated by miR-370. Mol. Cancer Res. 2013, 11, 834-844. [CrossRef]

187. Zhang, X.; Zeng, J.; Zhou, M.; Li, B.; Zhang, Y.; Huang, T.; Wang, L.; Jia, J.; Chen, C. The tumor suppressive role of miRNA-370 by targeting FoxM1 in acute myeloid leukemia. Mol. Cancer 2012, 11, 56. [CrossRef]

188. Xu, M.-d.; Wang, Y.; Weng, W.; Wei, P.; Qi, P.; Zhang, Q.; Tan, C.; Ni, S.-j.; Dong, L.; Yang, Y.; et al. A Positive Feedback Loop of IncRNA-PVT1 and FOXM1 Facilitates Gastric Cancer Growth and Invasion. Clin. Cancer Res. 2017, 23, 2071-2080. [CrossRef]

189. Saleembhasha, A.; Mishra, S. Long non-coding RNAs as pan-cancer master gene regulators of associated protein-coding genes: A systems biology approach. PeerJ 2019, 7, e6388. [CrossRef]

190. Chen, J.; Li, Y.; Zheng, Q.; Bao, C.; He, J.; Chen, B.; Lyu, D.; Zheng, B.; Xu, Y.; Long, Z.; et al. Circular RNA profile identifies circPVT1 as a proliferative factor and prognostic marker in gastric cancer. Cancer Lett. 2017, 388, 208-219. [CrossRef]

191. Li, M.; Chi, C.; Zhou, L.; Chen, Y.; Tang, X. Circular PVT1 regulates cell proliferation and invasion via miR-149-5p/FOXM1 axis in ovarian cancer. J. Cancer 2021, 12, 611-621. [CrossRef] [PubMed]

192. Ke, Y.; Zhao, W.; Xiong, J.; Cao, R. miR-149 Inhibits Non-Small-Cell Lung Cancer Cells EMT by Targeting FOXM1. Biochem. Res. Int. 2013, 2013, 1-8. [CrossRef] [PubMed]

193. Luo, X.; Wang, G.-H.; Bian, Z.-L.; Li, X.-W.; Zhu, B.-Y.; Jin, C.-J.; Ju, S.-Q. Long non-coding RNA CCAL/miR-149/FOXM1 axis promotes metastasis in gastric cancer. Cell Death Dis. 2018, 9, 1-15. [CrossRef] [PubMed]

194. Tseng, Y.Y.; Moriarity, B.S.; Gong, W.; Akiyama, R.; Tiwari, A.; Kawakami, H.; Ronning, P.; Reuland, B.; Guenther, K.; Beadnell, T.C.; et al. PVT1 dependence in cancer with MYC copy-number increase. Nature 2014, 512, 82-86. [CrossRef] [PubMed]

195. Li, J.; Wang, Y.; Luo, J.; Fu, Z.; Ying, J.; Yu, Y.; Yu, W. miR-134 inhibits epithelial to mesenchymal transition by targeting FOXM1 in non-small cell lung cancer cells. FEBS Lett. 2012, 586, 3761-3765. [CrossRef]

196. Huang, L.; Wang, Z.-Y.; Pan, D.-D. Penicillin-binding protein 1A mutation-positive Helicobacter pylori promotes epithelialmesenchymal transition in gastric cancer via the suppression of microRNA. Int. J. Onco. L. 2019, 54, 916-928. [CrossRef]

197. Li, Y.; Wang, Z.; Li, J.; Sang, X. Diallyl disulfide suppresses FOXM1-mediated proliferation and invasion in osteosarcoma by upregulating miR. J. Cell. Biochem. 2019, 120, 7286-7296. [CrossRef] [PubMed]

198. Yuan, Y.; Wang, Q.; Cao, F.; Han, B.; Xu, L. MiRNA-134 suppresses esophageal squamous cell carcinoma progression by targeting FOXM1. Int. J. Clin. Exp. Pathol. 2019, 12, 2130-2138.

199. Wei, Y.; Wang, Z.; Zong, Y.; Deng, D.; Chen, P.; Lu, J. LncRNA MFI2-AS1 promotes HCC progression and metastasis by acting as a competing endogenous RNA of miR-134 to upregulate FOXM1 expression. Biomed. Pharmacother. 2020, 125, 109890. [CrossRef]

200. He, S.; Liao, B.; Deng, Y.; Su, C.; Tuo, J.; Liu, J.; Yao, S.; Xu, L. MiR-216b inhibits cell proliferation by targeting FOXM1 in cervical cancer cells and is associated with better prognosis. BMC Cancer 2017, 17, 1-12. [CrossRef] [PubMed]

201. Sun, M.; Wang, X.; Tu, C.; Wang, S.; Qu, J.; Xiao, S. microRNA-216b inhibits cell proliferation and migration in human melanoma by targeting FOXM1 in vitro and in vivo. Cell Biol. Int. 2017, 41, 1272-1282. [CrossRef]

202. Zhang, T.; Ma, G.; Zhang, Y.; Huo, H.; Zhao, Y. miR-216b inhibits glioma cell migration and invasion through suppression of FoxM1. Oncol. Rep. 2017, 38, 1751-1759. [CrossRef]

203. Wang, L.; Wang, Y.; Du, X.; Yao, Y.; Wang, L.; Jia, Y. MiR-216b suppresses cell proliferation, migration, invasion, and epithelialmesenchymal transition by regulating FOXM1 expression in human non-small cell lung cancer. OncoTargets Ther. 2019, 12, 2999-3009. [CrossRef] [PubMed] 
204. Hamurcu, Z.; Sener, E.F.; Taheri, S.; Nalbantoglu, U.; Kokcu, N.D.; Tahtasakal, R.; Cinar, V.; Guler, A.; Ozkul, Y.; Dönmez-Altuntas, H.; et al. MicroRNA profiling identifies Forkhead box transcription factor M1 (FOXM1) regulated miR-186 and miR-200b alterations in triple negative breast cancer. Cell. Signal. 2021, 83, 109979. [CrossRef]

205. Chan, D.W.; Hui, W.W.Y.; Cai, P.C.H.; Liu, M.X.; Yung, M.M.H.; Mak, C.S.L.; Leung, T.H.Y.; Chan, K.K.L.; Ngan, H.Y.S. Targeting GRB7/ERK/FOXM1 Signaling Pathway Impairs Aggressiveness of Ovarian Cancer Cells. PLoS ONE 2012, 7, e52578. [CrossRef]

206. Lok, G.T.M.; Chan, D.W.; Liu, V.W.S.; Hui, W.W.Y.; Leung, T.H.Y.; Yao, K.M.; Ngan, H.Y.S. Aberrant Activation of ERK/FOXM1 Signaling Cascade Triggers the Cell Migration/Invasion in Ovarian Cancer Cells. PLoS ONE 2011, 6, e23790. [CrossRef]

207. Zhang, Y.; Goodfellow, R.; Li, Y.; Yang, S.; Winters, C.J.; Thiel, K.W.; Leslie, K.K.; Yang, B. NEDD4 ubiquitin ligase is a putative oncogene in endometrial cancer that activates IGF-1R/PI3K/Akt signaling. Gynecol. Oncol. 2015, 139, 127-133. [CrossRef]

208. Wang, S.; Zhang, S.; Li, J.; Xu, X.; Weng, Y.; Zheng, M.; Ouyang, L.; Li, F. CXCL12-induced upregulation of FOXM1 expression promotes human glioblastoma cell invasion. Biochem. Biophys. Res. Commun. 2014, 447, 1-6. [CrossRef] [PubMed]

209. Liu, N.; Cui, W.; Jiang, X.; Zhang, Z.; Gnosa, S.; Ali, Z.; Jensen, L.; Jönsson, J.-I.; Blockhuys, S.; Lam, E.W.-F.; et al. The Critical Role of Dysregulated RhoB Signaling Pathway in Radioresistance of Colorectal Cancer. Int. J. Radiat. Oncol. 2019, 104, 1153-1164. [CrossRef] [PubMed]

210. Liu, G.; Sun, Y.; Ji, P.; Li, X.; Cogdell, D.; Yang, D.; Parker, K.B.C.; Shmulevich, I.; Chen, K.; Sood, A.K.; et al. MiR-506 suppresses proliferation and induces senescence by directly targeting the CDK4/6-FOXM1 axis in ovarian cancer. J. Pathol. 2014, 233, 308-318. [CrossRef]

211. Weichert, W.; Denkert, C.; Schmidt, M.; Gekeler, V.; Wolf, G.; Köbel, M.; Dietel, M.; Hauptmann, S. Polo-like kinase isoform expression is a prognostic factor in ovarian carcinoma. Br. J. Cancer 2004, 90, 815-821. [CrossRef]

212. Zhang, R.; Shi, H.; Ren, F.; Liu, H.; Zhang, M.; Deng, Y.; Li, X. Misregulation of polo-like protein kinase 1, P53 and P21WAF1 in epithelial ovarian cancer suggests poor prognosis. Oncol. Rep. 2015, 33, 1235-1242. [CrossRef]

213. Saldana, M.; Vandervorst, K.; Berg, A.L.; Lee, H.; Carraway, K.L. Otubain 1: A non-canonical deubiquitinase with an emerging role in cancer. Endocr. Relat. Cancer 2019, 26, R1-R14. [CrossRef] [PubMed]

214. Wang, Y.; Zhou, X.; Xu, M.; Weng, W.; Zhang, Q.; Yang, Y.; Wei, P.; Du, X. OTUB1-catalyzed deubiquitination of FOXM1 facilitates tumor progression and predicts a poor prognosis in ovarian cancer. Oncotarget 2016, 7, 36681-36697. [CrossRef]

215. Koboldt, D.C.; Fulton, R.S.; McLellan, M.D.; Schmidt, H.; Kalicki-Veizer, J.; McMichael, J.F.; Fulton, L.L.; Dooling, D.J.; Ding, L.; Mardis, E.R.; et al. Comprehensive molecular portraits of human breast tumours. Nature 2012, 490, 61-70.

216. Arceci, A.; Bonacci, T.; Wang, X.; Stewart, K.; Damrauer, J.S.; Hoadley, K.A.; Emanuele, M.J. FOXM1 Deubiquitination by USP21 Regulates Cell Cycle Progression and Paclitaxel Sensitivity in Basal-like Breast Cancer. Cell Rep. 2019, 26, 3076-3086.e6. [CrossRef]

217. Raychaudhuri, P.; Park, H.J. FoxM1: A Master Regulator of Tumor Metastasis. Cancer Res. 2011, 71, 4329-4333. [CrossRef]

218. Aytes, A.; Mitrofanova, A.; Lefebvre, C.; Alvarez, M.J.; Castillo-Martin, M.; Zheng, T.; Eastham, J.A.; Gopalan, A.; Pienta, K.J.; Shen, M.M.; et al. Cross-Species Regulatory Network Analysis Identifies a Synergistic Interaction between FOXM1 and CENPF that Drives Prostate Cancer Malignancy. Cancer Cell 2014, 25, 638-651. [CrossRef]

219. Halasi, M.; Gartel, A.L. FOX(M1) news-it is cancer. Mol. Cancer Ther. 2013, 12, 245-254. [CrossRef]

220. Fernández, M.A.; Medema, R.H. Novel functions of FoxM1: From molecular mechanisms to cancer therapy. Front. Oncol. 2013, 3, 30. [CrossRef]

221. Gentles, A.J.; Newman, A.; Liu, C.L.; Bratman, S.V.; Feng, W.; Kim, D.; Nair, V.S.; Xu, Y.; Khuong, A.; Hoang, C.D.; et al. The prognostic landscape of genes and infiltrating immune cells across human cancers. Nat. Med. 2015, 21, 938-945. [CrossRef]

222. Tassi, R.A.; Todeschini, P.; Siegel, E.R.; Calza, S.; Cappella, P.E.; Ardighieri, L.; Cadei, M.; Bugatti, M.; Romani, C.; Bandiera, E.; et al. FOXM1 expression is significantly associated with chemotherapy resistance and adverse prognosis in non-serous epithelial ovarian cancer patients. J. Exp. Clin. Cancer Res. 2017, 36, 1-18. [CrossRef]

223. Li, Y.; Guo, H.; Wang, Z.; Bu, H.; Wang, S.; Wang, H.; Fang, H.; Liu, Z.; Kong, B. Cyclin F and KIF20A, FOXM1 target genes, increase proliferation and invasion of ovarian cancer cells. Exp. Cell Res. 2020, 395, 112212. [CrossRef]

224. Chan, D.W.; Hui, W.W.Y.; Wang, J.J.; Yung, M.M.H.; Hui, L.M.N.; Qin, Y.; Liang, R.R.; Leung, T.H.Y.; Xu, D.; Chan, K.K.L.; et al. DLX1 acts as a crucial target of FOXM1 to promote ovarian cancer aggressiveness by enhancing TGF- $\beta /$ SMAD4 signaling. Oncogene 2017, 36, 1404-1416. [CrossRef]

225. Jin, C.; Liu, Z.; Li, Y.; Bu, H.; Wang, Y.; Xu, Y.; Qiu, C.; Yan, S.; Yuan, C.; Li, R.; et al. PCNA-associated factor P15PAF, targeted by FOXM1, predicts poor prognosis in high-grade serous ovarian cancer patients. Int. J. Cancer 2018, 143, 2973-2984. [CrossRef]

226. Zhang, Z.; Tu, K.; Liu, F.; Liang, M.; Yu, K.; Wang, Y.; Luo, Y.; Yang, B.; Qin, Y.; He, D.; et al. FoxM1 promotes the migration of ovarian cancer cell through KRT5 and KRT7. Gene 2020, 757, 144947. [CrossRef] [PubMed]

227. Paik, D.Y.; Janzen, D.M.; Schafenacker, A.M.; Velasco, V.S.; Shung, M.S.; Cheng, D.; Huang, J.; Witte, O.N.; Memarzadeh, S. Stem-Like Epithelial Cells Are Concentrated in the Distal End of the Fallopian Tube: A Site for Injury and Serous Cancer Initiation. Stem Cells 2012, 30, 2487-2497. [CrossRef]

228. An, Q.; Liu, T.; Wang, M.Y.; Yang, Y.J.; Zhang, Z.D.; Liu, Z.J.; Yang, B. KRT7 promotes epithelial-mesenchymal transition in ovarian cancer via the TGF- $\beta /$ Smad2/3 signaling pathway. Oncol. Rep. 2021, 45, 481-492. [CrossRef]

229. Pratheeshkumar, P.; Divya, S.P.; Parvathareddy, S.K.; Alhoshani, N.M.; Al-Badawi, I.A.; Tulbah, A.; Al-Dayel, F.; Siraj, A.K.; Al-Kuraya, K.S. FoxM1 and $\beta$-catenin predicts aggressiveness in Middle Eastern ovarian cancer and their co-targeting impairs the growth of ovarian cancer cells. Oncotarget 2017, 9, 3590-3604. [CrossRef] [PubMed] 
230. Nguyen, V.H.L.; Hough, R.; Bernaudo, S.; Peng, C. Wnt/ $\beta$-catenin signalling in ovarian cancer: Insights into its hyperactivation and function in tumorigenesis. J. Ovarian Res. 2019, 12, 1-17. [CrossRef]

231. Parashar, D.; Nair, B.; Geethadevi, A.; George, J.; Nair, A.; Tsaih, S.-W.; Kadamberi, I.P.; Nair, G.K.G.; Lu, Y.; Ramchandran, R.; et al. Peritoneal Spread of Ovarian Cancer Harbors Therapeutic Vulnerabilities Regulated by FOXM1 and EGFR/ERBB2 Signaling. Cancer Res. 2020, 80, 5554-5568. [CrossRef] [PubMed]

232. Zhou, J.; Wang, Y.; Wang, Y.; Yin, X.; He, Y.; Chen, L.; Wang, W.; Liu, T.; Di, W. FOXM1 Modulates Cisplatin Sensitivity by Regulating EXO1 in Ovarian Cancer. PLoS ONE 2014, 9, e96989. [CrossRef] [PubMed]

233. Fang, P.; Madden, J.; Neums, L.; Moulder, R.K.; Forrest, M.L.; Chien, J. Olaparib-induced Adaptive Response Is Disrupted by FOXM1 Targeting that Enhances Sensitivity to PARP Inhibition. Mol. Cancer Res. 2018, 16, 961-973. [CrossRef] [PubMed]

234. Brückner, L.; Reinshagen, A.; Hoang, N.; Höhn, A.; Lordick, F.; Bechmann, I.; Aktas, B.; Nel, I.; Kallendrusch, S. FOXM1 Inhibition in Ovarian Cancer Tissue Cultures Affects Individual Treatment Susceptibility Ex Vivo. Cancers 2021, 13, 956. [CrossRef] [PubMed]

235. Kwok, C.; Leung, M.; Qin, J.; Qin, Y.; Wang, J.; Lee, Y.; Yao, K.-M. The Forkhead box transcription factor FOXM1 is required for the maintenance of cell proliferation and protection against oxidative stress in human embryonic stem cells. Stem Cell Res. 2016, 16, 651-661. [CrossRef] [PubMed]

236. Yamamoto, Y.; Ning, G.; Howitt, B.E.; Mehra, K.; Wu, L.; Wang, X.; Hong, Y.; Kern, F.; Wei, T.S.; Zhang, T.; et al. In vitro and in vivo correlates of physiological and neoplastic human Fallopian tube stem cells. J. Pathol. 2016, 238, 519-530. [CrossRef] [PubMed]

237. Wen, N.; Wang, Y.; Wen, L.; Zhao, S.-H.; Ai, Z.-H.; Wang, Y.; Wu, B.; Lu, H.-X.; Yang, H.; Liu, W.-C.; et al. Overexpression of FOXM1 predicts poor prognosis and promotes cancer cell proliferation, migration and invasion in epithelial ovarian cancer. $J$. Transl. Med. 2014, 12, 134. [CrossRef] [PubMed]

238. Liu, J.; Meng, H.; Li, S.; Shen, Y.; Wang, H.; Shan, W.; Qiu, J.; Zhang, J.; Cheng, W. Identification of Potential Biomarkers in Association with Progression and Prognosis in Epithelial Ovarian Cancer by Integrated Bioinformatics Analysis. Front. Genet. 2019, 10. [CrossRef]

239. Zhao, F.; Siu, M.K.Y.; Jiang, L.; Tam, K.F.; Ngan, H.Y.S.; Le, X.F.; Wong, O.G.W.; Wong, E.S.Y.; Gomes, A.R.; Bella, L.; et al. Overexpression of Forkhead Box Protein M1 (FOXM1) in Ovarian Cancer Correlates with Poor Patient Survival and Contributes to Paclitaxel Resistance. PLoS ONE 2014, 9, e113478. [CrossRef]

240. Chiu, W.-T.; Huang, Y.-F.; Tsai, H.-Y.; Chen, C.-C.; Chang, C.-H.; Huang, S.-C.; Hsu, K.-F.; Chou, C.-Y. FOXM1 confers to epithelial-mesenchymal transition, stemness and chemoresistance in epithelial ovarian carcinoma cells. Oncotarget 2014, 6, 2349-2365. [CrossRef]

241. Mekhdjian, A.H.; Kai, F.; Rubashkin, M.G.; Prahl, L.; Przybyla, L.M.; McGregor, A.L.; Bell, E.S.; Barnes, J.M.; Dufort, C.C.; Ou, G.; et al. Integrin-mediated traction force enhances paxillin molecular associations and adhesion dynamics that increase the invasiveness of tumor cells into a three-dimensional extracellular matrix. Mol. Biol. Cell 2017, 28, 1467-1488. [CrossRef] [PubMed]

242. Yeh, H.-W.; Lee, S.-S.; Chang, C.-Y.; Lang, Y.-D.; Jou, Y.-S. A New Switch for TGF $\beta$ in Cancer. Cancer Res. 2019, 79, 3797-3805. [CrossRef] [PubMed]

243. Zhang, N.; Wei, P.; Gong, A.; Chiu, W.-T.; Lee, H.-T.; Colman, H.; Huang, H.; Xue, J.; Liu, M.; Wang, Y.; et al. FoxM1 Promotes $\beta$-Catenin Nuclear Localization and Controls Wnt Target-Gene Expression and Glioma Tumorigenesis. Cancer Cell 2011, 20, 427-442. [CrossRef]

244. Wierstra, I. The transcription factor FOXM1c binds to and transactivates the promoter of the tumor suppressor gene E-cadherin. Cell Cycle 2011, 10, 760-766. [CrossRef]

245. Rodriguez, F.J.; Lewis-Tuffin, L.J.; Anastasiadis, P.Z. E-cadherin's dark side: Possible role in tumor progression. Biochim. Biophys. Acta (BBA)-Rev. Cancer 2012, 1826, 23-31. [CrossRef] [PubMed]

246. Roque, R.J.; Sousa, F.C.; Figueiredo-Dias, M. Epithelial-mesenchymal interconversions in ovarian cancer: The levels and functions of E-cadherin in intraabdominal dissemination. Oncol. Rev. 2020, 14, 475. [CrossRef] [PubMed]

247. Trillsch, F.; Kuerti, S.; Eulenburg, C.; Burandt, E.; Woelber, L.; Prieske, K.; Eylmann, K.; Oliveira-Ferrer, L.; Milde-Langosch, K.; Mahner, S. E-Cadherin fragments as potential mediators for peritoneal metastasis in advanced epithelial ovarian cancer. Br. J. Cancer 2016, 114, 213-220. [CrossRef]

248. Wells, A.; Yates, C.; Shepard, C.R. E-cadherin as an indicator of mesenchymal to epithelial reverting transitions during the metastatic seeding of disseminated carcinomas. Clin. Exp. Metastasis 2008, 25, 621-628. [CrossRef]

249. Yang, Y.; Yang, Y.; Yang, J.; Zhao, X.; Wei, X. Tumor Microenvironment in Ovarian Cancer: Function and Therapeutic Strategy. Front. Cell Dev. Biol. 2020, 8, 758. [CrossRef]

250. Balli, D.; Ren, X.; Chou, F.-S.; Cross, E.; Zhang, Y.; Kalinichenko, V.V.; Kalin, T.V. Foxm1 transcription factor is required for macrophage migration during lung inflammation and tumor formation. Oncogene 2011, 31, 3875-3888. [CrossRef]

251. Galbo, P.M.; Zang, X.; Zheng, D. Molecular Features of Cancer-associated Fibroblast Subtypes and their Implication on Cancer Pathogenesis, Prognosis, and Immunotherapy Resistance. Clin. Cancer Res. 2021, 27, 2636-2647. [CrossRef]

252. Sun, L.; Wang, Y.; Wang, L.; Yao, B.; Chen, T.; Li, Q.; Liu, Z.; Liu, R.; Niu, Y.; Song, T.; et al. Resolvin D1 prevents epithelialmesenchymal transition and reduces the stemness features of hepatocellular carcinoma by inhibiting paracrine of cancerassociated fibroblast-derived COMP. J. Exp. Clin. Cancer Res. 2019, 38, 1-17. [CrossRef] 
253. Maniati, E.; Berlato, C.; Gopinathan, G.; Heath, O.; Kotantaki, P.; Lakhani, A.; McDermott, J.; Pegrum, C.; Delaine-Smith, R.M.; Pearce, O.M.; et al. Mouse Ovarian Cancer Models Recapitulate the Human Tumor Microenvironment and Patient Response to Treatment. Cell Rep. 2020, 30, 525-540.e7. [CrossRef]

254. Iyer, S.; Zhang, S.; Yucel, S.; Horn, H.; Smith, S.G.; Reinhardt, F.; Hoefsmit, E.; Assatova, B.; Casado, J.; Meinsohn, M.-C.; et al. Genetically Defined Syngeneic Mouse Models of Ovarian Cancer as Tools for the Discovery of Combination Immunotherapy. Cancer Discov. 2021, 11, 384-407. [CrossRef]

255. Zona, S.; Bella, L.; Burton, M.J.; de Moraes, G.N.; Lam, E.W.-F. FOXM1: An emerging master regulator of DNA damage response and genotoxic agent resistance. Biochim. et Biophys. Acta (BBA)-Bioenerg. 2014, 1839, 1316-1322. [CrossRef] [PubMed]

256. Barger, C.J.; Chee, L.; Albahrani, M.; Munoz-Trujillo, C.; Boghean, L.; Branick, C.; Odunsi, K.; Drapkin, R.; Zou, L.; Karpf, A.R. Author response: Co-regulation and function of FOXM1/RHNO1 bidirectional genes in cancer. eLife 2021, 10, e55070. [CrossRef] [PubMed]

257. Wu, Y.; Xia, L.; Guo, Q.; Zhu, J.; Deng, Y.; Wu, X. Identification of Chemoresistance-Associated Key Genes and Pathways in High-Grade Serous Ovarian Cancer by Bioinformatics Analyses. Cancer Manag. Res. 2020, 12, 5213-5223. [CrossRef]

258. Gartel, A.L. FoxM1 inhibitors as potential anticancer drugs. Expert Opin. Ther. Targets 2008, 12, 663-665. [CrossRef] [PubMed]

259. Kwok, J.M.-M.; Myatt, S.S.; Marson, C.M.; Coombes, R.C.; Constantinidou, D.; Lam, E.W.-F. Thiostrepton selectively targets breast cancer cells through inhibition of forkhead box M1 expression. Mol. Cancer Ther. 2008, 7, 2022-2032. [CrossRef]

260. Westhoff, G.L.; Chen, Y.; Teng, N.N. Targeting Foxm1 Improves Cytotoxicity of Paclitaxel and Cisplatinum in Platinum-Resistant Ovarian Cancer. Int. J. Gynecol. Cancer 2017, 27, 887-894. [CrossRef]

261. Bhat, U.G.; Halasi, M.; Gartel, A.L. FoxM1 Is a General Target for Proteasome Inhibitors. PLoS ONE 2009, 4, e6593. [CrossRef] [PubMed]

262. Hardy, L.R.; Pergande, M.; Esparza, K.; Heath, K.N.; Önyüksel, H.; Cologna, S.M.; Burdette, J.E. Proteomic analysis reveals a role for PAX8 in peritoneal colonization of high grade serous ovarian cancer that can be targeted with micelle encapsulated thiostrepton. Oncogene 2019, 38, 6003-6016. [CrossRef] [PubMed]

263. Zhang, L.; Ging, N.C.; Komoda, T.; Hanada, T.; Suzuki, T.; Watanabe, K. Antibiotic susceptibility of mammalian mitochondrial translation. FEBS Lett. 2005, 579, 6423-6427. [CrossRef] [PubMed]

264. Carr, J.R.; Park, H.J.; Wang, Z.; Kiefer, M.M.; Raychaudhuri, P. FoxM1 Mediates Resistance to Herceptin and Paclitaxel. Cancer Res. 2010, 70, 5054-5063. [CrossRef] [PubMed]

265. Yang, N.; Wang, C.; Wang, J.; Wang, Z.; Huang, D.; Yan, M.; Kamran, M.; Liu, Q.; Xu, B. Aurora kinase A stabilizes FOXM1 to enhance paclitaxel resistance in triple-negative breast cancer. J. Cell. Mol. Med. 2019, 23, 6442-6453. [CrossRef]

266. Okada, K.; Fujiwara, Y.; Takahashi, T.; Nakamura, Y.; Takiguchi, S.; Nakajima, K.; Miyata, H.; Yamasaki, M.; Kurokawa, Y.; Mori, M.; et al. Overexpression of Forkhead Box M1 Transcription Factor (FOXM1) is a Potential Prognostic Marker and Enhances Chemoresistance for Docetaxel in Gastric Cancer. Ann. Surg. Oncol. 2013, 20, 1035-1043. [CrossRef]

267. Li, X.; Qiu, W.; Liu, B.; Yao, R.; Liu, S.; Yao, Y.; Liang, J. Forkhead box transcription factor 1 expression in gastric cancer: FOXM1 is a poor prognostic factor and mediates resistance to docetaxel. J. Transl. Med. 2013, 11, 204. [CrossRef]

268. Li, X.; Yao, R.; Yue, L.; Qiu, W.; Qi, W.; Liu, S.; Yao, Y.; Liang, J. FOXM 1 mediates resistance to docetaxel in gastric cancer via up-regulating Stathmin. J. Cell. Mol. Med. 2014, 18, 811-823. [CrossRef]

269. Huang, X.; Qin, J.; Lu, S. Up-regulation of miR-877 induced by paclitaxel inhibits hepatocellular carcinoma cell proliferation though targeting FOXM1. Int. J. Clin. Exp. Pathol. 2015, 8, 1515-1524.

270. Yuan, B.; Liu, Y.; Yu, X.; Yin, L.; Peng, Y.; Gao, Y.; Zhu, Q.; Cao, T.; Yang, Y.; Fan, X.; et al. FOXM1 contributes to taxane resistance by regulating UHRF1-controlled cancer cell stemness. Cell Death Dis. 2018, 9, 1-11. [CrossRef]

271. Hou, Y.; Zhu, Q.; Li, Z.; Peng, Y.; Yu, X.; Yuan, B.; Liu, Y.; Liu, Y.; Yin, L.; Peng, Y.; et al. The FOXM1-ABCC5 axis contributes to paclitaxel resistance in nasopharyngeal carcinoma cells. Cell Death Dis. 2017, 8, e2659. [CrossRef]

272. Ahmed, M.; Uddin, S.; Hussain, A.R.; Alyan, A.; Jehan, Z.; Al-Dayel, F.; Al-Nuaim, A.; Al-Sobhi, S.; Amin, T.; Bavi, P.; et al. FoxM1 and Its Association with Matrix Metalloproteinases (MMP) Signaling Pathway in Papillary Thyroid Carcinoma. J. Clin. Endocrinol. Metab. 2012, 97, E1-E13. [CrossRef]

273. Jiang, L.; Wang, P.; Chen, L.; Chen, H. Down-regulation of FoxM1 by thiostrepton or small interfering RNA inhibits proliferation, transformation ability and angiogenesis, and induces apoptosis of nasopharyngeal carcinoma cells. Int. J. Clin. Exp. Pathol. 2014, 7, 5450-5460.

274. de Nestal, M.G.; Delbue, D.; Silva, K.L.; Robaina, M.C.; Khongkow, P.; Gomes, A.R.; Zona, S.; Crocamo, S.; Mencalha, A.L.; Magalhães, L.M.; et al. FOXM1 targets XIAP and Survivin to modulate breast cancer survival and chemoresistance. Cell. Signal. 2015, 27, 2496-2505. [CrossRef]

275. Jiang, L.; Wu, X.; Wang, P.; Wen, T.; Yu, C.; Wei, L.; Chen, H. Targeting FoxM1 by thiostrepton inhibits growth and induces apoptosis of laryngeal squamous cell carcinoma. J. Cancer Res. Clin. Oncol. 2014, 141, 971-981. [CrossRef]

276. Fulda, S.; Vucic, D. Targeting IAP proteins for therapeutic intervention in cancer. Nat. Rev. Drug Discov. 2012, 11, 109-124. [CrossRef] [PubMed]

277. Aponte, P.M.; Caicedo, A. Stemness in Cancer: Stem Cells, Cancer Stem Cells, and Their Microenvironment. Stem Cells Int. 2017, 2017, 1-17. [CrossRef] [PubMed]

278. Sabini, C.; Sorbi, F.; Cunnea, P.; Fotopoulou, C. Ovarian cancer stem cells: Ready for prime time? Arch. Gynecol. Obstet. 2020, 301, 895-899. [CrossRef] [PubMed] 
279. Muñoz-Galván, S.; Carnero, A. Targeting Cancer Stem Cells to Overcome Therapy Resistance in Ovarian Cancer. Cells 2020, 9, 1402. [CrossRef] [PubMed]

280. Teh, M.-T. FOXM1 coming of age: Time for translation into clinical benefits? Front. Oncol. 2012, 2, 146. [CrossRef] [PubMed]

281. Xie, Z.; Tan, G.; Ding, M.; Dong, D.; Chen, T.; Meng, X.; Huang, X.; Tan, Y. Foxm1 transcription factor is required for maintenance of pluripotency of P19 embryonal carcinoma cells. Nucleic Acids Res. 2010, 38, 8027-8038. [CrossRef]

282. Kelleher, F.C.; O'Sullivan, H. FOXM1 in sarcoma: Role in cell cycle, pluripotency genes and stem cell pathways. Oncotarget 2016, 7, 42792-42804. [CrossRef]

283. Wang, Z.; Park, H.J.; Carr, J.R.; Chen, Y.-J.; Zheng, Y.; Li, J.; Tyner, A.L.; Costa, R.H.; Bagchi, S.; Raychaudhuri, P. FoxM1 in Tumorigenicity of the Neuroblastoma Cells and Renewal of the Neural Progenitors. Cancer Res. 2011, 71, 4292-4302. [CrossRef]

284. Ning, Y.-X.; Li, Q.-X.; Ren, K.-Q.; Quan, M.-F.; Cao, J.-G. 7-difluoromethoxyl-5,4'-di-n-octyl genistein inhibits ovarian cancer stem cell characteristics through the downregulation of FOXM1. Oncol. Lett. 2014, 8, 295-300. [CrossRef]

285. Young, M.-J.; Wu, Y.-H.; Chiu, W.-T.; Weng, T.-Y.; Huang, Y.-F.; Chou, C.-Y. All-trans retinoic acid downregulates ALDH1-mediated stemness and inhibits tumour formation in ovarian cancer cells. Carcinogenesis 2015, 36, 498-507. [CrossRef]

286. Li, M.; Yang, J.; Zhou, W.; Ren, Y.; Wang, X.; Chen, H.; Zhang, J.; Chen, J.; Sun, Y.; Cui, L.; et al. Activation of an AKT/FOXM1/STMN1 pathway drives resistance to tyrosine kinase inhibitors in lung cancer. Br. J. Cancer 2017, 117, 974983. [CrossRef] [PubMed]

287. Fu, Z.; Cao, X.; Yang, Y.; Song, Z.; Zhang, J.; Wang, Z. Upregulation of FoxM1 by MnSOD Overexpression Contributes to Cancer Stem-Like Cell Characteristics in the Lung Cancer H460 Cell Line. Technol. Cancer Res. Treat. 2018, 17. [CrossRef] [PubMed]

288. Yuan, Q.; Wen, M.; Xu, C.; Chen, A.; Qiu, Y.-B.; Cao, J.-G.; Zhang, J.-S.; Song, Z.-W. 8-bromo-7-methoxychrysin targets NF-kB and FoxM1 to inhibit lung cancer stem cells induced by pro-inflammatory factors. J. Cancer 2019, 10, 5244-5255. [CrossRef] [PubMed]

289. Kopanja, D.; Pandey, A.; Kiefer, M.; Wang, Z.; Chandan, N.; Carr, J.R.; Franks, R.; Yu, D.-Y.; Guzman, G.; Maker, A.; et al. Essential roles of FoxM1 in Ras-induced liver cancer progression and in cancer cells with stem cell features. J. Hepatol. 2015, 63, 429-436. [CrossRef] [PubMed]

290. Cao, X.; Liu, L.; Yuan, Q.; Li, X.; Cui, Y.; Ren, K.; Zou, C.; Chen, A.; Xu, C.; Qiu, Y.; et al. Isovitexin reduces carcinogenicity and stemness in hepatic carcinoma stem-like cells by modulating MnSOD and FoxM1. J. Exp. Clin. Cancer Res. 2019, 38, 1-18. [CrossRef]

291. Nakano, I. Transcription factors as master regulator for cancer stemness: Remove milk from fox? Expert Rev. Anticancer. Ther. 2014, 14, 873-875. [CrossRef] [PubMed]

292. Lee, Y.; Kim, K.H.; Kim, D.G.; Cho, H.J.; Kim, Y.; Rheey, J.; Shin, K.; Seo, Y.J.; Choi, Y.-S.; Lee, J.-I.; et al. FoxM1 Promotes Stemness and Radio-Resistance of Glioblastoma by Regulating the Master Stem Cell Regulator Sox2. PLoS ONE 2015, 10, e0137703. [CrossRef] [PubMed]

293. Li, F.; Jin, D.; Guan, L.; Zhang, C.-C.; Wu, T.; Wang, Y.-J.; Gao, D. CEP55 promoted the migration, invasion and neuroshpere formation of the glioma cell line. UNeurosci. Lett. 2019, 705, 80-86. [CrossRef]

294. De Luca, A.; Fiorillo, M.; Peiris-Pagès, M.; Ozsvari, B.; Smith, D.L.; Sanchez-Alvarez, R.; Martinez-Outschoorn, U.E.; Cappello, A.R.; Pezzi, V.; Lisanti, M.P.; et al. Mitochondrial biogenesis is required for the anchorage-independent survival and propagation of stem-like cancer cells. Oncotarget 2015, 6, 14777. [CrossRef]

295. Song, I.-S.; Jeong, Y.J.; Jeong, S.H.; Heo, H.J.; Kim, H.K.; Bae, K.B.; Park, Y.-H.; Kim, S.U.; Kim, J.-M.; Kim, N.; et al. FOXM1-Induced PRX3 Regulates Stemness and Survival of Colon Cancer Cells via Maintenance of Mitochondrial Function. Gastroenterology 2015, 149, 1006-1016.e9. [CrossRef]

296. Song, I.-S.; Jeong, Y.J.; Seo, Y.J.; Byun, J.M.; Kim, Y.N.; Jeong, D.H.; Han, J.; Kim, K.T.; Jang, S.-W. Peroxiredoxin 3 maintains the survival of endometrial cancer stem cells by regulating oxidative stress. Oncotarget 2017, 8, 92788-92800. [CrossRef]

297. Chen, Y.; Meng, L.; Yu, Q.; Dong, D.; Tan, G.; Huang, X.; Tan, Y. The miR-134 attenuates the expression of transcription factor FOXM1 during pluripotent NT2/D1 embryonal carcinoma cell differentiation. Exp. Cell Res. 2015, 330, 442-450. [CrossRef]

298. Ciriello, G.; Miller, M.L.; Aksoy, B.A.; Senbabaoglu, Y.; Schultz, N.; Sander, C. Emerging landscape of oncogenic signatures across human cancers. Nat. Genet. 2013, 45, 1127-1133. [CrossRef]

299. Carter, S.L.; Eklund, A.C.; Kohane, I.S.; Harris, L.N.; Szallasi, Z. A signature of chromosomal instability inferred from gene expression profiles predicts clinical outcome in multiple human cancers. Nat. Genet. 2006, 38, 1043-1048. [CrossRef]

300. Buccitelli, C.; Salgueiro, L.; Rowald, K.; Sotillo, R.; Mardin, B.R.; Korbel, J.O. Pan-cancer analysis distinguishes transcriptional changes of aneuploidy from proliferation. Genome Res. 2017, 27, 501-511. [CrossRef]

301. Zhang, W.; Klinkebiel, D.; Barger, C.J.; Pandey, S.; Guda, C.; Miller, A.; Akers, S.N.; Odunsi, K.; Karpf, A.R. Global DNA Hypomethylation in Epithelial Ovarian Cancer: Passive Demethylation and Association with Genomic Instability. Cancers 2020, 12, 764. [CrossRef]

302. Karpf, A.R.; Matsui, S.-i. Genetic Disruption of Cytosine DNA Methyltransferase Enzymes Induces Chromosomal Instability in Human Cancer Cells. Cancer Res. 2005, 65, 8635-8639. [CrossRef]

303. Eden, A.; Gaudet, F.; Waghmare, A.; Jaenisch, R. Chromosomal Instability and Tumors Promoted by DNA Hypomethylation. Science 2003, 300, 455. [CrossRef]

304. Gemenetzidis, E.; Bose, A.; Riaz, A.M.; Chaplin, T.; Young, B.D.; Ali, M.; Sugden, D.; Thurlow, J.K.; Cheong, S.-C.; Teo, S.-H.; et al FOXM1 Upregulation Is an Early Event in Human Squamous Cell Carcinoma and it Is Enhanced by Nicotine during Malignant Transformation. PLoS ONE 2009, 4, e4849. [CrossRef] [PubMed] 
305. Teh, M.-T.; Gemenetzidis, E.; Patel, D.; Tariq, R.; Nadir, A.; Bahta, A.W.; Waseem, A.; Hutchison, I.L. FOXM1 Induces a Global Methylation Signature That Mimics the Cancer Epigenome in Head and Neck Squamous Cell Carcinoma. PLoS ONE 2012, 7, e34329. [CrossRef] [PubMed]

306. Teh, M.-T.; Gemenetzidis, E.; Chaplin, T.; Young, B.D.; Philpott, M.P. Upregulation of FOXM1 induces genomic instability in human epidermal keratinocytes. Mol. Cancer 2010, 9, 45. [CrossRef] [PubMed]

307. Zeman, M.K.; Cimprich, K.A. Causes and consequences of replication stress. Nat. Cell Biol. 2014, 16, 2-9. [CrossRef] [PubMed]

308. Merchut-Maya, J.M.; Bartek, J.; Maya-Mendoza, A. Regulation of replication fork speed: Mechanisms and impact on genomic stability. DNA Repair 2019, 81, 102654. [CrossRef] [PubMed]

309. Li, Z.; Yu, D.S.; Doetsch, P.W.; Werner, E. Replication stress and FOXM1 drive radiation induced genomic instability and cell transformation. PLoS ONE 2020, 15, e0235998. [CrossRef]

310. Kyuno, T.; Kohno, T.; Konno, T.; Yamaguchi, H.; Kyuno, D.; Imamura, M.; Kimura, Y.; Kojima, T.; Takemasa, I. Glucose-Dependent FOXM1 Promotes Epithelial-to-Mesenchymal Transition Via Cellular Metabolism and Targeting Snail in Human Pancreatic Cancer. Pancreas 2020, 49, 273-280. [CrossRef]

311. Cui, J.; Shi, M.; Xie, D.; Wei, D.; Jia, Z.; Zheng, S.; Gao, Y.; Huang, S.; Xie, K. FOXM1 Promotes the Warburg Effect and Pancreatic Cancer Progression via Transactivation of LDHA Expression. Clin. Cancer Res. 2014, 20, 2595-2606. [CrossRef] [PubMed]

312. Jiang, W.; Zhou, F.; Li, N.; Li, Q.; Wang, L. FOXM1-LDHA signaling promoted gastric cancer glycolytic phenotype and progression. Int. J. Clin. Exp. Pathol. 2015, 8, 6756-6763. [PubMed]

313. Shang, R.; Pu, M.; Li, Y.; Wang, D. FOXM1 regulates glycolysis in hepatocellular carcinoma by transactivating glucose transporter 1 expression. Oncol. Rep. 2017, 37, 2261-2269. [CrossRef] [PubMed]

314. Bala, B.R.K.; Katragunta, K.; Sarma, U.M.; Jain, N. Abundance of d-2-hydroxyglutarate in G2/M is determined by FOXM1 in mutant IDH1-expressing cells. FEBS Lett. 2019, 593, 2177-2193. [CrossRef]

315. Zand, B.; Previs, R.A.; Zacharias, N.M.; Rupaimoole, R.; Mitamura, T.; Nagaraja, A.; Guindani, M.; Dalton, H.J.; Yang, L.; Baddour, J.; et al. Role of Increased n-acetylaspartate Levels in Cancer. J. Natl. Cancer Inst. 2016, 108, djv426. [CrossRef]

316. Wang, Y.; Yun, Y.; Wu, B.; Wen, L.; Wen, M.; Yang, H.; Zhao, L.; Liu, W.; Huang, S.; Wen, N.; et al. FOXM1 promotes reprogramming of glucose metabolism in epithelial ovarian cancer cells via activation of GLUT1 and HK2 transcription. Oncotarget 2016, 7, 47985-47997. [CrossRef]

317. Abdel-Wahab, A.F.; Mahmoud, W.; Al-Harizy, R.M. Targeting glucose metabolism to suppress cancer progression: Prospective of anti-glycolytic cancer therapy. Pharmacol. Res. 2019, 150, 104511. [CrossRef]

318. Intlekofer, A.M.; Finley, L.W.S. Metabolic signatures of cancer cells and stem cells. Nat. Metab. 2019, 1, 177-188. [CrossRef]

319. Koundouros, N.; Poulogiannis, G. Reprogramming of fatty acid metabolism in cancer. Br. J. Cancer 2020, 122, 4-22. [CrossRef]

320. Park, H.J.; Gusarova, G.; Wang, Z.; Carr, J.R.; Li, J.; Kim, K.-H.; Qiu, J.; Park, Y.-D.; Williamson, P.R.; Hay, N.; et al. Deregulation of FoxM1b leads to tumour metastasis. EMBO Mol. Med. 2011, 3, 21-34. [CrossRef]

321. Chen, Y.; Ruben, E.A.; Rajadas, J.; Teng, N.N. In silico investigation of FOXM1 binding and novel inhibitors in epithelial ovarian cancer. Bioorganic Med. Chem. 2015, 23, 4576-4582. [CrossRef] [PubMed]

322. Lam, A.; Ngan, A.; Leung, M.-H.; Kwok, D.; Liu, V.; Chan, D.; Leung, W.Y.; Yao, K.-M. FOXM1b, which is present at elevated levels in cancer cells, has a greater transforming potential than FOXM1c. Front. Oncol. 2013, 3, 11. [PubMed]

323. Dai, J.; Yang, L.; Wang, J.; Xiao, Y.; Ruan, Q. Prognostic Value of FOXM1 in Patients with Malignant Solid Tumor: A Meta-Analysis and System Review. Dis. Markers 2015, 2015, 1-10. [CrossRef] [PubMed]

324. Li, L.; Wu, D.; Yu, Q.; Li, L.; Wu, P. Prognostic value of FOXM1 in solid tumors: A systematic review and meta-analysis. Oncotarget 2017, 8, 32298-32308. [CrossRef]

325. Engqvist, H.; Parris, T.Z.; Kovács, A.; Rönnerman, E.W.; Sundfeldt, K.; Karlsson, P.; Helou, K. Validation of Novel Prognostic Biomarkers for Early-Stage Clear-Cell, Endometrioid and Mucinous Ovarian Carcinomas Using Immunohistochemistry. Front. Oncol. 2020, 10, 162. [CrossRef]

326. Hughes, P.; Marshall, D.; Reid, Y.; Parkes, H.; Gelber, C. The costs of using unauthenticated, over-passaged cell lines: How much more data do we need? Biotechniques 2007, 43, 575-586. [CrossRef]

327. Ben-David, U.; Siranosian, B.; Ha, G.; Tang, H.; Oren, Y.; Hinohara, K.; Strathdee, C.A.; Dempster, J.; Lyons, N.J.; Burns, R.; et al. Genetic and transcriptional evolution alters cancer cell line drug response. Nature 2018, 560, 325-330. [CrossRef]

328. Zakarya, R.; Howell, V.M.; Colvin, E.K. Modelling Epithelial Ovarian Cancer in Mice: Classical and Emerging Approaches. Int. J. Mol. Sci. 2020, 21, 4806. [CrossRef]

329. Burger, R.A.; Brady, M.F.; Bookman, M.A.; Fleming, G.F.; Monk, B.J.; Huang, H.; Mannel, R.S.; Homesley, H.D.; Fowler, J.; Greer, B.E.; et al. Incorporation of Bevacizumab in the Primary Treatment of Ovarian Cancer. N. Engl. J. Med. 2011, 365, $2473-2483$. [CrossRef]

330. Perren, T.J.; Swart, A.M.; Pfisterer, J.; Ledermann, J.A.; Pujade-Lauraine, E.; Kristensen, G.; Carey, M.S.; Beale, P.; Cervantes, A.; Kurzeder, C.; et al. A Phase 3 Trial of Bevacizumab in Ovarian Cancer. N. Engl. J. Med. 2011, 365, 2484-2496. [CrossRef] [PubMed]

331. Pearce, O.M.; Delaine-Smith, R.M.; Maniati, E.; Nichols, S.; Wang, J.; Böhm, S.; Rajeeve, V.; Ullah, D.; Chakravarty, P.; Jones, R.R.; et al. Deconstruction of a Metastatic Tumor Microenvironment Reveals a Common Matrix Response in Human Cancers. Cancer Discov. 2018, 8, 304-319. [CrossRef] 
332. Cheon, D.-J.; Tong, Y.; Sim, M.-S.; Dering, J.; Berel, D.; Cui, X.; Lester, J.; Beach, J.A.; Tighiouart, M.; Walts, A.E.; et al. A Collagen-Remodeling Gene Signature Regulated by TGF- $\beta$ Signaling Is Associated with Metastasis and Poor Survival in Serous Ovarian Cancer. Clin. Cancer Res. 2014, 20, 711-723. [CrossRef] [PubMed]

333. Yeung, T.-L.; Leung, C.S.; Wong, K.-K.; Samimi, G.; Thompson, M.S.; Liu, J.; Zaid, T.M.; Ghosh, S.; Birrer, M.J.; Mok, S.C. TGF- $\beta$ Modulates Ovarian Cancer Invasion by Upregulating CAF-Derived Versican in the Tumor Microenvironment. Cancer Res. 2013, 73, 5016-5028. [CrossRef]

334. Turner, T.B.; Buchsbaum, D.J.; Straughn, J.M.; Randall, T.D.; Arend, R.C. Ovarian cancer and the immune system-The role of targeted therapies. Gynecol. Oncol. 2016, 142, 349-356. [CrossRef] [PubMed]

335. Zhang, L.; Conejo-Garcia, J.R.; Katsaros, D.; Gimotty, P.A.; Massobrio, M.; Regnani, G.; Makrigiannakis, A.; Gray, H.; Schlienger, K.; Liebman, M.N.; et al. Intratumoral T Cells, Recurrence, and Survival in Epithelial Ovarian Cancer. N. Engl. J. Med. 2003, 348, 203-213. [CrossRef] [PubMed]

336. Sato, E.; Olson, S.H.; Ahn, J.; Bundy, B.; Nishikawa, H.; Qian, F.; Jungbluth, A.A.; Frosina, D.; Gnjatic, S.; Ambrosone, C.; et al. Intraepithelial $\mathrm{CD}^{+}$tumor-infiltrating lymphocytes and a high $\mathrm{CD} 8^{+} /$regulatory $\mathrm{T}$ cell ratio are associated with favorable prognosis in ovarian cancer. Proc. Natl. Acad. Sci. USA 2005, 102, 18538-18543. [CrossRef]

337. Odunsi, K.; Matsuzaki, J.; James, S.R.; Mhawech-Fauceglia, P.; Tsuji, T.; Miller, A.; Zhang, W.; Akers, S.N.; Griffiths, E.A.; Miliotto, A.; et al. Epigenetic Potentiation of NY-ESO-1 Vaccine Therapy in Human Ovarian Cancer. Cancer Immunol. Res. 2014, 2, 37-49. [CrossRef]

338. Sehouli, J.; Senyuva, F.; Fotopoulou, C.; Neumann, U.; Denkert, C.; Werner, L.; Gülten, O. Özcelik Intra-abdominal tumor dissemination pattern and surgical outcome in 214 patients with primary ovarian cancer. J. Surg. Oncol. 2009, 99, 424-427. [CrossRef]

339. Gerber, S.A.; Rybalko, V.Y.; Bigelow, C.E.; Lugade, A.A.; Foster, T.H.; Frelinger, J.G.; Lord, E.M. Preferential Attachment of Peritoneal Tumor Metastases to Omental Immune Aggregates and Possible Role of a Unique Vascular Microenvironment in Metastatic Survival and Growth. Am. J. Pathol. 2006, 169, 1739-1752. [CrossRef]

340. Flesken-Nikitin, A.; Choi, K.-C.; Eng, J.P.; Shmidt, E.N.; Nikitin, A.Y. Induction of Carcinogenesis by Concurrent Inactivation of p53 and $\mathbf{R} \boldsymbol{b} \mathbf{1}$ in the Mouse Ovarian Surface Epithelium. Cancer Res. 2003, 63, 3459-3463.

341. Emerling, B.M.; Weinberg, F.; Liu, J.-L.; Mak, T.W.; Chandel, N.S. PTEN regulates p300-dependent hypoxia-inducible factor 1 transcriptional activity through Forkhead transcription factor 3a (FOXO3a). Proc. Natl. Acad. Sci. USA 2008, 105, 2622-2627. [CrossRef]

342. Mishra, R.; Hanker, A.; Garrett, J.T. Genomic alterations of ERBB receptors in cancer: Clinical implications. Oncotarget 2017, 8, 114371-114392. [CrossRef]

343. Lam, E.W.-F.; Francis, R.E.; Myatt, S.S.; Krol, J.; Hartman, J.; Peck, B.; McGovern, U.B.; Wang, J.; Guest, S.K.; Filipovic, A.; et al. FoxM1 is a downstream target and marker of HER2 overexpression in breast cancer. Int. J. Oncol. 2009, 35, 57-68. [CrossRef]

344. Momeny, M.; Zarrinrad, G.; Moghaddaskho, F.; Poursheikhani, A.; Sankanian, G.; Zaghal, A.; Mirshahvaladi, S.; Esmaeili, F.; Eyvani, H.; Barghi, F.; et al. Dacomitinib, a pan-inhibitor of ErbB receptors, suppresses growth and invasive capacity of chemoresistant ovarian carcinoma cells. Sci. Rep. 2017, 7, 1-12. [CrossRef]

345. Momeny, M.; Esmaeili, F.; Hamzehlou, S.; Yousefi, H.; Javadikooshesh, S.; Vahdatirad, V.; Alishahi, Z.; Mousavipak, S.H.; Bashash, D.; Dehpour, A.R.; et al. The ERBB receptor inhibitor dacomitinib suppresses proliferation and invasion of pancreatic ductal adenocarcinoma cells. Cell. Oncol. 2019, 42, 491-504. [CrossRef] [PubMed]

346. Huang, C.; Du, J.; Xie, K. FOXM1 and its oncogenic signaling in pancreatic cancer pathogenesis. Biochim. et Biophys. Acta (BBA)-Bioenerg. 2014, 1845, 104-116. [CrossRef] [PubMed]

347. Noack, S.; Raab, M.; Matthess, Y.; Sanhaji, M.; Kramer, A.; Győrffy, B.; Kaderali, L.; El-Balat, A.; Becker, S.; Strebhardt, K. Synthetic lethality in CCNE1-amplified high grade serous ovarian cancer through combined inhibition of Polo-like kinase 1 and microtubule dynamics. Oncotarget 2018, 9, 25842-25859. [CrossRef] [PubMed]

348. Schöffski, P.; Blay, J.-Y.; De Greve, J.; Brain, E.; Machiels, J.-P.; Soria, J.-C.; Sleijfer, S.; Wolter, P.; Ray-Coquard, I.; Fontaine, C.; et al. Multicentric parallel phase II trial of the polo-like kinase 1 inhibitor BI 2536 in patients with advanced head and neck cancer, breast cancer, ovarian cancer, soft tissue sarcoma and melanoma. The first protocol of the European Organization for Research and Treatment of Cancer (EORTC) Network of Core Institutes (NOCI). Eur. J. Cancer 2010, 46, 2206-2215. [CrossRef]

349. Demeure, M.J.; Armaghany, T.; Ejadi, S.; Ramanathan, R.K.; Elfiky, A.; Strosberg, J.R.; Smith, D.C.; Whitsett, T.; Liang, W.S.; Sekar, S.; et al. A phase I/II study of TKM-080301, a PLK1-targeted RNAi in patients with adrenocortical cancer (ACC). J. Clin. Oncol. 2016, 34, 2547. [CrossRef]

350. Sun, L.; Ren, X.; Wang, I.-C.; Pradhan, A.; Zhang, Y.; Flood, H.; Han, B.; Whitsett, J.A.; Kalin, T.V.; Kalinichenko, V.V. The FOXM1 inhibitor RCM-1 suppresses goblet cell metaplasia and prevents IL-13 and STAT6 signaling in allergen-exposed mice. Sci. Signal. 2017, 10, eaai8583. [CrossRef] [PubMed]

351. Hegde, N.S.; Sanders, D.A.; Rodriguez, R.; Balasubramanian, S. The transcription factor FOXM1 is a cellular target of the natural product thiostrepton. Nat. Chem. 2011, 3, 725-731. [CrossRef]

352. Radhakrishnan, S.; Bhat, U.G.; Hughes, D.E.; Wang, I.-C.; Costa, R.H.; Gartel, A.L. Identification of a Chemical Inhibitor of the Oncogenic Transcription Factor Forkhead Box M1. Cancer Res. 2006, 66, 9731-9735. [CrossRef]

353. Wang, M.; Gartel, A.L. Micelle-Encapsulated Thiostrepton as an Effective Nanomedicine for Inhibiting Tumor Growth and for Suppressing FOXM1 in Human Xenografts. Mol. Cancer Ther. 2011, 10, 2287-2297. [CrossRef] [PubMed] 
354. Gartel, A.L. Thiazole Antibiotics Siomycin a and Thiostrepton Inhibit the Transcriptional Activity of FOXM1. Front. Oncol. 2013, 3, 150. [CrossRef] [PubMed]

355. Halasi, M.; Pandit, B.; Wang, M.; Nogueira, V.; Hay, N.; Gartel, A.L. Combination of Oxidative Stress and FOXM1 Inhibitors Induces Apoptosis in Cancer Cells and Inhibits Xenograft Tumor Growth. Am. J. Pathol. 2013, 183, 257-265. [CrossRef]

356. Ketola, K.; Munuganti, R.S.; Davies, A.; Nip, K.M.; Bishop, J.L.; Zoubeidi, A. Targeting Prostate Cancer Subtype 1 by Forkhead Box M1 Pathway Inhibition. Clin. Cancer Res. 2017, 23, 6923-6933. [CrossRef]

357. Kim, S.-H.; Kim, K.-Y.; Yu, S.-N.; Park, S.-G.; Yu, H.-S.; Seo, Y.-K.; Ahn, S.-C. Monensin Induces PC-3 Prostate Cancer Cell Apoptosis via ROS Production and $\mathrm{Ca}^{2+}$ Homeostasis Disruption. Anticancer. Res. 2016, 36, 5835-5843.

358. Nagaraju, G.P.; Zafar, S.F.; El-Rayes, B.F. Pleiotropic effects of genistein in metabolic, inflammatory, and malignant diseases. Nutr Rev. 2013, 71, 562-572. [CrossRef]

359. Wang, Z.; Ahmad, A.; Banerjee, S.; Azmi, A.; Kong, D.; Li, Y.; Sarkar, F.H. FoxM1 is a Novel Target of a Natural Agent in Pancreatic Cancer. Pharm. Res. 2010, 27, 1159-1168. [CrossRef]

360. Cao, J.; Ning, Y.; Li, Q.; Xiang, H.; Liu, F. Apoptosis induced by 7-difluoromethoxyl-5,4'-di-n-octyl genistein via the inactivation of FoxM1 in ovarian cancer cells. Oncol. Rep. 2012, 27, 1857-1864. [CrossRef] [PubMed]

361. Cao, X.; Ren, K.; Song, Z.; Li, D.; Quan, M.; Zheng, Y.; Cao, J.; Zeng, W.; Zou, H. 7-Difluoromethoxyl-5,4'-di-n-octyl genistein inhibits the stem-like characteristics of gastric cancer stem-like cells and reverses the phenotype of epithelial-mesenchymal transition in gastric cancer cells. Oncol. Rep. 2016, 36, 1157-1165. [CrossRef]

362. Gormally, M.; Dexheimer, T.S.; Marsico, G.; Sanders, D.A.; Lowe, C.; Matak-Vinković, D.; Michael, S.; Jadhav, A.; Rai, G.; Maloney, D.J.; et al. Suppression of the FOXM1 transcriptional programme via novel small molecule inhibition. Nat. Commun. 2014, 5, 1-11. [CrossRef]

363. Xiang, Q.; Tan, G.; Jiang, X.; Wu, K.; Tan, W.; Tan, Y. Suppression of FOXM1 Transcriptional Activities via a Single-Stranded DNA Aptamer Generated by SELEX. Sci. Rep. 2017, 7, 45377. [CrossRef]

364. Ziegler, Y.; Laws, M.J.; Guillen, V.S.; Kim, S.H.; Dey, P.; Smith, B.P.; Gong, P.; Bindman, N.; Zhao, Y.; Carlson, K.; et al. Suppression of FOXM1 activities and breast cancer growth in vitro and in vivo by a new class of compounds. NPJ Breast Cancer 2019, 5, 1-11. [CrossRef] [PubMed]

365. Lee, D.W.; Lee, W.; Kwon, M.; Lee, H.N. Dual inhibition of FOXM1 and its compensatory signaling pathway decreased the survival of ovarian cancer cells. Oncol. Rep. 2020, 45, 390-400. [CrossRef] [PubMed]

366. Ning, Y.; Xu, M.; Cao, X.; Chen, X.; Luo, X. Inactivation of AKT, ERK and NF-кB by genistein derivative, 7-difluoromethoxyl-5,4'di-n-octylygenistein, reduces ovarian carcinoma oncogenicity. Oncol. Rep. 2017, 38, 949-958. [CrossRef] [PubMed]

367. Branigan, T.B.; Kozono, D.; Schade, A.E.; Deraska, P.; Rivas, H.G.; Sambel, L.; Reavis, H.D.; Shapiro, G.I.; D'Andrea, A.D.; DeCaprio, J.A. MMB-FOXM1-driven premature mitosis is required for CHK1 inhibitor sensitivity. Cell Rep. 2021, $34,108808$. [CrossRef]

368. Diab, A.; Gem, H.; Swanger, J.; Kim, H.Y.; Smith, K.; Zou, G.; Raju, S.; Kao, M.; Fitzgibbon, M.; Loeb, K.R.; et al. FOXM1 drives HPV+ HNSCC sensitivity to WEE1 inhibition. Proc. Natl. Acad. Sci. USA 2020, 117, 28287-28296. [CrossRef]

369. Chung, S.; Vail, P.J.; Witkiewicz, A.K.; Knudsen, E.S. Coordinately Targeting Cell-Cycle Checkpoint Functions in Integrated Models of Pancreatic Cancer. Clin. Cancer Res. 2019, 25, 2290-2304. [CrossRef] [PubMed]

370. Bushweller, J.H. Targeting transcription factors in cancer-from undruggable to reality. Nat. Rev. Cancer 2019, 19, 611-624. [CrossRef]

371. van den Brand, D.; Mertens, V.; Massuger, L.F.A.G.; Brock, R. siRNA in ovarian cancer-Delivery strategies and targets for therapy. J. Control. Release 2018, 283, 45-58. [CrossRef]

372. Zhang, W.; Liu, Y.; Zhou, X.; Zhao, R.; Wang, H. Applications of CRISPR-Cas9 in gynecological cancer research. Clin. Genet. 2020, 97, 827-834. [CrossRef] [PubMed]

373. Áyen, Á.; Martínez, Y.J.; Marchal, J.A.; Boulaiz, H. Recent Progress in Gene Therapy for Ovarian Cancer. Int. J. Mol. Sci. 2018, 19, 1930. [CrossRef] [PubMed] 